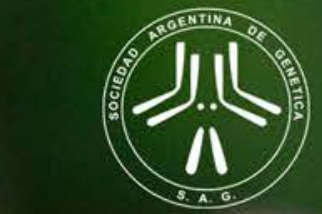

December 2019

Volumen $\mathbf{X X X}$

No. 2

E-ISNN: 1852-6322
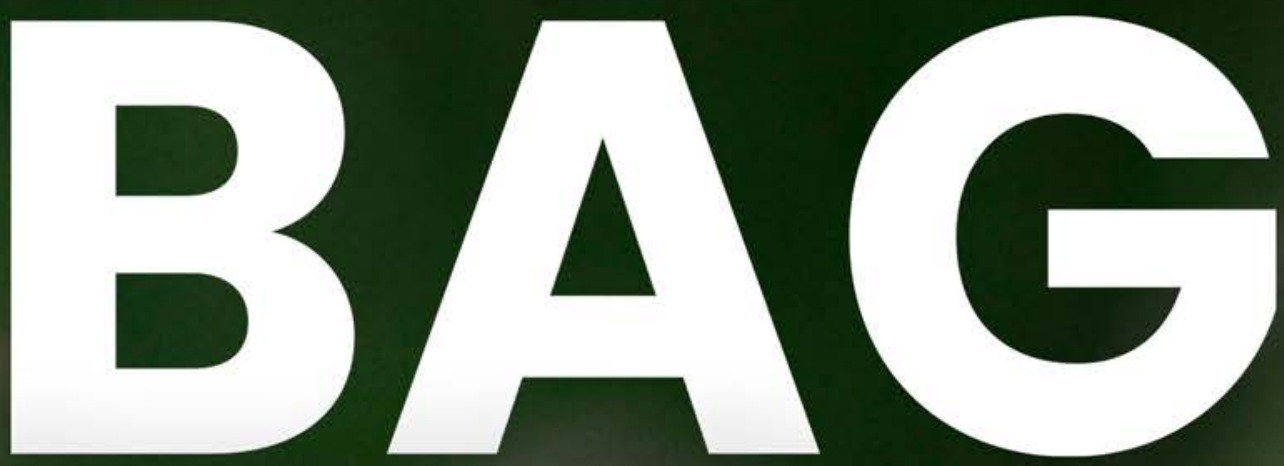

\title{
Journal of Basic \& Applied Genetics
}

Journal of the Argentine Society of Genetics Revista de la Sociedad Argentina de Genética www.sag.org.ar/jbag

Buenos Aires, Argentina 


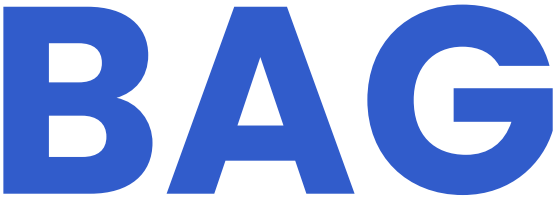

V. XXX - No.2

\section{Journal of Basic \& Applied Genetics}

December 2019

Included in:
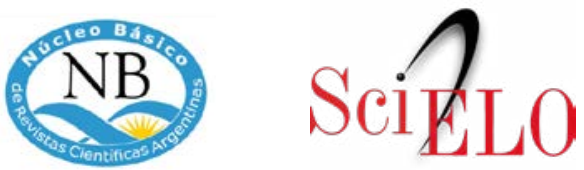

Cited by: 


\section{Comité Editorial}

\section{Editor General:}

\section{Dra. Elsa L. Camadro}

Facultad de Ciencias Agrarias

Universidad Nacional de Mar del Plata

Consejo Nacional de Investigaciones

Científicas y Técnicas

Balcarce, Argentina

camadro.elsa@inta.gob.ar

\section{Editores Asociados:}

Citogenética Animal

\section{Dra. Liliana M. Mola}

Departamento de Ecología, Genética y

Evolución

Facultad de Ciencias Exactas y Naturales

Universidad Nacional de Buenos Aires

Consejo Nacional de Investigaciones

Científicas y Técnicas

Buenos Aires, Argentina

limola@ege.fcen.uba.ar; lilimola@yahoo.com.ar

Citogenética Vegetal

\section{Dr. Julio R. Daviña}

Instituto de Biologia Subtropical

Universidad Nacional de Misiones

Posadas, Argentina

juliordavina@fceqyn.unam.edu.ar

Genética de Poblaciones y Evolución

\section{Dr. Jorge Cladera}

Instituto de Genética "Ewald A. Favret"

Centro de Investigación en Ciencias

Veterinarias y Agronómicas

Instituto Nacional de Tecnología Agropecuaria

Castelar, Argentina

cladera.jorge@inta.gob.ar

Dra. Noemí Gardenal

Facultad de Ciencias Exactas, Físicas y

Naturales

Universidad Nacional de Córdoba

Consejo Nacional de Investigaciones

Científicas y Técnicas

Córdoba, Argentina

ngardenal@unc.edu.ar

\section{Dr. Juan César Vilardi}

Departamento de Ecología, Genética y

Evolución

Facultad de Ciencias Exactas y Naturales

Universidad Nacional de Buenos Aires

Consejo Nacional de Investigaciones

Científicas y Técnicas

Buenos Aires, Argentina

vilardi@bg.fcen.uba.ar

Genética Humana, Médica y Citogenética

Dra. Silvia Adela Ávila

Hospital Castro Rendón

Universidad Nacional del Comahue

Nuequén, Argentina

silvia347@gmail.com

\section{Dra. María Inés Echeverría}

Instituto de Genética

Facultad de Ciencias Médicas

Universidad Nacional de Cuyo

Mendoza, Argentina

miecheve@fcm.uncu.edu.ar

Dra. María Purificación Galindo Villardón

Facultad Medicina, Campus Miguel de

Unamuno.

Universidad de Salamanca.

Salamanca, España

pgalindo@usal.es
Dr. Santiago Lippold

Centro de Educación Médica e Investigaciones

Clínicas

Buenos Aires, Argentina

sell@fibertel.com.ar

\section{Dr. José Arturo Prada Oliveira}

Facultad de Medicina. Departamento de

Anatomía Humana y Embriología

Universidad de Cádiz.

Cádiz, España

arturo.prada@uca.es

Genética Molecular (Animal)

Dr. Guillermo Giovambattista

Instituto de Genética Veterinaria

Facultad de Ciencias Veterinarias

Universidad Nacional de La Plata

Consejo Nacional de Investigaciones

Científicas y Técnicas

La Plata, Argentina

ggiovam@fcv.unlp.edu.ar

Genética Molecular (Vegetal)

\section{Dr. Alberto Acevedo}

Centro de Investigación de Recursos Naturales Instituto Nacional de Tecnología Agropecuaria

Castelar, Argentina

acevedo.alberto@inta.gob.ar

\section{Dr. Andrés Zambell}

Fac. de Ciencias Agrarias, Universidad

Nacional

de Mar del Plata.

Balcarce, Argentina

andres.d.zambelli@gmail.com

Genética y Mejoramiento Animal

Dra. Liliana A. Picardi

Facultad de Ciencias Agrarias

Universidad Nacional de Rosario

Zavalla, Argentina

Ipicardi@fcagr.unr.edu.ar

Dra. María Inés Oyarzábal

Facultad de Ciencias Veterinarias

Universidad Nacional de Rosario

Rosario, Argentina

moyazabr@unr.edu.ar

Genética y Mejoramiento Genético Vegetal

Dra. Natalia Bonamico

Facultad de Agronomía y Veterinaria

Universidad Nacional de Río Cuarto

Río Cuarto, Argentina

nbonamico@ayv.unrc.edu.ar

\section{Dr. José Crossa}

Unidad de Biometría y Estadística

Centro Internacional de Mejoramiento de Maíz

y Trigo (CIMMYT)

México, D.F., México

j.crossa@cgiar.org

\section{Dr. Ricardo W. Masuelli}

Facultad de Ciencias Agrarias

Universidad Nacional de Cuyo

Consejo Nacional de Investigaciones

Científicas y Técnicas

Mendoza, Argentina

rmasuelli@fca.uncu.edu.ar

\section{Dr. Rodomiro Ortiz}

Department of Plant Breeding

Swedish University of Agricultural Science

Uppsala, Suecia

rodomiro.ortiz@slu.se
Dra. Mónica Poverene

Departamento de Agronomía

Universidad Nacional del Sur

Bahía Blanca, Argentina

poverene@criba.edu.ar

Mutagénesis

Dr. Alejandro D. Bolzán

Laboratorio de Citogenética y Mutagénesis

Instituto Multidisciplinario de Biología Celular

Consejo Nacional de Investigaciones

Científicas y Técnicas

La Plata, Argentina

abolzan@imbice.gov.ar

Mutaciones Inducidas en Mejoramiento

Vegetal

Ing. Agr. (M.Sc.) Alberto R.Prina

Instituto de Genética "Ewald A. Favret"

Centro de Investigación en Ciencias

Veterinarias y Agronómicas

Instituto Nacional de Tecnología Agropecuaria

Castelar, Argentina

prina.albertoraul@inta.gob.ar

\section{Consultor Estadístico:}

Dr. David Almorza

Facultad de Ciencias del Trabajo,

Departamento

de Estadística e Investigación Operativa

Universidad de Cádiz.

Cádiz, España

david.almorza@uca.es

Ing. Agr. Francisco J. Babinec

Estación Experimental Agropecuaria Angui

Instituto Nacional de Tecnología Agropecuaria

Facultad de Agronomía

Universidad Nacional de La Pampa

Santa Rosa, Argentina

babinec.francisco@inta.gob.ar

Secretaria de Redacción:

Dra. María de las Mercedes Echeverría

Facultad de Ciencias Agrarias

Universidad Nacional de Mar del Plata

Balcarce, Argentina

echeverria.maria@inta.gob.ar

Diseño y maquetación:

Mauro Salerno

maurosalerno92@gmail.com

Corrección de estilo:

Dr. Mariano Santin

marianosantini@yahoo.com.ar
Imágen de tapa:

Mis amigos del jardín

Autora: A. Soledad Firpo 


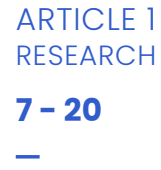

MOLECULAR MARKER ANALYSIS OF SPIKE FERTILITY INDEX AND RELATED TRAITS IN A BREAD WHEAT RECOMBINANT INBRED LINE POPULATION

ANÁLISIS DE MARCADORES MOLECULARES PARA EL ÍNDICE DE FERTILIDAD DE ESPIGA Y CARACTERES ASOCIADOS EN UNA POBLACIÓN DE LIINEAS ENDOCRIADAS RECOMBINANTES DE TRIGO PAN.

Panelo J.S. , Alonso M.P., Mirabella N.E. , Pontaroli A.C.

KARYOLOGICAL STUDY IN THE CHILEAN RHATANY Krameria cistoidea HOOK. \& ARN. (KRAMERIACEAE) ESTUDIO CARIOLÓGICO EN EL PACUL CHILENO Krameria cistoidea HOOK. \& ARN. (KRAMERIACEAE)

Palma Rojas C., Jara Seguel P., García M., von Brand E., Araya Jaime C.

TP53 PATHOGENIC VARIANTS RELATED TO CANCER VARIANTES PATOGÉNICAS DE TP53 RELACIONADAS CON CÁNCER Rosero C.Y., Mejia L.G., Corredor M.

THE HUMAN VARIOME PROJECT COUNTRY NODE OF ARGENTINA IN THE FIRST TWO YEARS OF ACTIVITY: PAST, PRESENT AND FUTURE EL NODO ARGENTINO DEL PROYECTO VARIOMA HUMANO EN LOS PRIMEROS DOS AÑOS DE ACTIVIDAD: PASADO, PRESENTE Y FUTURO

Solano A.R., Garrido M., Mele P.G., Podestá E.J., Reichardt J.K.V.

GENOME SIZE IN THREE SPECIES OF Glandularia AND THEIR HYBRIDS TAMAÑO DEL GENOMA EN TRES ESPECIES DE Glandularia Y SUS HÍBRIDOS

Ferrari M.R., Greizerstein E.J., Poggio L.

DR. ROBERTO COCO

CONGRESO ALAG 2019. 6 AL 9 DE OCTUBRE. MENDOZA, ARGENTINA. RESÚMENES OMITIDOS MODIFICACIONES SOLICITADAS POR LOS AUTORES EN RESÚMENES PUBLICADOS 



\title{
MOLECULAR MARKER ANALYSIS OF SPIKE FERTILITY INDEX AND RELATED TRAITS IN A BREAD WHEAT RECOMBINANT INBRED LINE POPULATION
}

\author{
ANÁLISIS DE MARCADORES MOLECULARES PARA EL ÍNDICE DE \\ FERTILIDAD DE ESPIGA Y CARACTERES ASOCIADOS EN UNA POBLACIÓN \\ DE LIINEAS ENDOCRIADAS RECOMBINANTES DE TRIGO PAN.
}

\author{
Panelo J.S. ${ }^{1,2}$, Alonso M.P. ${ }^{1,3}$, Mirabella N.E. ${ }^{1}$, Pontaroli A.C. ${ }^{1,3 *}$
}

1 Unidad Integrada Balcarce (Estación Experimental Agropecuaria Balcarce, Instituto Nacional de Tecnología Agropecuaria - Facultad de Ciencias Agrarias, Universidad Nacional de Mar del Plata); CC 276 (7620) Balcarce, Argentina

${ }^{2}$ Comisión de Investigaciones Científicas de la Provincia de Buenos Aires; CC 276 (7620) Balcarce, Argentina.

${ }^{3}$ Consejo Nacional de Investigaciones Científicas y Técnicas; CC 276 (7620) Balcarce, Argentina.

Corresponding author: Ana Clara Pontaroli pontaroli.ana@inta.gob.ar

Cite this article as: Panelo J.S., Alonso M.P., Mirabella N.E., Pontaroli A.C. 2019. MOLECULAR MARKER ANALYSIS OF SPIKE FERTILITY INDEX AND RELATED TRAITS IN A BREAD WHEAT RECOMBINANT INBRED LINE POPULATION. BAG. Journal of Basic and Applied Genetics XXX (2): 7-20.

Received: 05/28/2019

Revised version received: 07/25/2019 Accepted: 08/13/2019

General Editor: Elsa Camadro DOI: 10.35407/bag.2019.xxx.02.01 ISSN online version: 1852-6233

Available online at www.sag.org.ar/jbag

\section{ABSTRACT}

Spike fertility index (SF) has been well established as an ecophysiological trait related to grain number per unit area and a promising selection target in wheat breeding programs. Scarce information on the molecular basis of SF is available thus far. In this study, a preliminary molecular marker analysis was carried out in a RIL population derived from the cross between two Argentinean cultivars with contrasting SF to identify candidate genomic regions associated with SF. Twenty-four microsatellites and two functional markers that had been found to co-segregate with $\mathrm{SF}$ in a bulked-segregant analysis of the $\mathrm{F}_{3}$ generation of the population were analyzed. Phenotypic data were collected from three field experiments carried out during 2013, 2014 and 2015 growing seasons at Balcarce, Argentina. Two genomic regions associated with $\mathrm{SF}$ in chromosomes $5 \mathrm{BS}$ and 7AS were detected, which merit further investigation.

Key words: selection, genomic regions, grain number, yield, QTL, spike fertility index, fruiting efficiency

\section{RESUMEN}

El índice de fertilidad de espiga (FE) ha sido propuesto como un carácter ecofisiológico asociado con el número de granos por unidad de área y como criterio de selección prometedor para los programas de mejoramiento de trigo. Sin embargo, la información sobre las bases moleculares de la FE aún es escasa. En este estudio, se realizó un análisis preliminar de marcadores moleculares en una población RIL derivada del cruce entre dos cultivares argentinos con $\mathrm{FE}$ contrastante con el objetivo de identificar regiones genómicas candidatas asociadas con el carácter. Se analizaron 24 microsatélites y dos marcadores funcionales que se había encontrado que se co-segregaban con la FE en un análisis de segregantes en "bulk" en la generación $\mathrm{F}_{3}$ de la población. Se recopilaron datos fenotípicos de tres experimentos de campo llevados a cabo durante las temporadas de cultivo 2013, 2014 y 2015 en Balcarce, Argentina. Se detectaron dos regiones genómicas asociadas con la FE en los cromosomas 5BS y 7AS, que mostraron ser estables a través de los años de evaluación. Este trabajo aporta información novedosa acerca de las bases moleculares de la $\mathrm{FE}$, las cuales deberán ser estudiadas con mayor profundidad.

Palabras clave: selección, regiones genómicas, número de granos, rendimiento, QTL, indice de fertilidad de espiga, eficiencia de fructificación

\footnotetext{
* This work is part of a thesis by M.P. Alonso in partial fulfillment of the requirements for the Doctor's degree (Facultad de Ciencias Agrarias, Universidad Nacional de Mar del Plata, Argentina). The authors contributed equally to this work (ex-aequo).
} 


\section{INTRODUCTION}

Bread wheat (Triticum aestivum L.) is one of the most important field crops in the world. It provides $\sim 20 \%$ of human food calories and protein (FAO 2018). Prospects indicate a steady growth in the global population, which will be encompassed by an increase in food demand. However, this demand will hardly be attained through the expansion of farming areas (Albajes et al. 2013). Breeding efforts should rather concentrate on achieving higher grain yield-increase rates (Reynolds et al. 2012).

Grain yield in wheat is more strongly associated with grain number per unit area (hereinafter referred to as $\mathrm{GN} \mathrm{m}^{-2}$ ) than it is with grain weight (Sadras 2007; Fischer 2011). Hence, breeding efforts have focused on increasing grain yield through increasing $\mathrm{GN} \mathrm{m}^{-2}$ (Slafer et al. 2014, 2015; Lo Valvo et al. 2018). However, this is a difficult trait to select for in early breeding stages. Thus, the use of $\mathrm{GN} \mathrm{m}^{-2}$-related traits as selection targets may be helpful to increase grain yield at the pace it is required (Slafer 2003; Fischer and Rebetzke 2018). A conceptual model proposed by Fischer (1984) suggests that, under non-limiting growing conditions, $\mathrm{GN} \mathrm{m}^{-2}$ in wheat can be considered as the product of (i) the duration of the spike growth period, (ii) the crop growth rate during the spike growth period, (iii) the dry weight partitioning to spikes during the spike growth period and (iv) the number of grains per unit of spike chaff dry weight, i.e. a spike fertility index (SF), also termed "fruiting efficiency" (Ferrante et al. 2012).

Many authors have described SF as an ecophysiological component which explains a substantial proportion of the differences in $\mathrm{GN} \mathrm{m}^{-2}$ between cultivars (Acreche et al. 2008; Gonzalez et al. 2014; Aisawi et al. 2015; Gonzalez-Navarro et al. 2016), with high stability across environments (Abbate et al. 2013; Elía et al. 2016; Guo et al. 2016) and moderate to high heritability (Martino et al. 2015; Mirabella et al. 2016; Alonso et al. 2018b). In turn, a fast and high-throughput method was developed for SF determination at maturity, using as few as 15 spikes per plot (Abbate et al. 2013). Adding up all these features, SF emerges as a promising trait to select for in the early generations of breeding programs, in which little seed is available for $\mathrm{GN} \mathrm{m}^{-2}$ determinations (Fischer and Rebetzke 2018). Furthermore, a recent study showed that the use of SF as a selection criterion, either solely or in combination with selection for high yield, effectively increased yield, resulting in superior and more stable grain yields than selecting just for high yield (Alonso et al. 2018b).

Molecular markers associated with agronomically valuable traits have been successfully used to select for in wheat breeding programs' early generations (Collard and Mackill 2008). For example, some authors reported microsatellites linked to traits as plant height (Wang et al. 2010; Zhang et al. 2011), grain number per spike
(Quarrie et al. 2005, 2006; Hai et al. 2008) and yield per se (Kobiljski et al. 2007). The availability of molecular markers associated with SF would be very helpful for increasing the genetic gain per selection cycle. Markerassisted selection could allow seed or plantlet selection of transgressive genotypes at early generations of segregating populations, and molecular characterization of the crossing block. Despite the prospective relevance of SF for wheat breeding, about the genetic and molecular control of this trait little is known, except for a couple of recent studies which respectively reported a QTL for $\mathrm{SF}$ in chromosome $2 \mathrm{AL}$ (candidate gene $\mathrm{CO}_{4}$; Guo et al. 2017) and a significant effect of photoperiod sensitivity genes Ppd-B1 and Ppd-D1 on SF (Ramirez et al. 2018). In the present study, a preliminary molecular marker analysis was carried out in a recombinant inbred line (RIL) population segregating for SF in order to identify candidate genomic regions associated with this trait. These results provide valuable information as a first step in mapping QTL/genes controlling SF and possibly other related traits.

\section{MATERIALS AND METHODS}

\section{Phenotypic data generation}

In the present study, molecular marker analysis of $\mathrm{SF}$ and related traits was carried out with previously published phenotypic data (Alonso et al. 2018a, b). A brief description of the mapping population, experiments, environmental conditions, and measurements and calculations, is included below. For further details see Alonso et al. (2018a).

Plant material. A mapping population of 146 recombinant inbred lines (RILs) derived from the cross between the Argentinean spring bread wheat cultivars 'Baguette 10' and 'Klein Chajá' was used in all field experiments. Both parental cultivars were also included. 'Baguette 10' and 'Klein Chajá' were commercially released in 2000 and 2002 respectively and are contrasting for SF and other yield-related traits (Martino et al. 2015; Alonso et al. 2018a, b).

Field experiments. During the 2013, 2014 and 2015 crop seasons, field experiments were carried out at the experimental station of the Instituto Nacional de Tecnología Agropecuaria (INTA) Balcarce ( $37^{\circ} 45^{\prime} \mathrm{S} ; 55^{\circ}$ 18' W; 130 m a.s.l.), Balcarce, Buenos Aires, Argentina. Experiments are fully described in Alonso et al. (2018a, b).

Measurements and calculations. Plant height was measured from the ground to the ear tip at maturity; the average of two measurements per plot was registered. At the same time, a sample of 20 spikes was drawn at random from the three or five central rows of each plot and air-dried for further SF determination according to Abbate et al. (2013). Briefly, the sample was weighed (total weight) and threshed, and grains were weighed 
(grain weight) and counted (grain number). Spike fertility index was calculated as the quotient between grain number and chaff weight (i.e., the difference between total weight and grain weight).

Grain yield was determined by mechanical harvest. For grain weight determination, a clean and dry subsample of $\sim 30 \mathrm{~g}$ was taken from the yield sample, weighted and counted in an automatic counter. Grain number $\mathrm{m}^{-2}$ was calculated as the quotient between grain yield and grain weight. Grain test weight was measured using a Schopper cylinder.

\section{Molecular marker analysis}

Genomic DNA extraction from fresh tissue of ten-daysold seedling leaves was carried out according to Haymes et al. (1996). Approximately 200 molecular markers were analyzed for polymorphism between the parents of the RIL population. Bulked segregant analysis (Michelmore et al. 1991) was carried out in the $\mathrm{F}_{3}$ generation of the population (Deperi, 2012). Those markers which showed co-segregation with SF were used in the present study (24 microsatellites and two functional markers, Table 1, Fig. S1). In all cases, PCR reactions were performed using a final volume of $15 \mu \mathrm{l}$ in a Veriti ${ }^{\mathrm{TM}}$ (Applied Biosystems) thermal cycler. The reaction buffer contained $1 \mathrm{X}$ Taq DNA Polymerase buffer (Promega), o.8 U Taq DNA Polymerase (Promega), $0.2 \mathrm{mM}$ of each dNTP, $0.2 \mu \mathrm{M}$ of each primer, $1.5 \mathrm{mM}$ of $\mathrm{MgCl}_{2}$ and $100 \mathrm{ng}$ of genomic DNA (template). Cycling conditions were as follows: 3 ' initial denaturation at $95^{\circ} \mathrm{C}, 18$ cycles of $30^{\prime \prime}$ denaturation at $95^{\circ} \mathrm{C}, 30^{\prime \prime}$ annealing at $65^{\circ} \mathrm{C}$ to $56^{\circ} \mathrm{C}$ ("touchdown") and $30^{\prime \prime}$ extension at $72^{\circ} \mathrm{C}$, followed by 22 additional, similar cycles but with annealing at $56^{\circ} \mathrm{C}$, and $5^{\prime}$ final extension at $72^{\circ} \mathrm{C}$. Primer names and sequences, linkage group, allele sizes and cycling conditions for each molecular marker are detailed in Table 1. Amplified fragments were separated and analyzed through horizontal electrophoresis in $2 \%$ agarose gels in $1 \mathrm{X}$ TBE buffer, stained with GelRed ${ }^{\circledR}$ (Biotium) during $15 \mathrm{~min}$ at $100 \mathrm{~V}$ and exposed to UV light. Also, fragments were analyzed through electrophoresis in denaturing 6\% polyacrylamide-urea gels (Sambrook et al. 2001) stained with silver nitrate following the protocol described by Benbouza et al. (2006). In this case, fragment visualization was performed by exposing gels to white light. Allelic variants were assigned to each RIL according to their parent of origin, as ' $\mathrm{B}$ ' for 'Baguette 10 ' and ' $\mathrm{K}$ ' for 'Klein Chajá'. A few heterozygous individuals were detected and discarded from further analyses.

\section{Statistical analysis}

Statistical analysis was performed using the package nlme (Pinheiro et al. 2017) of the Rsoftware (R-Core Team 2017). A linear fixed effects model including year, genotype, block nested in year, and genotype-byyear interaction effects on phenotypic variables, was used. Variances from the model were used to calculate broad-sense heritability $\left(H^{2}\right)$ for each trait according to Hallauer et al. (2010) as:

$$
H^{2}=\frac{\hat{\sigma}_{g}^{2}}{\hat{\sigma}_{e}^{2} / r e+\hat{\sigma}_{g e}^{2} / e+\hat{\sigma}_{g}^{2}}
$$

with $\hat{\sigma}_{g}^{2}$ as genotypic variance, $\hat{\sigma}_{e}^{2}$ as environmental variance, $\hat{\sigma}_{g e}^{2}$ as the genotype-by-environment (year) variance, $r$ as the number of replications or blocks nested in environment and $\boldsymbol{e}$ as the number of environments (years).

In order to detect genomic regions associated with the evaluated traits, a linear fixed effects model was run for each marker, including marker, year, block nested in year, and the marker-by-year interaction effects. Bonferroni correction was applied in multiple comparisons using a family-wise error rate of 0.05. When a significant marker-by-year interaction effect was detected, the marker effect was analyzed for each year individually. When a significant marker-trait association was detected, the percentage of phenotypic variation explained by the marker was calculated as the quotient between the sum of squares of the marker and the total sum of squares $\mathrm{x} 100$. The marker effect was calculated as the difference between the mean in the group ' $\mathrm{B}$ ' and the mean in the group ' $\mathrm{K}$ '.

Haplotypes were constructed with one marker per region associated with SF. In chromosome 7AS, the chosen marker was the one with the lowest $\mathrm{p}$-value. Differences between these groups were tested with the Tukey test $(\alpha=0.05)$. 


\begin{tabular}{|c|c|c|c|c|}
\hline Linkage group & Marker & Type & Reference & Primer sequences \\
\hline $2 \mathrm{AL}$ & Xgwm 372 & SSR & Röder et al. (1998) & $\begin{array}{l}\text { F AATAGAGCCCTGGGACTGGG } \\
\text { R GAAGGACGACATTCCACCTG }\end{array}$ \\
\hline $2 \mathrm{AS}$ & Xwmc63 & SSR & Somers and Isaac (2004) & $\begin{array}{l}\text { F GTGCTCTGGAAACCTTCTACGA } \\
\text { R CAGTAGTTTAGCCTTGGTGTGA }\end{array}$ \\
\hline $2 \mathrm{BL}$ & $X w m c 317$ & SSR & Somers and Isaac (2004) & $\begin{array}{l}\text { F TGCTAGCAATGCTCCGGGTAAC } \\
\text { R TCACGAAACCTTTTCCTCCTCC }\end{array}$ \\
\hline 3BS & Xgwm493 & SSR & Röder et al. (1998) & $\begin{array}{l}\text { F TTCCCATAACTAAAACCGCG } \\
\text { R GGAACATCATTTCTGGACTTTG }\end{array}$ \\
\hline $3 \mathrm{DS}$ & Xgwm314 & SSR & Röder et al. (1998) & $\begin{array}{l}\text { F AGGAGCTCCTCTGTGCCAC } \\
\text { R TTCGGGACTCTCTTCCCTG }\end{array}$ \\
\hline $4 \mathrm{BL}$ & Xgwm495 & SSR & Röder et al. (1998) & $\begin{array}{l}\text { F GAGAGCCTCGCGAAATATAGG } \\
\text { R TGCTTCTGGTGTTCCTTCG }\end{array}$ \\
\hline $4 \mathrm{DL}$ & Xgwm194 & SSR & Röder et al. (1998) & $\begin{array}{l}\text { F GATCTGCTCTACTCTCCTCC } \\
\text { R CGACGCAGAACTTAAACAAG }\end{array}$ \\
\hline 4DS & $R h t D 1$ & $\begin{array}{l}\text { Functional } \\
\text { marker }\end{array}$ & Ellis et al. (2002) & $\begin{array}{l}\text { DF CGCGCAATTATTGGCCAGAGATAG } \\
\text { DF2 GGCAAGCAAAAGCTTCGCG } \\
\text { MR2 CCCATGGCCATCTCGAGCTGCTA } \\
\text { WR2 GGCCATCTCGAGCTGCAC }\end{array}$ \\
\hline $5 \mathrm{AL}$ & $\operatorname{VrnA1}$ & $\begin{array}{l}\text { Functional } \\
\text { marker }\end{array}$ & Xue et al. (2008) & $\begin{array}{l}\text { F GCGCAACAAGATCAGACTCA } \\
\text { R ACGCTTATATGGGCTGGAAG }\end{array}$ \\
\hline $5 \mathrm{AL}$ & Xbarc151 & SSR & http://www.scabusa.org & $\begin{array}{l}\text { F TGAGGAAAATGTCTCTATAGCATCC } \\
\text { R TGAGGAAAATGTCTCTATAGCATCC }\end{array}$ \\
\hline $5 \mathrm{AL}$ & Xgwm291 & SSR & Röder et al. (1998) & $\begin{array}{l}\text { F CATCCCTACGCCACTCTGC } \\
\text { R AATGGTATCTATTCCGACCCG }\end{array}$ \\
\hline $5 \mathrm{AL}$ & Xgwm293 & SSR & Röder et al. (1998) & $\begin{array}{l}\text { F TACTGGTTCACATTGGTGCG } \\
\text { R TCGCCATCACTCGTTCAAG }\end{array}$ \\
\hline $5 \mathrm{AL}$ & Xgwm304 & SSR & Röder et al. (1998) & $\begin{array}{l}\text { F AGGAAACAGAAATATCGCGG } \\
\text { R AGGACTGTGGGGAATGAATG }\end{array}$ \\
\hline $5 \mathrm{BL}$ & Xgwm335 & SSR & Röder et al. (1998) & $\begin{array}{l}\text { F CGTACTCCACTCCACACGG } \\
\text { R CGGTCCAAGTGCTACCTTTC }\end{array}$ \\
\hline $5 \mathrm{BL}$ & Xgwm 213 & SSR & Röder et al. (1998) & $\begin{array}{l}\text { F TGCCTGGCTCGTTCTATCTC } \\
\text { R CTAGCTTAGCACTGTCGCCC }\end{array}$ \\
\hline $5 \mathrm{BS}$ & Xgwm540 & SSR & Röder et al. (1998) & $\begin{array}{l}\text { F TCTCGCTGTGAAATCCTATTTC } \\
\text { R AGGCATGGATAGAGGGGC }\end{array}$ \\
\hline $5 \mathrm{DS}$ & Xgwm190 & SSR & Röder et al. (1998) & $\begin{array}{l}\text { F GTGCTTGCTGAGCTATGAGTC } \\
\text { R GTGCCACGTGGTACCTTTG }\end{array}$ \\
\hline $6 \mathrm{AS}$ & Xgwm 427 & SSR & Röder et al. (1998) & $\begin{array}{l}\text { F AAACTTAGAACTGTAATTTCAGA } \\
\text { R AGTGTGTTCATTTGACAGTT }\end{array}$ \\
\hline $6 \mathrm{BL}$ & Xgwm626 & SSR & Röder et al. (1998) & $\begin{array}{l}\text { F GATCTAAAATGTTATTTTCTCTC } \\
\text { R TGACTATCAGCTAAACGTGT }\end{array}$ \\
\hline $7 \mathrm{AS}$ & $X g w m 282$ & SSR & Röder et al. (1998) & $\begin{array}{l}\text { F TTGGCCGTGTAAGGCAG } \\
\text { R TCTCATTCACACACAACACTAGC }\end{array}$ \\
\hline $7 \mathrm{AS}$ & Xgwm332 & SSR & Röder et al. (1998) & $\begin{array}{l}\text { F AGCCAGCAAGTCACCAAAAC } \\
\text { R AGTGCTGGAAAGAGTAGTGAAGC }\end{array}$ \\
\hline 7AS & Xpsp3050 & SSR & Bryan et al. (1997) & $\begin{array}{l}\text { F CCGATAAAAGTTTAGCGACCC } \\
\text { R TAACTCACCTGCGAACTGTG }\end{array}$ \\
\hline 7AS & Xpsp3094.1 & SSR & Bryan et al. (1997) & $\begin{array}{l}\text { F ACCAGGAGAGATAGTCGTTAGGC } \\
\text { R TTTGTACACCATGATAGGCTTCC }\end{array}$ \\
\hline $7 \mathrm{AS}$ & Xwmc790 & SSR & Somers and Isaac (2004) & $\begin{array}{l}\text { F CGACAACGTACGCGCC } \\
\text { R CGACAACGTACGCGCC }\end{array}$ \\
\hline $7 \mathrm{BL}$ & Xgwm 344 & SSR & Röder et al. (1998) & $\begin{array}{l}\text { F CAAGGAAATAGGCGGTAACT } \\
\text { R ATTTGAGTCTGAAGTTTGCA }\end{array}$ \\
\hline 7BS & Xgwm46 & SSR & Röder et al. (1998) & $\begin{array}{l}\text { F GCACGTGAATGGATTGGAC } \\
\text { R TGACCCAATAGTGGTGGTCA }\end{array}$ \\
\hline
\end{tabular}




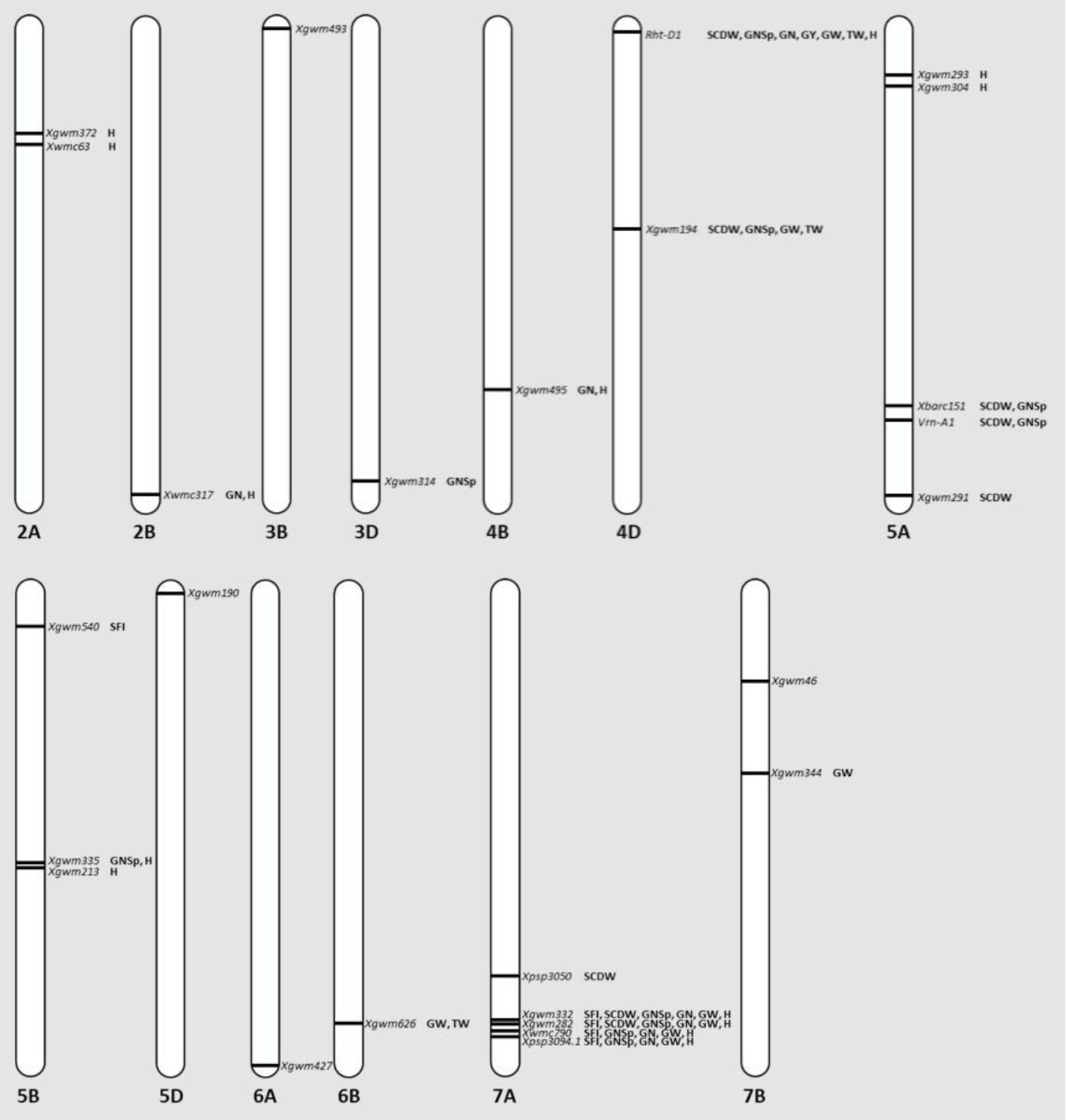

Figure S1. Approximate chromosome location of polymorphic markers used in this study and traits with which markers were associated. 


\section{RESULTS AND DISCUSSION}

\section{Environmental conditions}

The environmental conditions under which the experiments were performed are fully described in Alonso et al. (2018a). Conspicuous inter-annual environmental variation was observed, even though all experiments were carried out with no water or nutrient limitations and with chemical control of pests and fungal diseases.

\section{Phenotypic variation of RIL population}

Phenotypic data description is fully detailed in Alonso et al. $(2018 \mathrm{a}, \mathrm{b})$. Evaluated traits showed a bell-shaped and symmetrical distribution across all years (Fig. S2). Mean standard deviation and coefficient of variation for the analyzed traits in the RIL population are presented in Table 2. 'Baguette 10' had higher values of SF, grain yield and $\mathrm{GN} \mathrm{m}^{-2}$ than those of 'Klein Chajá'. Significant effects of genotype, year and genotype-by-year interaction were detected for all the traits in the RIL population (Table 3). However, the genetic variance was always greater than genotype-by-year interaction variance. All traits showed moderate to high broad-sense heritability (Table 3), which is essential for meaningful QTL detection. Although field evaluations comprising a larger number of environments are needed, these results suggest stability in SF, in line with previous findings (Abbate et al. 2013; Elía et al. 2016; Gonzalez-Navarro et al. 2016; Mirabella et al. 2016). This further supports the possibility of using molecular markers linked to the trait.

\section{Molecular marker analysis}

A total of 24 out of 200 SSR markers, plus two functional markers, were analyzed in the RIL population for their polymorphism between the parents and cosegregation with $\mathrm{SF}$ in the $\mathrm{F}_{3}$ generation. Even though a very low number of polymorphic markers was found, 55 significant single marker-trait associations were detected (Tables 4, 6; Fig. S1). A significant year effect was found in all cases, whereas significant markerby-year interaction effects $(\mathrm{p}<0.05)$ were detected in only eleven out of 55 cases (Tables 4,6 ). No crossover interactions were found. Genome coverage reached by these polymorphic markers was low and markers were not evenly distributed. Also, many linkage groups were not covered. This may lead to biased results, with phenotypic variation only being explained by covered regions. Nevertheless, significant regions explaining an interesting amount of variation $\left(\mathrm{R}^{2}=0.6\right.$ to $24 \%$; Tables 4, 6 and 7) were detected for the reported traits.

\section{Markers associated with spike fertility index}

Five markers were associated with SF (Table 4), one on chromosome 5BS (Xgwm540) and four on chromosome 7AS. The highest proportion of explained variance for a marker in $\mathrm{SF}$ was that of Xwmc79o $\left(\mathrm{R}^{2}=3.7 \%\right)$ with a positive effect of allele ' $\mathrm{B}$ '. On chromosome $5 \mathrm{BS}$, genotypes carrying the ' $\mathrm{K}$ ' allele in marker Xgwm540 showed the highest SF values (Table 4). Presence of high SF alleles in the low SF parent is expected, as transgressive segregation was observed in this population (Fig. S2) (Martino et al. 2015; Alonso et al. 2018b). Such alleles are interesting because further variability for the trait can be exploited even in "bad" genotypes, for stacking favorable minor alleles. Thus, the selection of extreme superior phenotypes could further increase SF and, in extension, raise grain yield (Slafer et al. 2015; Fischer and Rebetzke 2018).

Haplotypes constructed with these two markers yielded four genotypic groups. In all cases (Table 5), haplotype Xwmc79o-B/ Xgwm540-K showed the highest $\mathrm{SF}$, whereas the haplotype Xwmc79o-K/Xgwm540-B showed the lowest SF $(\mathrm{p}<0.05)$. Haplotypes with the remaining allele combinations had intermediate SF values. Also, haplotype ranking was the same across years. On average, SF difference between extreme haplotypes was $\sim 7 \%$; according to results reported by Alonso et al. (2018b), this could represent a difference in $\mathrm{GN} \mathrm{m}^{-2}$ potentially associated with a significant grain yield increase.

\section{Markers associated with other traits}

Spike chaff dry weight. Eight marker-trait associations were detected in four chromosomic regions, with effects ranging between 3.6 and 4.4\% (Table 6 ). Two of these markers, on chromosome 7AS, co-localized with SF as well. All markers on 7AS showed a positive effect of allele 'B', except for Xpsp3050. When analyzed by year, a significant negative effect of $V r n-A 1-B$ on $5 A L$ was observed at all three years, but the magnitude of such effect varied across years (Table 7).

Grain number per spike. Ten marker associations with $\mathrm{GN} /$ spike were detected in four chromosomic regions (Table 6). These results are partly coincident with the ones reported by Quarrie et al. $(2005,2006)$ and Hai et al. (2008). These authors detected QTL associated with grain number per spike in chromosome 7AS of a doubled haploid population. Marker effect ranged between 3.4 and $7.6 \%$ (Table 6). RhtD1 had a significant association with GN/spike at all three years, with a negative effect of allele ' $B$ '. However, the marker effect in 2014 was almost three times greater than that of 2013 and 2015 (Table 7). Marker Xgwm335 (5BL) showed significant marker by year interaction due to its association with GN/spike only in 2014 and 2015, with a similar magnitude (Table 7). No additional association was detected for Xgwm540, even though it had been described as a yield-related marker in a set of Serbian cultivars (Kobiljski et al. 2007). 
Grain number per square meter. Seven markers on four regions showed a significant effect on $\mathrm{GN} \mathrm{m}^{-2}$ (Table 6), notably those on chromosome 7AS which in turn were associated with SF. This is expected, given that these two traits are positively correlated (Acreche $e$ al. 2008, Terrile et al. 2017; Lo Valvo et al. 2018; Alonso et al. 2018b). Three markers had a significant marker-by-year interaction effect. The Rht-D1 gene (4DS) showed the strongest effect. In 2013 and 2014 the variation explained by the marker was notably higher than in 2015 (Table 7).

Grain yield. Grain yield was only associated with allelic variation at Rht-D1 (4DS). A significant marker-by-year interaction was detected, similar to the one observed for GN $\mathrm{m}^{-2}$. Similarly, grain yield variation due to this gene was far greater in 2013 and 2014 than it was in 2015 (Table 7).

Grain weight. Eight marker-trait associations were detected for grain weight on five regions, with no markerby-year interaction. Markers with effect on SF on 7AS also showed effect for this trait, with the opposite effect. However, this is unsurprising, as a negative genetic correlation has been reported between $\mathrm{SF}$ and grain weight (Ferrante et al. 2012, 2015; Gonzalez-Navarro et al. 2016; Terrile et al. 2017; Alonso et al. 2018b). The variability explained by each marker ranged between 2.6 and $5.2 \%$ (Table 6). In this population, Alonso et al. (2018a, b) reported a negative correlation of SF with grain weight, which can lead to a tradeoff between $\mathrm{SF}$ and grain weight (Ferrante et al. 2015; Slafer et al. 2015; Gonzalez-Navarro et al. 2016; Terrile et al. 2017), but also to unbalances in the sink/source ratio (Alonso et al. 2018a). Besides, markers associated with grain weight were detected in several genomic regions, not linked to those associated with SF (Table 6).

Test weight. Three independent markers were associated with test weight, without marker-by-year interaction effect. The highest association was found with Rht-D1
(4DS), which explained $~ 3 \%$ of the total variation (Table 6 ).

Plant height. Thirteen markers showed a significant effect on plant height; eleven of them, located on seven regions, showed no marker-by-year interaction. The remaining two markers, on chromosomes 4DS and $5 \mathrm{AL}$, did show such interaction (Table 6). Marker effect ranged mainly between 3.2 and $6.7 \%$, except for Rht-D1. It showed a significant marker-by-year interaction effect. Variation at this gene was associated with plant height at all three years with a positive effect of allele ' $\mathrm{B}$ ', but it explained a different portion of total variation depending on the year ( $18-24 \%$; Table 7$)$. Marker Xgwm293 on chromosome 5AL showed a similar pattern, respectively, explaining 3.8 and $5.4 \%$ of plant height variation in 2014 and 2015, with a negative effect of allele 'B'. Regarding chromosome 5BL, marker Xgwm213 was reported as associated with this trait by Wang et al. (2010) in a RIL population, and by Zhang et al. (2011) in a doubled haploid population. Although not associated with SF, these results give support for the marker analysis approach used in the present study.

In this study, a low genome coverage was reached, partly due to the lack of polymorphic microsatellites between the parents of the RIL population. This is also reflected in the phenotypic variability that was not explained by the available genotypic information. However, a few genomic regions associated with $\mathrm{SF}$ and related traits were detected, which were stable trough different years with different environmental conditions. Using the two markers that were most associated with SF in this study (located in chromosomes 5BS and 7AS, respectively), it was possible to classify lines into high, intermediate and low SF groups. Further studies with higher genome coverage and additional phenotypic evaluations are needed to validate the present results and to delimit genomic regions containing genes that control SF.

\begin{tabular}{|c|c|c|c|c|c|c|c|c|c|}
\hline & \multicolumn{3}{|c|}{ Mean } & \multicolumn{3}{|c|}{ Standard deviation } & \multicolumn{3}{|c|}{ Coefficient of variation } \\
\hline & 2013 & 2014 & 2015 & 2013 & 2014 & 2015 & 2013 & 2014 & 2015 \\
\hline Spike fertility index (grains g-1) & 98.3 & 91.9 & 89.4 & 9.2 & 11.7 & 9.5 & 9.4 & 12.8 & 10.6 \\
\hline Spike chaff dry weight (g spike ${ }^{-1}$ ) & 0.47 & 0.46 & 0.57 & 0.07 & 0.08 & 0.09 & 15.8 & 16.9 & 14.8 \\
\hline Grain number per spike (grains spike ${ }^{-1}$ ) & 45.5 & 42.3 & 50.6 & 5.8 & 6.9 & 6.7 & 12.8 & 16.4 & 13.1 \\
\hline Grain number per $\mathrm{m}^{2}\left(\mathrm{GN} \mathrm{m}^{-2}\right)$ & 21916 & 9964 & 17824 & 6382 & 2687 & 3457 & 29.1 & 26.9 & 19.4 \\
\hline Grain yield $\left(\mathrm{g} \mathrm{m}^{-2}\right)$ & 717.7 & 367.1 & 749.1 & 185.9 & 89.4 & 123.5 & 25.9 & 24.4 & 16.5 \\
\hline Grain weight (g 1000 grains $^{-1}$ ) & 33.0 & 37.4 & 42.5 & 4.2 & 4.6 & 3.8 & 12.6 & 12.2 & 8.9 \\
\hline Test weight $\left(\mathrm{kg} \mathrm{hl}^{-1}\right)$ & 79.4 & 73.8 & 80.3 & 2.3 & 2.2 & 1.8 & 2.8 & 3.0 & 2.3 \\
\hline Plant height $(\mathrm{cm})$ & 101.6 & 97.5 & 97.2 & 11.5 & 12.3 & 15.4 & 11.3 & 12.7 & 15.8 \\
\hline
\end{tabular}


Table 3. Analysis of variance of spike fertility index, spike chaff dry weight, grain number per spike, grain number per m2, grain yield, grain weight, test weight and plant height of a RIL population ('Baguette 10' x 'Klein Chajá') evaluated in 2013, 2014 and 2015 at Balcarce, Argentina. Broad-sense heritability $\left(H^{2}\right)$ values. Partially published data (Alonso et al. 2018a,b).

\begin{tabular}{|c|c|c|c|c|c|}
\hline Trait & Factor & Degrees of freedom & Mean Square & $P(>F)$ & $\mathbf{H}^{2}$ \\
\hline \multirow[t]{5}{*}{ Spike fertility index } & Genotype (G) & 145 & 344.7 & $<0.0001$ & 0.86 \\
\hline & Year (Y) & 2 & 6219.7 & $<0.0001$ & \\
\hline & Block in $\mathrm{Y}$ & 3 & 203.7 & 0.0047 & \\
\hline & Gx $\mathrm{Y}$ & 288 & 63.3 & 0.0021 & \\
\hline & Residuals & 416 & 46.5 & & \\
\hline \multirow[t]{5}{*}{$\begin{array}{l}\text { Spike chaff dry } \\
\text { weight }\end{array}$} & Genotype (G) & 145 & 0.0169 & $<0.0001$ & 0.70 \\
\hline & Year (Y) & 2 & 1.05354 & $<0.0001$ & \\
\hline & Block in $\mathrm{Y}$ & 3 & 0.06167 & $<0.0001$ & \\
\hline & Gx Y & 288 & 0.00481 & $<0.0001$ & \\
\hline & Residuals & 416 & 0.00316 & & \\
\hline \multirow[t]{5}{*}{$\begin{array}{l}\text { Grain number per } \\
\text { spike }\end{array}$} & Genotype (G) & 145 & 135 & $<0.0001$ & 0.78 \\
\hline & Year (Y) & 2 & 4999 & $<0.0001$ & \\
\hline & Block in $\mathrm{Y}$ & 3 & 262.6 & $<0.0001$ & \\
\hline & $\mathrm{G} \times \mathrm{Y}$ & 288 & 27.4 & 0.0001 & \\
\hline & Residuals & 417 & 18.5 & & \\
\hline \multirow[t]{5}{*}{ Grain number per $\mathrm{m}^{2}$} & Genotype (G) & 145 & 44584000 & $<0.0001$ & 0.52 \\
\hline & Year (Y) & 2 & $1.0376 \mathrm{E}+10$ & $<0.0001$ & \\
\hline & Block in $\mathrm{Y}$ & 3 & 297900000 & $<0.0001$ & \\
\hline & $\mathrm{G} \times \mathrm{Y}$ & 288 & 20764000 & $<0.0001$ & \\
\hline & Residuals & 411 & $8.77 \mathrm{E}+06$ & & \\
\hline \multirow[t]{5}{*}{ Grain yield } & Genotype (G) & 145 & 34708 & $<0.0001$ & 0.42 \\
\hline & Year (Y) & 2 & 12908156 & $<0.0001$ & \\
\hline & Block in $\mathrm{Y}$ & 3 & 455230 & $<0.0001$ & \\
\hline & $\mathrm{G} \times \mathrm{Y}$ & 288 & 21296 & $<0.0001$ & \\
\hline & Residuals & 422 & 9498 & & \\
\hline \multirow[t]{5}{*}{ Grain weight } & Genotype (G) & 145 & 56.2 & $<0.0001$ & 0.67 \\
\hline & Year (Y) & 2 & 6419.2 & $<0.0001$ & \\
\hline & Block in $\mathrm{Y}$ & 3 & 1.3 & 0.9153 & \\
\hline & Gx Y & 288 & 13.2 & $<0.0001$ & \\
\hline & Residuals & 420 & 7.7 & & \\
\hline \multirow[t]{5}{*}{ Test weight } & Genotype (G) & 145 & 18.3 & $<0.0001$ & 0.63 \\
\hline & Year (Y) & 2 & 3652.7 & $<0.0001$ & \\
\hline & Block in $Y$ & 3 & 4.1 & 0.0063 & \\
\hline & $\mathrm{G} \times \mathrm{Y}$ & 288 & 2.6 & $<0.0001$ & \\
\hline & Residuals & 421 & 1 & & \\
\hline \multirow[t]{5}{*}{ Plant height } & Genotype (G) & 145 & 831.32 & $<0.0001$ & 0.93 \\
\hline & Year (Y) & 2 & 1810.98 & $<0.0001$ & \\
\hline & Block in $Y$ & 3 & 45.47 & 0.1732 & \\
\hline & $\mathrm{G} \times \mathrm{Y}$ & 288 & 61.17 & $<0.0001$ & \\
\hline & Residuals & 429 & 27.26 & & \\
\hline
\end{tabular}




\section{Allelic difference ${ }^{a}$}

\begin{tabular}{lccccc} 
Marker & Chromosome & p-value & $\mathbf{R}^{2}$ & grains/g chaff & $\%$ \\
\hline Xgwm540 & 5BS & $<0.001$ & 1.4 & -2.44 & -2.6 \\
Xgwm282 & $7 \mathrm{AS}$ & $<0.001$ & 2.8 & 3.49 & 3.7 \\
Xgwm332 & 7AS & $<0.001$ & 1.4 & 2.46 & 2.6 \\
Xpsp3094.1 & $7 \mathrm{AS}$ & $<0.001$ & 2.3 & 3.21 & 3.4 \\
Xwmc790 & 7AS & $<0.001$ & 3.7 & 4.09 & 4.4 \\
\hline
\end{tabular}

a Average spike fertility index difference between lines with the ' $\mathrm{B}$ ' vs. the ' $\mathrm{K}$ ' allele.

Table 5. Spike fertility index (grains / g chaff) of haplotypes at the two markers most significantly associated with the trait in a RIL population ('Baguette 10' X 'Klein Chajá') evaluated in 2013, 2014 and 2015 at Balcarce, Argentina. The'B' and ' $\mathrm{K}$ ' denote lines with the 'B' and the ' $K$ ' allele, respectively. Same letters within a column indicate non-significant differences $(p>0.05)$.

\begin{tabular}{|c|c|c|c|c|c|c|c|c|c|c|}
\hline \multicolumn{2}{|l|}{ Haplotype } & \multirow[b]{2}{*}{$\mathbf{N}$} & \multicolumn{8}{|c|}{ Spike fertility index } \\
\hline Xwmc790 & Xgwm540 & & Mean & & 2013 & & 2014 & & 2015 & \\
\hline B & $\mathrm{K}$ & 30 & 95.8 & $\mathrm{a}$ & 101.3 & $\mathrm{a}$ & 95.2 & $\mathrm{a}$ & 91.1 & $\mathrm{a}$ \\
\hline B & $\mathrm{B}$ & 34 & 93.4 & $a b$ & 99.0 & $a b$ & 91.8 & $a b$ & 89.4 & $a b$ \\
\hline K & $\mathrm{K}$ & 31 & 92.4 & $\mathrm{bc}$ & 96.8 & $\mathrm{~b}$ & 91.6 & $a b$ & 88.7 & $a b$ \\
\hline K & $\mathrm{B}$ & 22 & 89.7 & $\mathrm{c}$ & 95.5 & $\mathrm{~b}$ & 87.0 & $\mathrm{~b}$ & 86.5 & $\mathrm{~b}$ \\
\hline
\end{tabular}


Table 6. Molecular markers associated with spike chaff dry weight, grain number per spike, grain number per $\mathrm{m}^{2}$, grain yield, grain weight, test weight and plant height of a RIL population ('Baguette 10' x 'Klein Chajá') evaluated in 2013, 2014 and 2015 at Balcarce, Argentina.

\begin{tabular}{|c|c|c|c|c|c|c|c|}
\hline \multirow[b]{2}{*}{ Trait } & \multirow[b]{2}{*}{ Marker } & \multirow[b]{2}{*}{ Chromosome } & \multirow[b]{2}{*}{ p-value } & \multirow[b]{2}{*}{$\mathbf{R}^{2 \%}$} & \multicolumn{3}{|c|}{ Allelic difference ${ }^{a}$} \\
\hline & & & & & Trait units & $\%$ & \\
\hline \multirow{8}{*}{$\begin{array}{l}\text { Spike chaff dry weight } \\
\left(\mathrm{g} \mathrm{spike}^{-1}\right)\end{array}$} & $R h t-D 1$ & 4DS & $<0.001$ & 1.7 & -0.026 & -5.1 & * \\
\hline & Xgwm194 & $4 \mathrm{DL}$ & $<0.001$ & 1.4 & -0.022 & -4.4 & \\
\hline & $V r n-A 1$ & $5 \mathrm{AL}$ & $<0.001$ & 4 & -0.039 & -7.8 & * \\
\hline & Xbarc151 & $5 \mathrm{AL}$ & $<0.001$ & 1.3 & -0.022 & -4.3 & \\
\hline & Xgwm291 & $5 \mathrm{AL}$ & 0.0014 & 0.9 & 0.018 & 3.6 & \\
\hline & Xgwm282 & 7AS & $<0.001$ & 1 & 0.018 & 3.7 & \\
\hline & Xgwm332 & 7AS & $<0.001$ & 1.1 & 0.020 & 4.0 & \\
\hline & Xpsp3050 & 7AS & $<0.001$ & 1 & -0.019 & -3.8 & \\
\hline \multirow{10}{*}{$\begin{array}{l}\text { Grain number per spike } \\
\left(\text { grains spike }^{-1}\right)\end{array}$} & Xgwm 314 & $3 \mathrm{DS}$ & 0.0018 & 1.1 & 1.56 & 3.4 & \\
\hline & $R h t-D 1$ & $4 \mathrm{DS}$ & $<0.001$ & 5.4 & -3.49 & -7.6 & $*$ \\
\hline & Xgwm194 & $4 \mathrm{DL}$ & $<0.001$ & 1.9 & -2.07 & -4.5 & \\
\hline & $V r n-A 1$ & $5 \mathrm{AL}$ & $<0.001$ & 4.4 & -3.20 & -6.9 & \\
\hline & Xbarc151 & $5 \mathrm{AL}$ & $<0.001$ & 2.7 & -2.42 & -5.2 & \\
\hline & Xgwm335 & $5 \mathrm{BL}$ & $<0.001$ & 1.9 & -2.06 & -4.5 & $*$ \\
\hline & Xgwm282 & 7AS & $<0.001$ & 5.6 & 3.40 & 7.4 & \\
\hline & Xgwm332 & 7AS & $<0.001$ & 4.4 & 3.08 & 6.7 & \\
\hline & Xpsp3094.1 & 7AS & $<0.001$ & 4.4 & 3.13 & 6.8 & \\
\hline & Xwmc790 & 7AS & $<0.001$ & 5.6 & 3.42 & 7.4 & \\
\hline \multirow[t]{7}{*}{ Grain number $\mathrm{m}^{-2}$} & Xwmc317 & $2 \mathrm{BL}$ & 0.0012 & 0.6 & -979.8 & -5.9 & \\
\hline & Xgwm495 & $4 \mathrm{BL}$ & 0.0019 & 0.6 & -1054.4 & -6.4 & $*$ \\
\hline & $R h t-D 1$ & 4DS & $<0.001$ & 3.7 & -2610.6 & -15.8 & $*$ \\
\hline & $\operatorname{Xgwm} 282$ & 7AS & $<0.001$ & 0.8 & 1103.4 & 6.7 & \\
\hline & Xgwm332 & 7AS & 0.0016 & 0.6 & 930.5 & 5.6 & \\
\hline & Xpsp3094.1 & 7AS & $<0.001$ & 1.1 & 1355.4 & 8.2 & \\
\hline & Xwmc790 & 7AS & $<0.001$ & 1.2 & 1409.5 & 8.5 & $*$ \\
\hline Grain yield $\left(\mathrm{g} \mathrm{m}^{-2}\right)$ & $R h t-D 1$ & 4DS & $<0.001$ & 1.8 & -59.93 & -9.8 & $*$ \\
\hline \multirow{8}{*}{$\begin{array}{l}\text { Grain weight } \\
\left(\text { g } 1000 \text { grains }^{-1}\right)\end{array}$} & $R h t-D 1$ & 4DS & $<0.001$ & 2.3 & 1.66 & 4.4 & \\
\hline & Xgwm194 & $4 \mathrm{DL}$ & 0.0012 & 0.7 & 0.96 & 2.6 & \\
\hline & Xgwm626 & $6 \mathrm{BL}$ & $<0.001$ & 2.1 & -1.62 & -4.3 & \\
\hline & Xgwm282 & 7AS & $<0.001$ & 2.6 & -1.84 & -4.9 & \\
\hline & Xgwm332 & 7AS & $<0.001$ & 1.1 & -1.15 & -3.1 & \\
\hline & Xpsp3094.1 & 7AS & $<0.001$ & 3.1 & -1.96 & -5.2 & \\
\hline & Xwmc790 & 7AS & $<0.001$ & 2.4 & -1.76 & -4.7 & \\
\hline & Xgwm344 & $7 \mathrm{BL}$ & $<0.001$ & 1.0 & 1.18 & 3.1 & \\
\hline \multirow{3}{*}{$\begin{array}{l}\text { Test weight } \\
\left(\mathrm{kg} \mathrm{hl}^{-1}\right)\end{array}$} & $R h t-D 1$ & 4DS & $<0.001$ & 3.0 & 1.27 & 1.6 & \\
\hline & Xgwm194 & $4 \mathrm{DL}$ & $<0.001$ & 0.6 & 0.54 & 0.7 & \\
\hline & Xgwm626 & $6 \mathrm{BL}$ & $<0.001$ & 1.8 & -0.98 & -1.3 & \\
\hline \multirow{10}{*}{$\begin{array}{l}\text { Plant height } \\
(\mathrm{cm})\end{array}$} & Xgwm372 & $2 \mathrm{AL}$ & $<0.001$ & 2.4 & -4.1 & -4.2 & \\
\hline & Xwmc63 & $2 \mathrm{AS}$ & $<0.001$ & 1.3 & 3.0 & 3.1 & \\
\hline & Xwmc317 & $2 \mathrm{BL}$ & $<0.001$ & 1.5 & 3.2 & 3.2 & \\
\hline & Xgwm495 & $4 \mathrm{BL}$ & $<0.001$ & 2.2 & 3.9 & 4.0 & \\
\hline & $R h t-D 1$ & $4 \mathrm{DS}$ & $<0.001$ & 20 & 12.1 & 12.2 & $*$ \\
\hline & Xgwm 293 & $5 \mathrm{AL}$ & $<0.001$ & 2.7 & -4.4 & -4.4 & $*$ \\
\hline & Xgwm 304 & $5 \mathrm{AL}$ & $<0.001$ & 1.8 & -3.6 & -3.6 & \\
\hline & $X g w m 213$ & $5 \mathrm{BL}$ & $<0.001$ & 6.1 & 6.6 & 6.7 & \\
\hline & Xgwm335 & $5 \mathrm{BL}$ & $<0.001$ & 1.7 & 3.5 & 3.5 & \\
\hline & Xgwm282 & 7AS & $<0.001$ & 1.8 & -3.6 & -3.7 & \\
\hline
\end{tabular}


Table 7. Molecular markers which showed significant GxE interaction, associated with spike chaff dry weight, grain number per spike, grain number per $\mathrm{m}^{2}$, grain yield and plant height of a RIL population ('Baguette 10' x 'Klein Chajá') evaluated in 2013, 2014 and 2015 at Balcarce, Argentina.

\begin{tabular}{|c|c|c|c|c|c|c|c|}
\hline \multirow[b]{2}{*}{ Trait } & \multirow[b]{2}{*}{ Marker } & \multirow[b]{2}{*}{ Year } & \multirow[b]{2}{*}{ p-value } & & \multirow[b]{2}{*}{$\mathbf{R}^{2 \%}$} & \multicolumn{2}{|c|}{ Allelic difference ${ }^{a}$} \\
\hline & & & & & & Trait units & $\%$ \\
\hline Spike chaff dry weight & $R h t-D 1$ & 2013 & 0.108 & & & & \\
\hline \multirow[t]{4}{*}{$\left(\right.$ g spike $\left.^{-1}\right)$} & & 2014 & $<0.001$ & $*$ & 7.3 & -0.042 & -9.1 \\
\hline & & 2015 & 0.111 & & & & \\
\hline & $V r n-A 1$ & 2013 & 0.042 & $*$ & 1.8 & -0.020 & -4.3 \\
\hline & & 2014 & 0.002 & $\begin{array}{l}* \\
*\end{array}$ & $\begin{array}{r}3.8 \\
13\end{array}$ & -0.032 & -6.8 \\
\hline \multirow{5}{*}{$\begin{array}{l}\text { Grain number per spike } \\
\left(\text { grains spike }^{-1}\right)\end{array}$} & Rht-D1 & 2013 & $<0.001$ & $*$ & 4.6 & -2.4 & -5.3 \\
\hline & & 2014 & $<0.001$ & $*$ & 13 & -5.1 & -12.0 \\
\hline & & 2015 & $<0.001$ & $*$ & 4.2 & -2.7 & -5.4 \\
\hline & Xgwm335 & 2013 & 0.824 & & & & \\
\hline & & 2014 & 0.001 & $\begin{array}{l}* \\
*\end{array}$ & 4.3 & -2.9 & -6.9 \\
\hline \multirow[t]{9}{*}{ Grain number $\mathrm{m}^{-2}$} & $R h t-D 1$ & 2013 & $<0.001$ & $*$ & 13 & -4507.1 & -20.6 \\
\hline & & 2014 & $<0.001$ & $*$ & 19 & -2281.8 & -22.9 \\
\hline & & 2015 & 0.023 & $*$ & 1.7 & -916.5 & -5.1 \\
\hline & Xgwm495 & 2013 & 0.002 & $*$ & 4.2 & -2541.9 & -11.6 \\
\hline & & 2014 & 0.260 & & & & \\
\hline & & 2015 & 0.851 & & & & \\
\hline & Xwmc790 & 2013 & 0.001 & $*$ & 3.9 & 2547.8 & 11.6 \\
\hline & & 2014 & $<0.001$ & $*$ & 6.5 & 1362.9 & 13.7 \\
\hline & & 2015 & 0.165 & & & & \\
\hline \multirow{3}{*}{$\begin{array}{l}\text { Grain yield } \\
\left(\mathrm{g} \mathrm{m}^{-2}\right)\end{array}$} & $R h t-D 1$ & 2013 & $<0.001$ & $*$ & 8.1 & -107.5 & -15.0 \\
\hline & & 2014 & $<0.001$ & $*$ & 1.2 & -62.8 & -0.3 \\
\hline & & 2015 & 0.435 & & & & \\
\hline \multirow{6}{*}{$\begin{array}{l}\text { Plant Height } \\
(\mathrm{cm})\end{array}$} & $R h t-D 1$ & 2013 & $<0.001$ & $*$ & 18 & 9.8 & 9.7 \\
\hline & & 2014 & $<0.001$ & $*$ & 22 & 11.5 & 34.8 \\
\hline & & 2015 & $<0.001$ & $*$ & 24 & 14.8 & 2.1 \\
\hline & Xgwm293 & 2013 & 0.408 & & & & \\
\hline & & 2014 & 0.001 & $*$ & 3.8 & -4.8 & -10.6 \\
\hline & & 2015 & $<0.001$ & $*$ & 5.4 & -7.1 & -8.9 \\
\hline
\end{tabular}



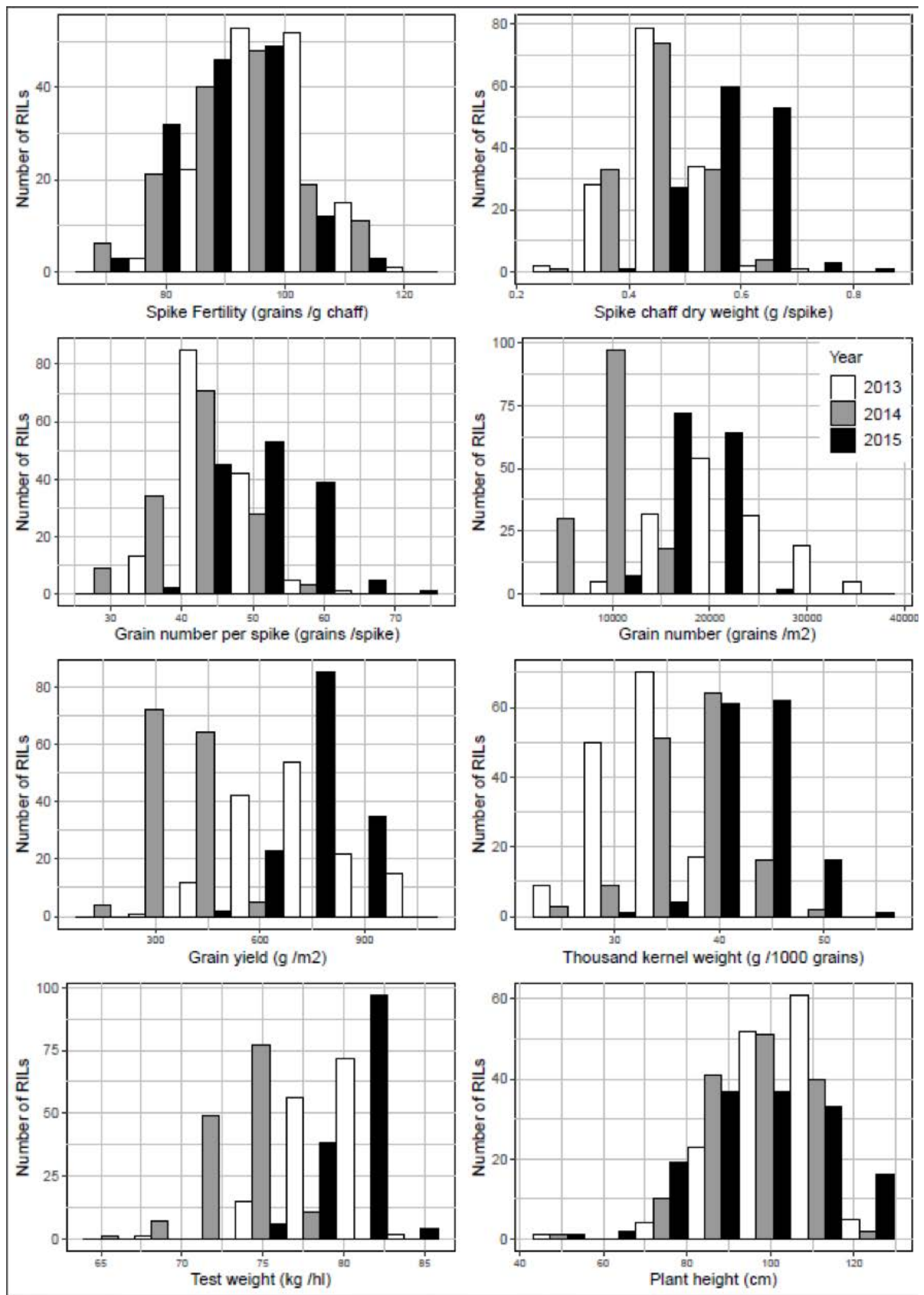

Figure S2. Histograms of (A) spike fertility index, (B) spike chaff dry weight, (C) grain number per spike, (D) grain number per $\mathrm{m}^{2}$, (E) grain yield, (F) grain weight, (G) test weight and (H) plant height, in a RIL population ('Baguette 10' x 'Klein Chajá') evaluated in 2013 (white), 2014 (grey) and 2015 (black) at Balcarce, Argentina. Values for the parents are indicated with stars ('Baguette 10') and triangles ('Klein Chajá'). 


\section{ACKNOWLEDGEMENTS}

We would like to thank members of the Grupo Trigo (Unidad Integrada EEA Balcarce INTA - FCA, UNMdP) for their help with the experiments and technical assistance. Scholarships granted to M.P. Alonso by the CONICET, to N.E. Mirabella by the INTA and to J.S. Panelo by the CIC, and partial funding by INTA (PNBIO 1131042), are acknowledged.

\section{REFERENCES}

Abbate PE, Pontaroli AC, Lázaro L and Gutheim F (2013) A method of screening for spike fertility in wheat. The Journal of Agricultural Science 151(3): 322-330. doi:10.1017/ So021859612000068

Acreche MM, Briceño-Félix G, Sánchez JAM and Slafer GA (2008) Physiological bases of genetic gains in Mediterranean bread wheat yield in Spain. European Journal of Agronomy 28(3): 162-170. doi:10.1016/j. eja.2007.07.001

Aisawi KAB, Reynolds MP, Singh RP and Foulkes MJ (2015) The physiological basis of the genetic progress in yield potential of CIMMYT spring wheat cultivars from 1966 to 2009. Crop Science 55(4): 1749-1764. doi:10.2135/cropsci2014.09.0601

Albajes R, Cantero-Martínez C, Capell T, Christou P, Farre A, Galceran J, LópezGatius F, Marin S, Martín-Belloso O, Motilva M, Nogareda C, Peman J, Puy J, Recasens J, Romagosa I, Romero M, Sanchis V, Savin R, Slafer GA, Soliva-Fortuny R, Viñas I, and Voltas J (2013) Building bridges: an integrated strategy for sustainable food production throughout the value chain. Molecular Breeding 32(4): 743-770. doi:10.1007/s11032-013-9915-z

Alonso MP, Abbate PE, Mirabella NE, Merlos FA, Panelo JS and Pontaroli AC (2018) a Analysis of sink/source relations in bread wheat recombinant inbred lines and commercial cultivars under a high yield potential environment. European Journal of Agronomy 93: 82-87. doi:10.1016/j. eja.2017.11.007

Alonso MP, Mirabella NE, Panelo JS, Cendoya MG and Pontaroli AC (2018)b Selection for high spike fertility index increases genetic progress in grain yield and stability in bread wheat. Euphytica 214(7): 112. doi:10.1007/ s10681-018-2193-4

Benbouza H, Jacquemin JM, Baudoin JP and Mergeai G (2006) Optimization of a reliable, fast, cheap and sensitive silver staining method to detect SSR markers in polyacrylamide gels. Biotechnologie, agronomie, société et environnement 10(2): 77-81.

Bryan GJ, Collins AJ, Stephenson P, Orry A, Smith JB and Gale MD (1997) Isolation and characterisation of microsatellites from hexaploid bread wheat. Theoretical and Applied Genetics 94(5): 557-563. doi:10.1007/s001220050451

Collard BC and Mackill DJ (2008) Markerassisted selection: an approach for precision plant breeding in the twentyfirst century. Philosophical Transactions of the Royal Society of London B: Biological Sciences 363(1491): 557-572. doi:10.1098/ rstb.2007.2170

Deperi SI (2012) Detección de marcadores moleculares asociados a la fertilidad de la espiga de trigo. Trabajo de Graduación. Ing. Agr. Universidad Nacional de Mar del Plata. Facultad de Ciencias Agrarias, Balcarce. 27 p. dat.num.il.

Elía M, Savin R and Slafer GA (2016) Fruiting efficiency in wheat: physiological aspects and genetic variation among modern cultivars. Field Crops Research 191: 83-90. doi:10.1016/j.fcr.2016.02.019

Ellis M, Spielmeyer W, Gale K, Rebetzke G and Richards R (2002) "Perfect" markers for the Rht-B1b and Rht-D1b dwarfing genes in wheat. Theoretical and Applied Genetics 105(6-7): 1038-1042. doi:10.1007/s00122$002-1048-4$

FAO (2018, December 10) FAOSTAT database. Agricultural crops: wheat area harvested/ yield. Http://faostat.fao.org/

Ferrante A, Savin R and Slafer GA (2012) Differences in yield physiology between modern, well adapted durum wheat cultivars grown under contrasting conditions. Field Crops Research 136: 52-64. doi:10.1016/j. fcr.2012.07.015

Ferrante A, Savin R and Slafer GA (2015) Relationship between fruiting efficiency and grain weight in durum wheat. Field Crops Research 177: 109-116. doi: 10.1016/j. fcr.2015.03.009

Fischer RA (1984) Wheat. In: Smith, WH, Banta, SJ (eds.) Potential productivity of field crops under different environments; International Rice Research Institute. Los Baños, Philippines, p 129-154.

Fischer RA (2011) Wheat physiology: a review of recent developments. Crop and Pasture Science 62(2): 95-114. doi:10.1071/CP10344

Fischer RA and Rebetzke GJ (2018) Indirect selection for potential yield in earlygeneration, spaced plantings of wheat and other small-grain cereals: a review. Crop and Pasture Science 69(5): 439-459. doi:10.1071/ CP17409

González FG, Aldabe ML, Terrile II and Rondanini DP (2014) Grain weight response to different post flowering source: sink ratios in modern high-yielding Argentinean Wheats differing in spike fruiting efficiency. Crop Science 54(1): 297-309. doi:10.2135/cropsci2013.03.0157
Gonzalez-Navarro OE, Griffiths S, Molero G, Reynolds MP and Slafer GA (2016) Variation in developmental patterns among elite wheat lines and relationships with yield, yield components and spike fertility. Field Crops Research 196: 294-304. doi:10.1016/j. fcr.2016.07.019

Guo Z, Slafer GA and Schnurbusch T (2016) Genotypic variation in spike fertility traits and ovary size as determinants of floret and grain survival rate in wheat. Journal of experimental botany 67(14): 4221-4230. doi:10.1093/jxb/erw200

Guo Z, Chen D, Alqudah AM, Röder MS, Ganal MW, and Schnurbusch, T (2017). Genome wide association analyses of 54 traits identified multiple loci for the determination of floret fertility in wheat. New Phytologist 214(1), 257-270. doi: 10.1111/nph.14342

Hai L, Guo H, Wagner C, Xiao S and Friedt W (2008) Genomic regions for yield and yield parameters in Chinese winter wheat (Triticum aestivum L.) genotypes tested under varying environments correspond to QTL in widely different wheat materials. Plant science 175(3): 226-232. doi:10.1016/j. plantsci.2008.03.006

Hallauer AR, Carena MJ and Miranda Filho JB (2010) Quantitative genetics in maize breeding. Springer, New York, 664p.

Haymes KM (1996) Mini-prep method suitable for a plant breeding program. Plant Molecular Biology Reporter 14(3): 280-284. doi:10.1007/BF02671664

Kobiljski B, Denčić S, Hristov N, Mladenov N, Quarrie S, Stephenson P and Kirby J (2007) Potential uses of microsatellites in markerassisted selection for improved grain yield in wheat. In Wheat Production in Stressed Environments. Springer, Dordrecht, p. 729736. doi:10.1007/1-4020-5497-1_89

Lo Valvo PJ, Miralles D J and Serrago RA (2018) Genetic progress in Argentine bread wheat varieties released between 1918 and 2011: Changes in physiological and numerical yield components. Field Crops Research 221: 314-321. doi:10.1016/j.fcr.2017.08.014

Martino DL, Abbate PE, Cendoya MG, Gutheim F, Mirabella NE and Pontaroli AC (2015) Wheat spike fertility: inheritance and relationship with spike yield components in early generations. Plant Breeding 134(3): 264-270. doi:10.1111/pbr.12262

Michelmore RW, Paran I and Kesseli RV (1991) Identification of markers linked to disease resistance genes by bulk segregant analysis: a rapid method to detect markers in specific genomic regions by using segregating populations. Proceedings of the National Academy of Sciences USA 88: 9828-9832.

Mirabella NE, Abbate PE, Ramirez IA and Pontaroli AC (2016) Genetic variation 
for wheat spike fertility in cultivars and early breeding materials. The Journal of Agricultural Science 154(1): 13-22. doi:10.1017/S0021859614001245

Pinheiro J, Bates D, Debroy S, Sarkar D and $\mathrm{R}$ Core Team (2017) Nlme: Linear and Nonlinear Mixed Effects Models. R package version 3.1-128. 2016. R software.

QuarrieSA, Steed A, Calestani C, Semikhodskii A, Lebreton C, Chinoy C, Steele N, Pljevljakusić D, Waterman E, Weyen J, Schondelmaier J, Habash DZ, Farmer P, Saker, L, Clarkson DT, Abugalieva A, Yessimbekova M, Turuspekov $\mathrm{Y}$, Abugalieva, R, Tuberosa R, Sanguineti MC, Hollington PA, Aragués R, Royo A and Dodig D (2005) A high-density genetic map of hexaploid wheat (Triticum aestivum L.) From the cross Chinese Spring $\times$ SQ1 and its use to compare QTLs for grain yield across a range of environments. Theoretical and Applied Genetics 110(5): 865-880. doi:10.1007/ s00122-004-1902-7

Quarrie SA, Pekic Quarrie S, Radosevic R, Rancic D, Kaminska A, Barnes JD, Leverington M, Ceolini C and Dodig D (2006) Dissecting a wheat QTL for yield present in a range of environments: from the QTL to candidate genes. Journal of Experimental Botany 57(11): 2627-2637. doi10.1093/jxb/erlo26

Ramirez IA, Abbate PE, Redi IW and Pontaroli AC (2018) Effects of photoperiod sensitivity genes $P p d-B 1$ and $P p d-D 1$ on spike fertility and related traits in bread wheat. Plant Breeding 137(3): 320-325. doi:10.1111/ pbr.12585

R-Core Team (2017) R: A language and environment for statistical computing.

Reynolds M, Foulkes J, Furbank R, Griffiths S, King J, Murchie E, Parry M and Slafer GA (2012) Achieving yield gains in wheat. Plant, Cell and Environment 35(10): 1799-1823. doi:10.1111/j.1365-3040.2012.02588.x

Röder MS, Korzun V, Wendehake K, Plaschke J, Tixier MH, Leroy P and Ganal MW (1998) A microsatellite map of wheat. Genetics 149(4): 2007-2023.

Sadras VO (2007) Evolutionary aspects of the trade-off between seed size and number in crops. Field Crops Research 100(2-3): 125138. doi: 10.1016/j.fcr.2006.07.004

Sambrook J, Maccallum P and Russell D (2001) Molecular Cloning: A Laboratory Manual (2nd ed.). Cold spring harbor laboratory press. $910 \mathrm{p}$.

SCABUSA (2018, December 10). US Wheat and Barley Scab Initiative. https://scabusa.org/

Slafer GA (2003) Genetic basis of yield as viewed from a crop physiologist's perspective. Annals of Applied Biology 142(2): 117-128. doi:10.1111/j.1744-7348.2003.tboo237.x
Slafer GA, Savin R and Sadras VO (2014) Coarse and fine regulation of wheat yield components in response to genotype and environment. Field Crops Research 157: 7183. doi:10.1016/j.fcr.2013.12.004

Slafer GA, Elia M, Savin R, García GA, Terrile II, Ferrante A, Miralles DJ and Gonzalez FG (2015) Fruiting efficiency: an alternative trait to further rise wheat yield. Food and Energy Security 4(2): 92-109. doi: 10.1002/ fes 3.59

Somers DJ, Isaac P and Edwards K (2004) A high-density microsatellite consensus map for bread wheat (Triticum aestivum L.). Theoretical and Applied Genetics 109(6): 1105-1114. doi:10.1007/s00122-004-1740-7

Terrile II, Miralles DJ and González FG (2017) Fruiting efficiency in wheat (Triticum aestivum L): Trait response to different growing conditions and its relation to spike dry weight at anthesis and grain weight at harvest. Field Crops Research 201: 86-96. doi: 10.1016/j.fcr.2016.09.026

Wang Z, Wu X, Ren $\mathrm{Q}$, Chang X, Li R and Jing R (2010) QTL mapping for developmental behavior of plant height in wheat (Triticum aestivum L.). Euphytica 174(3): 447-458. doi:10.1007/s10681-010-0166-3

Xue S, Zhang Z, Lin F, Kong Z, Cao Y, Li C, Yi H, Mei M, Zhu H, Wu J, Xu H, Zhao D, Tian D, Zhang C and Ma Z (2008) A highdensity intervarietal map of the wheat genome enriched with markers derived from expressed sequence tags. Theoretical and Applied Genetics 117(2): 181-189. doi:10.1007/s00122-008-0764-9

Zhang J, Hao C, Ren Q Chang X, Liu G and Jing R (2011) Association mapping of dynamic developmental plant height in common wheat. Planta 234(5): 891-902.doi:10.1007/s00425-011-143 


\section{KARYOLOGICAL STUDY IN THE CHILEAN RHATANY Krameria cistoidea HOOK. \& ARN. (KRAMERIACEAE)}

\section{ESTUDIO CARIOLÓGICO EN EL PACUL CHILENO Krameria cistoidea HOOK. \& ARN. (KRAMERIACEAE)}

Palma Rojas C. ${ }^{1 *}$, Jara Seguel P. ${ }^{2}$, García M. ${ }^{1}$, von Brand E. ${ }^{3}$, Araya Jaime C. ${ }^{1,4}$

1 Departamento de Biología, Facultad de Ciencias, Universidad de La Serena, Casilla 599, La Serena, Chile.

2 Departamento de Ciencias Biológicas y Químicas, Núcleo de Estudios Ambientales, Facultad de Recursos Naturales, Universidad Católica de Temuco, Casilla 15-D, Temuco, Chile.

3 Departamento de Biología Marina, Facultad de Ciencias del Mar, Universidad Católica del Norte, Casilla 117, Coquimbo, Chile.

${ }^{4}$ Instituto de Investigación Multidisciplinar en Ciencia y Tecnología, Universidad de La Serena, La Serena, Chile.

Corresponding author: Claudio Palma-Rojas cpalma@userena.cl

Cite this article as: Palma Rojas C., Jara Seguel P., García M., von Brand E., Araya Jaime C. 2019. KARYOLOGICAL STUDY IN THE CHILEAN RHATANY Krameria cistoidea HOOK. \& ARN. (KRAMERIACEAE). BAG. Journal of Basic and Applied Genetics XXX (2): 21-25.

\section{ABSTRACT}

The karyotype of the plant species Krameria cistoidea Hook. \& Arn. was studied by assessing chromosome characters such as morphology, size, and C-banding pattern. The karyotype of K. cistoidea was composed only by metacentric chromosomes in the two populations studied. The haploid set length was $51.9 \pm 2.3 \mu \mathrm{m}$ and the mean chromosome size was $8.68 \pm 0.78 \mu \mathrm{m}$. Some similarities in chromosome morphology and size can be observed among K. cistoidea and $K$. triandra, in addition to the chromosome number $2 n=12$ which is conserved within the genus. $K$. cistoidea exhibited a symmetric banding pattern with large $\mathrm{C}$-bands in the telomeres of the short and long arms of all chromosomes, except the short arm of pair 1 . The relative length of the C-bands was $23.5 \%$ of the total haploid set length. These cytological results on $\mathrm{K}$. cistoidea are the first data on quantitative karyotype morphology and C-banding patterns in the genus Krameria.

Key words: Krameria, karyotype, C-banding.

\section{RESUMEN}

El cariotipo de la especie vegatal Krameria cistoidea Hook. \& Arn., 2n=12, se estudió en individuos de dos poblaciones considerando las variables de tamaño, morfología y patrón de bandas C. La longitud del set haploide fue de 51,9 $\pm 2,3 \mu \mathrm{m}$ con un tamaño cromosómico promedio de 8,68 $\pm 0,78 \mu \mathrm{m}$. Se encontraron algunas similitudes de morfología y tamaños cromosómicos entre el cariotipo de $K$. cistoidea y el descrito para $K$. triandra, ambas con 2n=12 guarismo conservado dentro del género. Los cromosomas de $K$. cistoidea muestran un patrón simétrico de grandes bandas $\mathrm{C}$ en los telómeros de todos ellos, excepto en el brazo corto del par 1 y con una longitud relativa de los segmentos con bandas C de un $23,5 \%$ del set haploide. Estos resultados son los primeros datos cuantitativos relativos al cariotipo y patrón de bandas $\mathrm{C}$ en el género Krameria.

Palabras clave: Krameria, cariotipo, bandas-C. 


\section{INTRODUCTION}

Krameria cistoidea (Krameriaceae) Hook. \& Arn., is a plant species endemic to Chile with a center of distribution located between Huasco $\left(28^{\circ} \mathrm{S}\right)$ and Limari rivers basins $\left(30^{\circ} \mathrm{S}\right)$ in the coastal and pre-Andean slopes of a semiarid zone (Squeo et al., 2001). Along its geographical range $K$. cistoidea shares the habitat with $K$. lappacea. At present, almost 16 Krameria species constitute the monogeneric family Krameriaceae which is distributed across the Americas, but only two species are present in Chile. The taxonomic classification of Krameria has been principally based upon morphology, anatomy, pollen ultra-structure, wood anatomy and DNA sequences (Heusser, 1971; Robertson, 1973; Simpson and Skvarla, 1981; Soltis et al., 2000; Simpson et al., 2004; Carlquist, 2005). Nevertheless, since its description by Loefling in 1758 , the genus Krameria has presented a problem to taxonomists as to its placement within the dicotyledons (Robertson, 1973; Simpson and Skvarla, 1981). Currently, Krameria is considered within the Zygophyllales order together with other genera belonging to the Zygophyllaceae family (Soltis et al., 2000; Simpson et al., 2004). Historical reports have described that the roots of K. cistoidea have had a variety of uses such as medicinal herb, for liqueur production, and as an important source of dye (Muñoz, 1985). However, despite of its extraction and habitat degradation by anthropic and natural effects, information on its conservation is scarce, but this species does not meet the criteria to be considered vulnerable (Benoit, 1989; Squeo et al., 2001). Krameria species show a haploid chromosome number $\mathrm{n}=6$ (Turner, 1958; Lewis et al., 1962), which later was corroborated with the count of the diploid number 2n=12 described in K. triandra (Teppner, 1984). Recently, the chromosome number $2 \mathrm{n}=12$ was also found in $K$. cistoidea, which was complemented with data on DNA C-value (1C=9.3 pg) (Palma Rojas et al., 2017), thus supplying new cytological data for the genus. However, despite these advances, the karyotype morphology has not been described for species of the genus, and there are no reports on specific chromosome markers, for example, C-banding patterns, which show the location of constitutive heterochromatin. It is remarkable that the Chilean taxa of Krameria form part of the most southern species along the geographical range of the genus in America (Simpson et al., 2004). In this sense karyotype studies including heterochromatin location may be fundamental to understand patterns on genetic variation, genome evolution and speciation in these plants (Stebbins, 1971; Guerra, 2000; Levin, 2002; Jara Seguel et al., 2010; Jara Arancio et al., 2012; Jara Seguel and Urrutia, 2012), and may contribute significantly to establish the cytological relationships among North American and South American Krameria species, supplying also additional evidence for its taxonomic status within the Zygophyllales. For this reason, we describe the karyotype morphology and the distribution of constitutive heterochromatin in $K$. cistoidea, the most representative species of the genus present in the Chilean flora.

\section{MATERIALS AND METHODS}

Plants of Krameria cistoidea Hook. \& Arn. were collected from two naturally growing populations, in Punta Colorada ( $28^{\circ} 30^{\prime} \mathrm{S} ; 70^{\circ} 48^{\prime} \mathrm{W}$, altitude $585 \mathrm{~m}$ above sea level), and Cuesta Buenos Aires $\left(30^{\circ} 2^{\prime} \mathrm{S} ; 70^{\circ} 49^{\prime} \mathrm{W}\right.$, altitude $380 \mathrm{~m}$ above sea level), both spaced at a distance of approximately $170 \mathrm{~km}$ in Central Chile. Voucher specimens for both populations were deposited at the Herbarium of the Universidad de La Serena, La Serena, Chile (Herbario ULS). Roots of germinated seeds were pre-treated with 8 -Hydroxiquinoline $2 \mathrm{mM}$ at $7^{\circ} \mathrm{C}$ for $3 \mathrm{~h}$, fixed in ethanol-glacial acetic acid (3:1 v/v) at $4^{\circ} \mathrm{C}$ for $24 \mathrm{~h}$, and stored in ethanol $70 \%(\mathrm{v} / \mathrm{v})$ at $4^{\circ} \mathrm{C}$ until use. To determine chromosome morphology, the roots were stained with Feulgen reaction and chromosome preparations were made by squashing the root tips. For Giemsa C-banding, the fixed roots were washed in distilled water and treated with a solution of pectinasecellulase (Fluka; $2: 1 \mathrm{w} / \mathrm{w})$ at $7.5 \%(\mathrm{w} / \mathrm{v})$ in $0.2 \mathrm{M}$ citrate buffer $\mathrm{pH} 4.2$ at $37^{\circ} \mathrm{C}$ for 30 minutes. The procedure used to obtain C-bands was based on the technique described by Summer (1972). In photomicrographs of ten metaphase plates (Feulgen preparations) obtained from ten plants, the short and long arms were measured and the total relative length of each chromosome pair (expressed as percentage of the total haploid set length) was calculated. Additionally, total haploid set length (THL in $\mu \mathrm{m}$ ), and mean chromosome size (in $\mu \mathrm{m}$ ) were estimated. The karyotype was constructed according to decreasing chromosome length and chromosome morphology, using the nomenclature by Levan (Levan et al.,1964; Spotorno, 1985). The C-bands were classified according to their chromosome location as centromeric, pericentromeric, interstitial or telomeric. Relative length values of C-bands (RLC) were calculated by using the follow equation described by Linde-Larsen et al. (1980): RLC= (C-band length of the haploid set / Total haploid set length) $\mathrm{x} 100$.

\section{RESULTS}

The Feulgen stained karyotype of $K$. cistoidea is shown in Figure 1a, and chromosome measurements are presented in Table 1. Both populations of K. cistoidea studied here showed a diploid chromosome number of $2 \mathrm{n}=12$, with a 
karyotype composed only by metacentric chromosomes. Satellites and secondary constrictions were not observed in these chromosomes. The chromosomes of K. cistoidea are large, with a mean chromosome size of $8.68 \pm 0.78$ $\mu \mathrm{m}$ and a total haploid set length of $51.9 \pm 2.3 \mu \mathrm{m}$.

The C-banded karyotype of $\mathrm{K}$. cistoidea is shown in Figure 1b. K. cistoidea exhibited C-bands located in the telomeres of the short and long arms of all chromosomes, except the short arm of pair 1 . These large regions of constitutive heterochromatin in the karyotype were concurrent with the presence of many conspicuous and large chromocenters in the interphase nuclei (Figure 2). Homologous chromosomes exhibited similar C-banding patterns and pairing was possible. The centromeres were also evident in all chromosomes. The relative length of the $\mathrm{C}$-bands was equivalent to $23.5 \%$ of the total haploid set length. Polymorphism in C-banding pattern was not observed in both studied populations.

\begin{tabular}{lcccccc}
\hline $\begin{array}{l}\text { Chromosome } \\
\text { pair }\end{array}$ & $\begin{array}{c}\text { SA (\%) } \\
(\text { Mean } \pm \text { SD) }\end{array}$ & $\begin{array}{c}\text { LA (\%) } \\
(\text { Mean } \pm \text { SD) }\end{array}$ & $\begin{array}{c}\text { TL }(\%) \\
(\text { Mean } \pm \text { SD) }\end{array}$ & $\begin{array}{c}\text { CS }(\boldsymbol{\mu m}) \\
(\text { Mean } \pm \text { SD) }\end{array}$ & Cl & Type \\
\hline 1 & $8.92 \pm 0.43$ & $10.19 \pm 0.67$ & $19.11 \pm 0.96$ & $10.0 \pm 0.70$ & $0.47 \pm 0.03$ & $\mathrm{~m}$ \\
2 & $8.57 \pm 0.25$ & $9.40 \pm 0.5$ & $17.97 \pm 0.66$ & $9.3 \pm 0.45$ & $0.48 \pm 0.02$ & $\mathrm{~m}$ \\
3 & $7.56 \pm 0.42$ & $9.19 \pm 0.45$ & $16.74 \pm 0.65$ & $8.6 \pm 0.50$ & $0.45 \pm 0.02$ & $\mathrm{~m}$ \\
4 & $7.48 \pm 0.35$ & $8.67 \pm 0.64$ & $16.15 \pm 0.49$ & $8.4 \pm 0.43$ & $0.46 \pm 0.01$ & $\mathrm{~m}$ \\
5 & $6.89 \pm 0.6$ & $8.56 \pm 0.61$ & $15.45 \pm 0.49$ & $8.0 \pm 0.40$ & $0.45 \pm 0.04$ & $\mathrm{~m}$ \\
6 & $6.51 \pm 0.5$ & $8.06 \pm 0.33$ & $14.58 \pm 0.53$ & $7.6 \pm 0.39$ & $0.45 \pm 0.03$ & $\mathrm{~m}$ \\
\hline
\end{tabular}

\section{if if if is if is 1 2 \\ 4}

Figure la. Karyotype of Krameria cistoidea, $2 \mathrm{n}=12$. Feulgen stain. Bar=10 $\mu \mathrm{m}$.
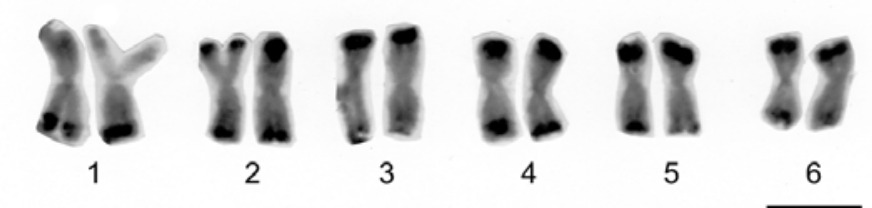

Figure 1b. Karyotype of Krameria cistoidea with Giemsa C-banding. Bar=10 $\mu \mathrm{m}$
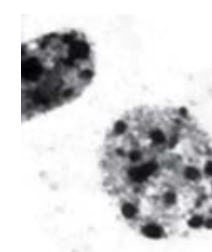

Y.
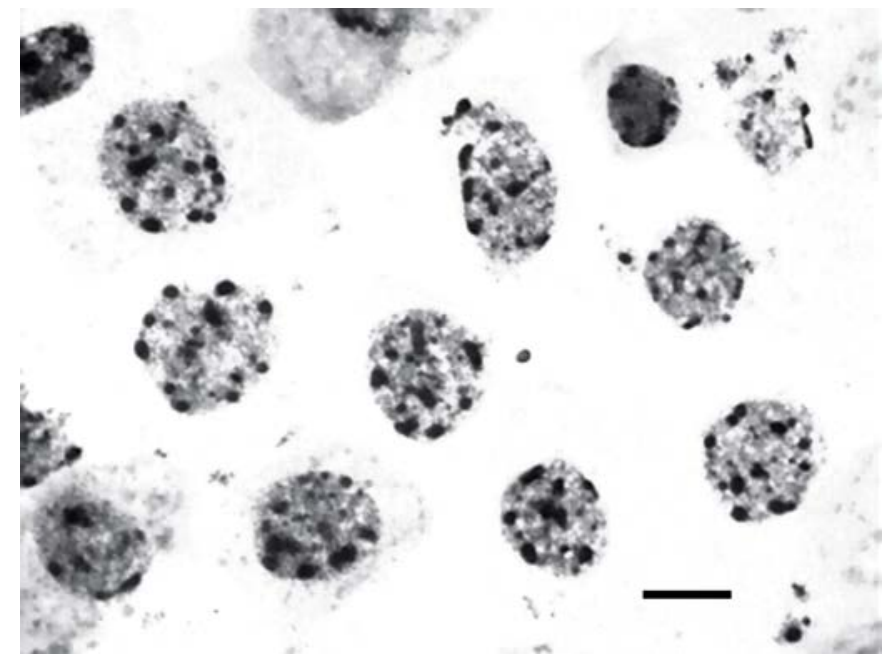

Figure 2. Meristematic interphase nuclei of Krameria cistoidea, with many chromocenters. Bar=10 $\mu \mathrm{m}$. 


\section{DISCUSSION}

The results of this study corroborate the chromosome number of $2 \mathrm{n}=12$ described previously for $\mathrm{K}$. cistoidea (Palma Rojas et al., 2017), which is also similar to other six species of the genus described some decades ago (Turner, 1958; Lewis et al., 1962; Teppner, 1984) (Table 2). In this work, quantitative karyotype morphology of one Chilean species of the genus Krameria, K. cistoidea (Figure 1a, Table 1) is reported, which is additional to the data on chromosome number and $2 \mathrm{C}$-value previously reported for one population of the same species (Cuesta El Churque population, Chile) (Palma Rojas et al., 2017). The karyotype of K. cistoidea was uniform among both populations studied. However, at the interspecific level differences in chromosome morphology and size were observed between the karyotype of $K$. cistoidea and K. triandra from Perú. K. cistoidea, with a metacentric and unimodal karyotype, had all chromosomes with a centromeric index CI between 0.45 and 0.48 (mean $\mathrm{CI}=0.46 \pm 0.012$ ), and a chromosome size that varied between 7.63 and $10.0 \mu \mathrm{m}$ with an average size of 8.68 $\mu \mathrm{m}$. In the case of $K$. triandra the centromeres are located in median or sub-median region as determined by mean qualitative analysis, and the range of chromosome size varied between $10 \mu \mathrm{m}$ and $14 \mu \mathrm{m}$ (Teppner, 1984). Such interspecific differences in chromosome morphology and size among these Krameria species may be preliminary evidence on the occurrence of mechanism of chromosome rearrangements (e.g., inversions, duplication, deletions) during the evolution of the genus as it has been described in various other Angiosperm groups (Stebbins, 1971; Levin, 2002). Future comparative karyotype studies in Krameria may give more evidence to corroborate this hypothesis.

Table 2. Chromosome number for Krameria species. n, gametic chromosome number; 2 n, somatic chromosome number.

\begin{tabular}{|c|c|c|c|}
\hline Species & $\mathbf{n}$ & 2n & Reference \\
\hline Krameria cistoidea Hook \& Arn & - & 12 & Palma-Rojas et al. (2017) \\
\hline K. cistoidea & - & 12 & Present study \\
\hline K. grayi Rose \& Painter & 6 & - & Weedin \& Powel (1978) \\
\hline \multirow[t]{4}{*}{ K. lanceolata Torr } & 6 & - & Lewis et al. (1962) \\
\hline & - & 12 & Kondo et al. (1981) \\
\hline & 6 & - & Spellenberg (1986) \\
\hline & 6 & - & Freeman \& Brooks (1988) \\
\hline K. parvifolia Benth & 6 & - & Weedin \& Powel (1978) \\
\hline K. parviflora var. glandulosa & 6 & - & Ward (1983) \\
\hline K. triandra Ruiz \& Pav & - & 12 & Teppner (1984) \\
\hline
\end{tabular}

The chromosome location of constitutive heterochromatin is another additional genome character for the first time studied here for one Krameria species. The banding pattern of both populations of K. cistoidea exhibited large blocks of constitutive heterochromatin, located only in telomeric regions in the short and long arms of the metacentric chromosomes with a symmetrical banding (Greilhuber, 1984). However, due to the large chromosome size (higher to $5.0 \mu \mathrm{m}$ according to Guerra, 2000), it is possible that the entire constitutive heterochromatin content of the species has not been revealed through this method, as it has also been described in other plant groups (Schweizer and Loidl, 1987; Buitendijk and Ramanna, 1996; Guerra, 2000). In this way, the information on C-bands in Krameria can be a fundamental knowledge for the application of other modern molecular techniques (FISH, GISH, $\mathrm{CMA}_{3}$, and/ or DAPI) focused on describing genome organization, as it has been done in other flowering plants in which complex C-banding patterns have been performed (Joachimiak et al., 1997; Guerra, 2000; Zhou et al., 2003; She et al., 2007; Hamon et al., 2009).

Within the Zygophyllales, comparative karyological studies have been made within the genus Bulnesia belonging to Zygophyllaceae. Bulnesia species with highest (B. retama $2 \mathrm{C}=4.5 \mathrm{pg}$, and $B$. chilensis $2 \mathrm{C}=2.9$ pg) and lowest $2 \mathrm{C}$-values (B. sarmientoi $2 \mathrm{C}=0.7$ pg) possess the most asymmetric karyotype (with metacentric, submetacentric, subtelocentric and telocentric chromosomes), whereas species with intermediate $2 \mathrm{C}$-values (B. foliosa and B. schickendantzii, both with approximately $2 \mathrm{C}$-Values of $1.1 \mathrm{pg}$ ) possess most symmetric karyotypes (with metacentric and submetacentric chromosomes) (Poggio et al., 1986). In addition, the species with the highest $2 \mathrm{C}$-values ( $B$. retama and $B$. chilensis) have the highest constitutive heterochromatin content as reveled by $\mathrm{C}$-banding patterns (Poggio and Hunzkiker, 1986). All these karyotype studies in Bulnesia havebeen useful to elucidate interesting evolutionary trends within the genus. In the case of Krameria, the quantitative karyotype characters described here for $\mathrm{K}$. cistoidea, as well as additional data on C-banding and 2C-values, should be studied in other Krameria species from both hemispheres, thus revealing the mechanisms of chromosome evolution that have occurred in this genus along its distribution range. On the other hand, phylogenetic relationships among Krameriaceae and Zygophyllaceae should be carried out including all genome data that could be feasible to obtain (e.g., cytogenetic, molecular), thus providing valuable data to clarify the taxonomical relationship of both families within the order Zygophyllales, which is still confuse. 


\section{REFERENCES}

Benoit I. (1989) Libro Rojo de la Flora Terrestre de Chile. Corporación Nacional Forestal (CONAF - Chile).

Buitendijk J., Ramanna M. (1996) Giemsa C-banded karyotypes of eigth species of Alstroemeria L. and some of their hybrids. Ann. Bot. 78: 449-457.

Carlquist S. (2005) Wood anatomy of Krameriaceae with comparisons with Zygophyllaceae: Phylesis, ecology and systematics. Bot. J. Linn. Soc. 149: 257-270.

Freeman C., Brooks R. (1988) Documented plant chromosome numbers 1988: 1 . Chromosome counts for North American plants. SIDA 13: 241-250.

Greilhuber J. (1984) Chromosomal evidence in taxonomy. In: Heywood V.H., Moore D.M. (Eds.) Current concepts in plant taxonomy. London, Academic Press, pp. 157-180.

Guerra M. (2000) Patterns of heterochromatin distribution in plant chromosomes. Gen. Mol. Biol. 23 (4): 1029-1041.

Hamon P., Siljak Yakovlev S., Srisuwan S., Robin O., Poncet V., Hamon S., De Kochko A. (2009) Physical mapping of rDNA and heterochromatin in chromosomes of 16 Coffea species: A revised view of species differentiation. Chromosome Res. 17: 291304.

Heusser C. (1971) Pollen and spores of Chile. Arizona Press, Tucson, USA.

Jara Arancio P., Jara Seguel P., Palma Rojas C., Arancio G., Moreno R. (2012) Karyological study in fifteen Leucocoryne taxa (Alliaceae). Biología 67 (2): 289-295.

Jara Seguel P., Zúñiga C., Romero Mieres M., Von Brand E. (2010) Karyotype study in Luzuriaga radicans (Liliales: Luzuriagaceae). Biología 65 (5): 813-816.

Jara Seguel P., Urrutia J. (2012) Cytogenetics of Chilean Angiosperms: Advances and prospects. Rev. Chil. Hist. Nat. 85: 1-12.

Joachimiak A., Kula A., Johachimiak G. (1997) On heterochromatin in karyosystematic studies. Acta Biol. Kracov. Bot. 39: 69-77.

Kondo K., Segawa M., Musselman L., Mann W. (1981) Comparative ecological study of the chromosome races in certain root parasitic plants of the southeastern USA. Bol. Soc. Brot. 2 (52): 793-807.

Levan A., Fredga K., Sandberg A. (1964) Nomenclature for centromeric position on chromosomes. Hereditas 52: 201-220.

Levin D. (2002) The role of chromosome change in plant evolution. New York: Oxford University Press.
Lewis W., Stripling H., Ross R. (1962) Chromosome numbers for some angiosperms of the Southern United States and Mexico. Rhodora 64: 147-161.

Linde Laursen I., Von Bothner R., Jacobsen N. (1980) Giemsa C-banding in Asiatic taxa of Hordeum section Stenostachys with notes on chromosome morphology. Hereditas 93: 235-254.

Muñoz M. (1985) Flores del Norte de Chile 1. DIBAM - Municipalidad La Serena, Chile.

Palma Rojas C., Jara Seguel P., García M., von Brand E. (2017) Nuclear DNA content and chromosome number of Krameria cistoidea Hook. \& Arn. (Krameriaceae). Gayana Bot. 74 (1): 128-130.

Poggio L., Wulff A., Hunziker J. (1986) Chromosome size, nuclear volume and DNA content in Bulnesia (Zygophyllaceae). Darwiniana 27 (1-4): 25-38.

Poggio L., Hunziker J. (1986) Nuclear DNA content variation in Bulnesia. J. Hered. 77 (1): 43-48.

Robertson K. (1973) The Krameriaceae in the Southeastern United States. J. Arnold Arbor. 54: 322-327.

She C., Liu J., Diao Y., Hu Z., Song Y. (2007) The distribution of repetitive DNAs along chromosomes in plants revealed by selfgenomic in situ hybridization. J. Genet. Genom. 34 (5): 437-448.

Squeo F., Arancio G., Gutierrez J. (2001) Libro Rojo de la Flora Nativa y de los Sitios Prioritarios para su Conservación: Región de Coquimbo. Editorial Universidad de La Serena (Chile).

Schweizer D., Loidl J. (1987) A model for heterochromatin dispersion and the evolution of C-band patterns. Chromosomes Today 9: 61-74

Simpson B., Helfgott D., Weeks A., Larkin L. (2004) Species relationships in Krameria (Krameriaceae) based on ITS sequences and morphology: Implications for character utility and biogeography. Syst. Bot. 29: 97-108.

Simpson B., Skvarla J. (1981) Pollen morphology and ultrastructure of Krameria (Krameriaceae): Utility in question of intrafamilial and interfamilial classification. Am. J. Bot. 68 (2): 277-294.

Soltis D., Soltis P., Chase M., Mort M., Albach D., Zanis M., Savolainen V., Hahn W., Hoot S., Fay M., Axtell M., Swensen S., Prince I., Kres W., Nixon K., Farris J. (2000) Angiosperm phylogeny inferred from $18 \mathrm{~S}$ rDNA, rbcL, and atpB sequences. Bot. J. Linn. Soc. 133: 381461.

Spellenberg R. (1986) Chromosome number reports. Taxon 90: 35-197.
Spotorno A. E. (1985) Conceptos y métodos en cariología descriptiva y comparada. In: Fernandez-Donoso R. (ed). El núcleo, los cromosomas y la evolución. UNESCO, Santiago, pp.135-163.

Stebbins G. (1971) Chromosomal evolution in higher plants. Edward Arnold Publishing, London.

Summer A. (1972) A simple technic for demonstrating centromere heterocromatin. Exp. Cell Res. 75: 304-306.

Teppner H. (1984) Karyology von Krameria triandra (Krameriaceae). Kurzfassungen (der Beiträge). Botaniker-Tagung, Deutscher Botanische Gesellschaft Wien, 1984: pp. 71.

Turner B. (1958) Chromosome numbers in the genus Krameria: evidence for familial status. Rhodora 60: 101-106

Ward D. (1983) IOPB chromosome number reports LX. Taxon 32: 510-511.

Weedin J., Powell A. (1978) In IOPB chromosome number reports LX. Taxon 27: 223-231.

Zhou S., De Jeu M., Visser R., Kuipers A. (2003) Characterization of distant Alstroemeria hybrids: application of highly repetitive DNA sequences from A. ligtu ssp. ligtu. Ann. Appl. Biol. 142: 277-283. 



\title{
VARIANTES PATOGÉNICAS DE TP53 RELACIONADAS CON CÁNCER
}

\author{
Rosero C.Y. ${ }^{*}$, Mejia L.G.', Corredor M. ${ }^{2,3}$
}

1 Interdisciplinary Research Group in Health and Disease, Medicine Faculty, Universidad Cooperativa de Colombia, San Juan de Pasto, Nariño, Colombia.

${ }^{2}$ Genetics and Biochemistry of Microorganisms, Natural and Exact Sciences Faculty, Biology Institute, Universidad de Antioquia, Medellín colombia.

3 Genetics, Regeneration and Cancer, GRC, Natural and Exact Sciences Faculty, Biology Institute, Universidad de Antioquia, Medellín, Colombia.

Corresponding author:

Carol Yovanna Rosero Galindo

carol.roserog@campusucc.edu.co

\section{Cite this article as:}

Rosero C.Y., Mejia L.G., Corredor M. 2019. TP53 PATHOGENIC VARIANTS RELATED TO CANCER. BAG. Journal of Basic and Applied Genetics XXX (2): $27-40$.

Received: 07/12/2019

Revised version received: 10/25/2019 Accepted: 11/07/2019

General Editor: Elsa Camadro DOI: 10.35407/bag.2019.xxx.02.03 ISSN online version: 1852-6233

\begin{abstract}
TP53 or P53 is a tumor suppressor gene known as the "genome guardian", responsible for inducing cell response to DNA damage, by stopping the cell cycle in case of mutation, activating DNA repair enzymes, initiating senescence and activation of apoptosis. Mutations in the gene sequence can cause non-synonymous mutations or errors in the reading frame by insertion, deletion or displacement of nucleotides: e.g., c.358A $>\mathrm{G}$ mutation in exon 4 and variants located in exons 9 and 10 of the TD domain. Therefore, in this review, we will see that changes in the reading frame, including the loss of one or two base pairs could prevent accurate transcription or changes in the structure and function of the protein, and could completely impair reparation function. These changes promote self-sufficiency in growth signaling, insensitivity to anti-growth signals, and evasion of apoptosis, resulting in limitless replication and induction of metastatic angiogenesis, generating as a consequence the proliferation of tumor, neoplastic, and lymphoid cells. Taking into account the importance of TP53 in the regulation of the cell cycle, the objective of this review is to update information related to the role of this gene in the development of cancer and the description of genetic variations.
\end{abstract}

Key words: Neoplasms, nuclear phosphoprotein p53, Tumor Suppressor, mutation, Clinvar, Uniprot

\section{RESUMEN}

TP53 o P53 es un gen supresor de tumores conocido como el "guardián del genoma", encargado de inducir la respuesta de la célula ante el daño del ADN, deteniendo el ciclo celular en caso de mutación, activando enzimas de reparación del ADN, iniciando el proceso de senescencia celular y activación de la apoptosis. Las mutaciones en la secuencia del gen pueden originar mutaciones no sinónimas o errores en el marco de lectura por la inserción, deleción o desplazamiento de nucleótidos: ejemplo, mutación c.358A>G en el exón 4 y variantes que se albergan en los exones 9 y 10 del dominio TD. Por lo tanto en esta revisión examinaremos cambios en el marco de lectura, incluyendo la pérdida de una o dos pares de bases, que podrían impedir la exacta transcripción o cambiar la estructura y función de la proteína o perjudicar completamente la función de reparación. Tales cambios promueven la auto-suficiencia en la señal de crecimiento, la insensibilidad a señales anticrecimiento y la evasión de la apoptosis, lo que resulta en la replicación ilimitada y la inducción de angiogénesis metastásica, generando como consecuencia la proliferación de células tumorales, neoplásicas y linfoides. Teniendo en cuenta la importancia del TP53 en la regulación del ciclo celular, el objetivo de la presente revisión es actualizar la información relacionada con el papel de este gen en el desarrollo de cáncer y la descripción de las variaciones genéticas.

Palabras clave: Neoplasma, fosfoproteína nuclear p53, supresor de tumor, mutation, Clinvar, Uniprot. 


\section{TP5 3 IN THE DEVELOPMENT OF CANCER}

Cancer is the result of the accumulation of multiple alterations in the genes that regulate cell growth and are considered critical for the progressive transformation of non-cancerous cells to malignant cells (Sánchez, 2006; Pierce, 2009; Herrera et al., 2010; Risueño, 2012). Some alterations include point mutations, chromosome disruption, repair interruption, epigenetic alterations, and oncogene rearrangements as well as loss or alteration in the function of tumor suppressor genes (Roa et al., 2000; Pierce, 2009).

Among the tumor suppressor genes most commonly altered in various cancers, the tumor suppressor gene TP53 is notable. TP53 has been reported as a viable genetic marker for the diagnosis and prognosis of various types of tumors (Ramírez et al., 2008). The TP53 gene product is a tumor suppressor protein that is also known as tumor protein P53, P53 cellular antigen tumor (UniProt), P53 phosphoprotein, P53 suppressor tumor, NY-CO13 antigen, or transformation-related protein 53 (TRP53). It corresponds to a crucial orthologous protein that prevents cancer in several organisms. Colloquially, it is termed the "guardian of the genome", because it prevents mutations and maintains genomic stability (Isobe et al., 1986; Kern et al., 1991; McBride et al., 1986; Bourdon, 2007).

The International Cancer Genome Consortium established that TP53 is the most frequently mutated gene $(>50 \%)$, indicating that it plays a crucial role in the prevention of cancer formation (Surget et al., 2013).

\section{STRUCTURE-FUNCTION RELATIONSHIP OF P 53}

TP53 is located on the short arm of chromosome 17 at position 17p13.1, extending more than $20 \mathrm{~kb}(20,000$ bases, depending on the variant), with the first noncoding exon and a first long intron of $10 \mathrm{~kb}$. The coding sequence covers from exon 2 to the initial part of exon 11 and codes for a $53 \mathrm{kDa}$ nuclear phosphoprotein called P53 that is divided into three regions and domains, each with a specific function (Alpízar et al., 2005; Rangel et al., 2006; Gallego et al., 2010; López, 2011). The conformation of the tetramer structure (Figure 1) and active regions of the protein (Figure 2 ) are presented below:

The $\mathrm{p} 53$ protein consists of five main domains:

1. The amino-terminal region, which carries the activation domains of transcription: $\mathrm{AD} 1$ and $\mathrm{AD} 2$ (amino acids 1-42:43-63).

2. The next region which contains many amino acid repeats of proline, called $\mathrm{PRD}$, or a domain rich in proline (amino acids 64-91).

3. The central region (amino acids 101-306) which corresponds to the DNA-specific sequence binding domain (DBD), being the region where the highest number of mutations in human cancer has been recorded.

4. The carboxyl-terminal region, which contains the tetramer domain TD (amino acids 334-356), and

5. The basic or alkaline domain BD (amino acids 364393); these domains participate in the formation of dimers and tetramers where the tetrameric complex is active in transcriptional regulation.

The conformation of the tetramer structure and active regions of the protein are presented in Figures 1 and 2.

As a tumor suppressor, $\mathrm{P}_{53}$ is essential for preventing inappropriate cell proliferation and maintaining the integrity of the genome after genotoxic stress. Intracellular and extracellular stimuli such as DNA damage (including UV radiation, cytotoxic drugs, therapeutic chemical agents, and viruses), thermal shock, hypoxia, and oncogenic overexpression activate P53 protein as a regulatory mechanism to induce various biological responses (Bai and $\mathrm{Zhu}, 2006$ ). Activation of $\mathrm{P} 53$ involves an increase in its protein level as well as qualitative changes through a broad posttranslational modification, which results in activation of the P53-target gene complex; in this way, it acts as a sequence-specific transcription factor and regulates the expression of different genes that modulate various cellular processes in response to different types of stress. The genes activated by P53 are functionally diverse and participate in responses such as cell cycle control, cell survival, apoptosis, and senescence (Joerger, 2008).

In this context, the $\mathrm{P} 53$ protein can stop the cell cycle in phases G1 and G2 to provide additional time for cells to repair damage to the genome before entering the critical stages of DNA synthesis and mitosis. In the P53 signaling pathway in G1 (Figure 3), P21 protein blocks the cell cycle in the G1-S transition, joining the cyclin-CDK complexes (cyclin D/CDK4 and cyclin E/CDK2) responsible for driving the cell to the S-phase and avoiding activation of the transcription factor of the E2F family (elongation factor 2). By inhibiting the complexes, phosphorylation of $\mathrm{RB}$ (protein of retinoblastoma) is prevented; since this protein is necessary to start the $\mathrm{S}$-phase, this blocks the progression of the cell cycle (Tomoak et al., 2001; Ballesteros et al., 2007). The genes involved in stopping the cycle in G2 are the REPRIMO and 14-3-35, members of a family of structural proteins. These genes sequester the cyclin B1-CDK1 complex outside the nucleus, which maintains the blockade in G2 Ballesteros et al., 2007; Saavedra, 2015). The 14-3-3s protein interacts with CDKs and can inhibit their activity to block the progression of the cell cycle; likewise, it regulates P53 and functionally increases its stability and reinforces its transcriptional activity (Zhang 2004). By contrast, the protein encoded by the target gene GADD45 interacts with the CDC2 protein to block its kinase activity through the inhibitory 
domain located in the central region of the protein (amino acids 65-84) that substantially contributes to the suppression of growth, thereby inducing arrest of the cell cycle (Saavedra, 2015).

As a guardian of the genome, $\mathrm{P} 53$ monitors cellular stress and, in tissues where stress can generate severe and irreparable damage, P53 can initiate apoptosis to eliminate damaged cells (Joerger, 2008; Harris, 1996) (Figure 3). The intrinsic or mitochondrial pathway of apoptosis is activated in response to DNA damage, a defective cell cycle, hypoxia, or other severe stress environments and is characterized by the release of proapoptotic molecules such as cytochrome $\mathrm{C}$. The pathway is tightly regulated by a group of pro-apoptotic specifictissue proteins, including BAX, NOXA, and PUMA, that act by promoting the release of cytochrome $C$ from mitochondria to the cytoplasm (Yakovlev, 2004). After cytochrome $\mathrm{C}$ is released, it interacts with the activating factor of apoptosis activating proteases (APAF-1), which is also regulated by $\mathrm{P} 53$, to initiate a proteolysis cascade by proteins caspase (Rojas, 2009). Next, together with other mitochondrial proteins like SMAC/DIABLO that bind apoptosis inhibitory proteins (IAPs), it neutralizes their antiapoptotic activity, triggering a process of DNA fragmentation and cellular disorganization that leads to the death of the affected cell (Adrain and Creagh, 2001).

An alternative route through which $\mathrm{P} 53$ induces apoptosis via mitochondria is the activation of the expression of genes involved in increasing levels of reactive oxygen species like PIG3, an oxidoreductase enzyme that generates reactive oxygen species and whose expression is involved in the induction of apoptosis (Lee et al, 2010). By contrast, the extrinsic pathway, which promotes the sensitization of cells against signs of death, induces the expression of specific death receptors independently of the mitochondrial or intrinsic pathway; these death receptors include the FAS/APO-1/CD95 receptor and KILLER/DR5 receiver. The $\mathrm{P} 53$ protein also induces expression of the growth factor-3 interaction protein IGF1 (IGF1-BP3) that can bind to IGF-1 and IGF-2 (growth factors) and prevent its access to the IGFR1 receptor, thereby blocking signals from survival (Rojas, 2009).

In addition to the above-described functions, P53 mediates DNA repair processes and damage prevention through regulation of GADD45, P48, and DNA polymerase B (Uramoto et al., 2006). GADD45 plays an important role in binding to damaged DNA and, in this way, makes it available to the repair machinery. In addition, its binding to PCN -a nuclear antigen of cells under repair, the subunit of DNA polymerase D- has been described, causing inhibition in DNA synthesis. P53 also regulates transcription of the $P_{53} R 2$ gene, which plays a crucial role in DNA repair after DNA damage and encodes a small subunit of ribonucleotide reductase (RNR). This ribonucleotide reductase enzyme catalyzes the reduction of ribonucleotides diphosphate to the corresponding deoxyribonucleoside diphosphate, resulting in an equilibrium of the supply of dNTPs for DNA replication and repair (Uramoto et al., 2006).

Lastly, P53 participates in the signaling pathway of cellular senescence (Figure 3), which comprises irreversible loss of the ability to divide, initiated in response to cell stress and damage. P53-induced senescence is the permanent arrest of the cell cycle, characterized by specific changes in gene expression. The activity of $\mathrm{P} 53$ and its expression levels increase when cells senesce. One cause of $\mathrm{P}_{53}$ activation seems to be an increase in the expression of $\mathrm{P} 14$, a tumor suppressor that stimulates P53 activity because it sequesters MDM2, which facilitates the degradation of the $\mathrm{P} 53$ protein. In this way, $\mathrm{P} 14$ prevents negative feedback regulation of $\mathrm{P} 53$ via MDM2. Another potential cause of increased P53 activity is the tumor suppressor of promyelocytic leukemia (PML), which interacts with an acetyltransferase (CBP/ P300) that acetylates P53 and stimulates its activity (Bai and Zhu, 2006; Joerger, 2008).

In addition to these functions as a guardian of the genome, recent studies suggest that P53 controls additional processes that contribute to its primary function. Among these, P53 can modulate autophagy, alter metabolism, repress pluripotency and cell plasticity, and facilitate a form of iron-dependent cell death known as ferroptosis. The variety of P53 functions is anchored to its ability to control a large set of target genes (Kastenhuber and Lowe, 2017).

Cellular metabolism is controlled by $\mathrm{P} 53$ and is currently a focus of growing research interest. The set of metabolic target genes controlled by P53 affects many individual processes; it has been reported that $\mathrm{P}_{53}$ increases catabolism of glutamine, supports antioxidant activity, decreases lipid synthesis, increases oxidation of fatty acids, and stimulates gluconeogenesis. However, P53 may have opposite effects in the same metabolic processes, such as inhibiting glycolysis by attenuating glucose uptake or suppressing the expression of glycolytic enzymes in breast and lung cancer cells (Kastenhuber and Lowe, 2017).

Additionally, it has been reported that Wild-type P53 negatively regulates lipid synthesis and glycolysis in normal and tumor cells, and positively regulates oxidative phosphorylation and lipid catabolism. A polymorphism in the coding region of $\mathrm{P} 53$ in codon 72 , which codes for either proline (P72) or arginine (R72), can affect the function of the protein. In response to DNA damage, the $\mathrm{P} 72$ variant of $\mathrm{P} 53$ predominantly triggers cell cycle arrest, whereas the R72 variant predominantly induces cell death or apoptosis. Despite these differences in function, the variant of codon 72 has not been systematically associated with cancer susceptibility. By contrast, this polymorphism is significantly associated with a higher body mass index and risk of diabetes in studies of humans (Gnanapradeepan et al., 2018). 


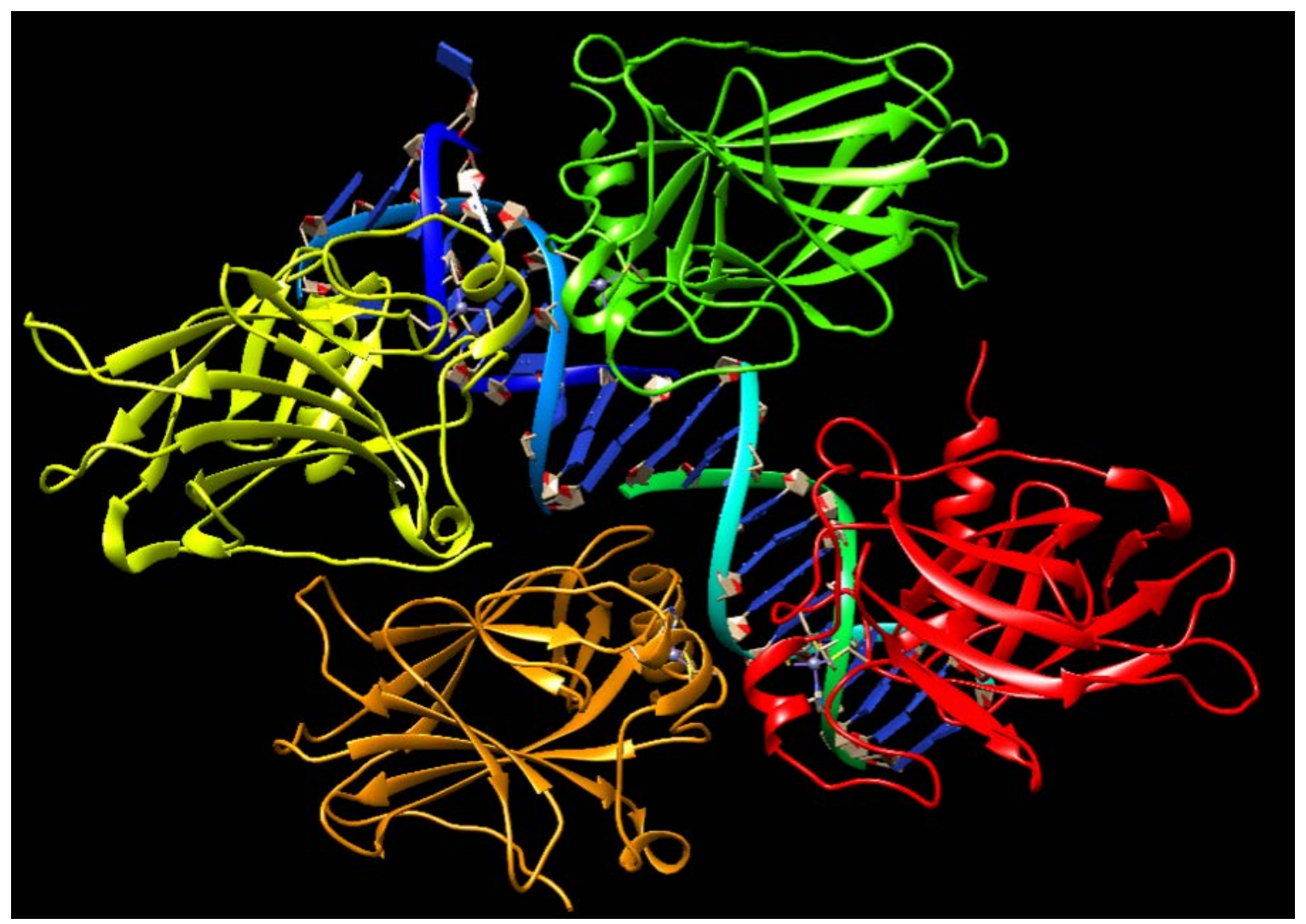

Figure 1. Formation of P53 tetramers on the DNA seen by Chimera 3,4. The structure of PDB (http://www.rcsb.org/pdb/), assembly 2AC0 developed by Kitayner et al., 2006.

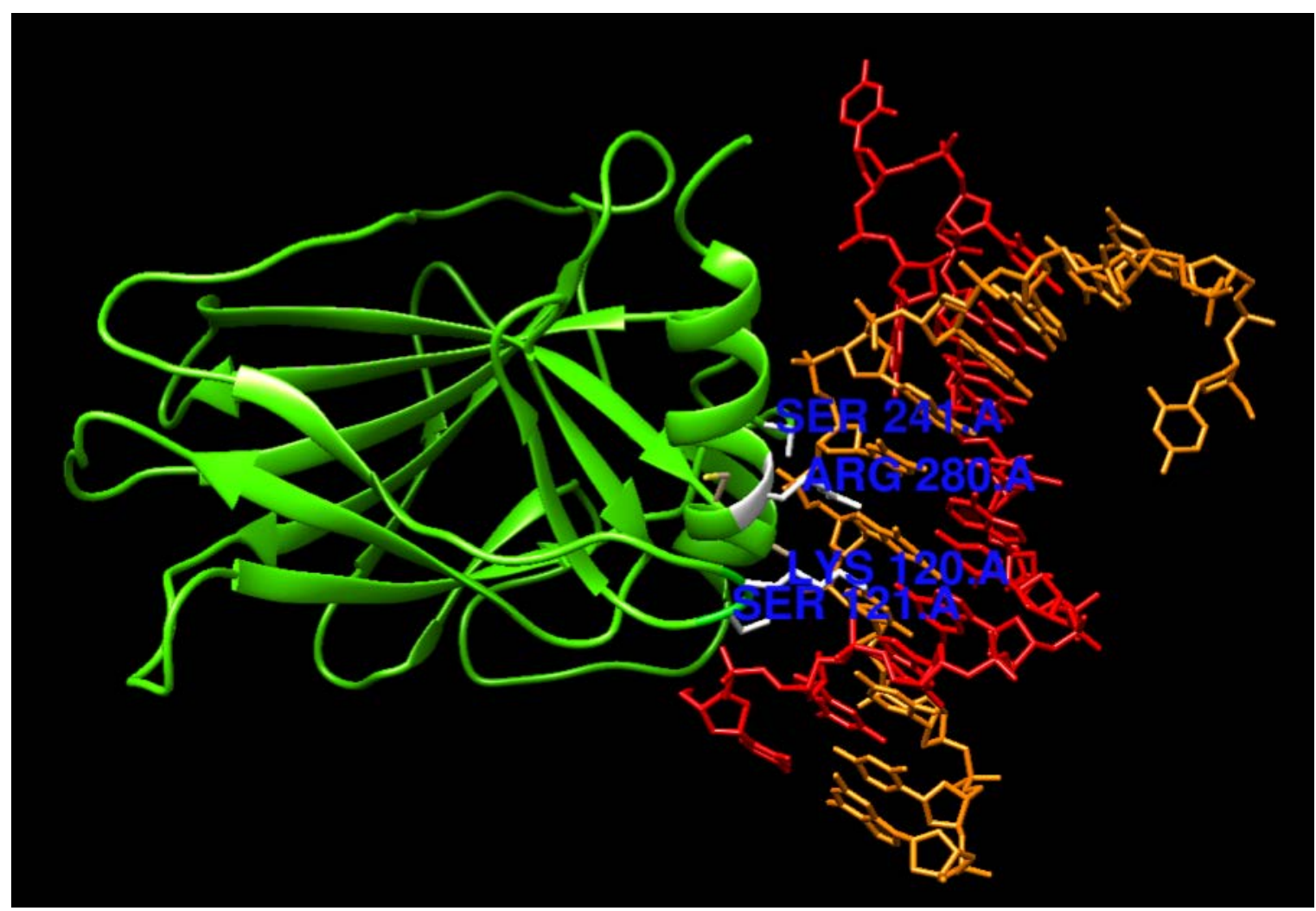

Figure 2. Some amino acids of the active protein domain with DNA, as seen by Chimera (Pettersen et al., 2004) 3,4. Lysine-120 and Serine-121 (zhao et al., 200l; Joerger et al., 2004), Serine-24l (Sjoeblom et al., 2006; Rodrigues et al., 1990); and Arginine 280 (Bartek et al., 1990; Qin et al., 2015). 


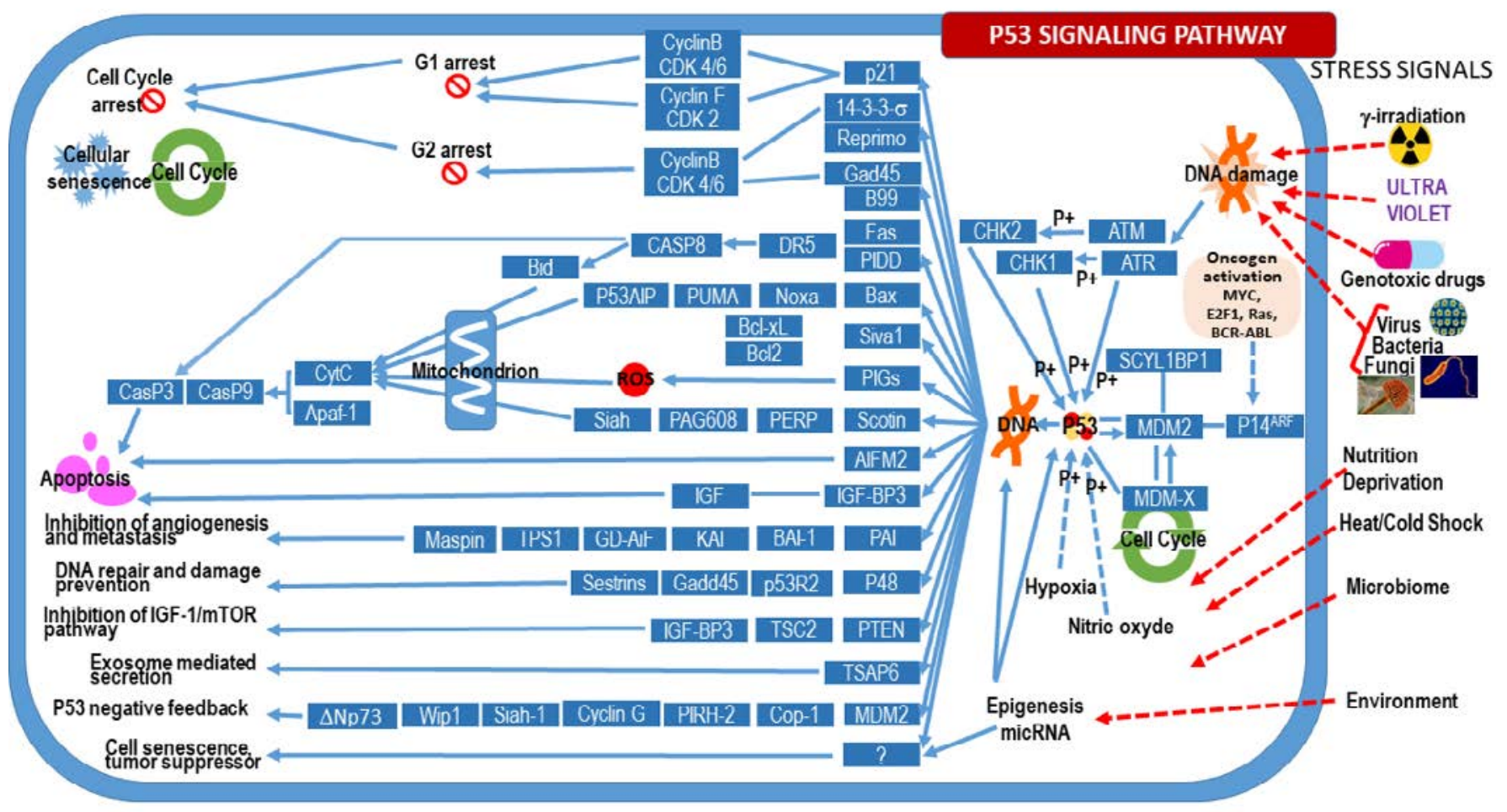

Figure 3. Scheme of signaling pathways of the p53 protein. Taken from the KEGG database assembled by the Keneshisa laboratory. Reworked in, Cell Designer 4.4 of System Biology Institute (Funahashi et al, 2003). The inclusion of virus, bacteria, fungi, epigenesis, micRNA, unknown gene (?) and its pathway to cell senescence, tumor suppressor target are original of this article and is not found in the KEGG database, which is supported by current publications (Bhardwaj et al. , 2015; Yang \& Lu, 2015).

\section{VARIATIONS}

Since the implementation of Sanger sequencing and with the advent of NGS (Next Generation Sequencing) technologies, thousands of tumors have been sequenced, generating information on the prevalence and kind of TP53 mutations in various types of cancer (Bouaoun et al., 2016).

Most mutations in TP53 occur in the central DNAbinding domain and result in an inactivation of the function as a transcription factor. In experimental contexts, some non-synonymous mutations have been associated with a dominant-negative inhibition of the wild 553 protein and/or gain of oncogenic function in the absence of the normal p53 protein (Quintela et al., 2001; Donehower et al., 2019). Likewise, such mutations often make $\mathrm{p} 53$ resistant to proteolytic degradation by ubiquitin ligases E3, such as MDM2, ensuring high levels of stable mutant p53 protein (Donehower et al., 2019).

Current evidence indicates that alterations of $\mathrm{P}_{53}$ at the gene level occur late in the pathogenesis of cancer and that the most frequent mechanism of inactivation corresponds to mutation of one allele followed by loss of the remaining allele through deletion on chromosome band 17p (Gallego et al., 2010; Donehower et al., 2019). Other less frequent mechanism includes mutations of both TP53 alleles or mutation of one allele and retention of the second wild-type allele. A homozygous
TP53 deletion is a rare event, possibly due to its close relationship with genes essential for the cell (e.g., POLR2A) (Donehower et al., 2019). As a result, TP53 gene alterations are useful signals of many types of cancer in humans (Roa et al., 2002). Likewise, in a recent study using exome sequencing in twelve types of cancer, TP53 was the most frequently mutated gene in most cancer types studied (Duffy et al., 2017).

In this regard, analysis of important neoplasms of lung, breast, colon, stomach, and other organs indicates that TP53 mutations are the most common genetic abnormalities in human cancer. To date, multiple variants of TP53 have been analyzed to understand the molecular mechanisms of cancer initiation and progression. Studies have been conducted in various populations where cancer is recurrent and are initially based on SNPs selection (Hao et al., 2013).

The mutations reported for TP53 gene are collected in different databases. The main compendium is the International Agency for Research on Cancer (IARC), which includes three types of data: somatic mutations, germline mutations, and polymorphisms. Importantly, it has been reported that more than $50 \%$ of human neoplasms present somatic mutations in TP53, with a registry of approximately 21,512 somatic mutations and 283 germline mutations in all types of cancer (Oliver et al., 2002; Rangel et al., 2006). 
The role of somatic TP53 mutations in the steep rise in cancer rates with aging has not been investigated at a population level (Richarson, 2013). This relationship was quantified by using the International Agency for Research on Cancer (IARC) TP53 and GLOBOCAN cancer databases. TP53 mutations are associated with the aging-related rise in cancer incidence rates. However, preneoplastic TP53 mutations do not confer a growth advantage in gastric tumors and the evidence is less convincing than in other types of cancer (Morgan et al., 2003).

\section{TP53 variations databases: ClinVar}

The ClinVar database is a recent initiative of the NCBI (National Center for Biotechnology Information) for collecting information on variants with clinical relevance to support a molecular diagnosis by genotype-phenotype association from real patient data. ClinVar database provides a file of associations between variants of medical importance and phenotypes for multiple genes, including the TP53 tumor suppressor (Landrum et al., 2013).

In ClinVar, the interpretation of variation in sequences depends on a classification system standardized by two associations: The American College of Medical Genetics and Genomics and The Association for Molecular Pathology (ACMG). Currently, this system allows classification of a variant as pathogenic when the molecular consequences lead to a loss of function in that gene associated with a certain disease (Richards et al., 2015).

For the TP53 gene, 298 pathogenic mutations have been reported concerning hereditary cancer, predisposition to syndromes, Li-Fraumeni Syndrome, adenocarcinomas, and osteosarcomas (ClinVar database). Within the coding region of the gene, around $60 \%$ of pathogenic mutations are concentrated in the area between exons 5 and 8, affecting the DBD domain involved in DNA recognition and binding. TP 53 mutations within the domain affect its function, particularly when they occur within the so called hotspots that correspond to points necessary for protein function, such as DNA contact (codons 248 and 273) or stability (codons 175, 249, and 282) (Petitjean et al., 2007) (Table 1).

Approximately $5 \%$ of mutations reported in exon 4 are involved in the PRD domain necessary for complete suppressive activity of $\mathrm{P}_{53}$, which participates in the induction of apoptosis (Rangel et al., 2006). Among these, the clinical significance of mutation c.358 A>G for exon 4 remains uncertain and, therefore, there is a classification conflict as a pathogenic variant (Table 1).

Finally, around $6 \%$ of mutations are reported in exons 9 and 10 of the TD domain (Table 1 ), which is responsible for the oligomerization of P53 molecules. Variation in this domain can interfere with the formation of the dimer and tetramer.

Non-synonymous mutations can cause functional inactivation due to the generation of truncated monomers that are unable to establish the correct contacts, whereas synonymous mutations can affect the structure and dynamics of dimer stabilization during protein formation (Castaño et al., 1996). Therefore, these variants may be involved in the loss of $\mathrm{P}_{53}$ function in malignant cells (Rangel et al., 2006; López, 2011).

Mutations in non-coding regions have not been as widely studied as mutations in coding sequences despite the finding that many SNPs in the TP53 gene are in intronic regions (Marsh et al., 2001). Variants have been reported in intronic regions for TP53 as: variant c. 994-1G>A in intron 9, c.920-1G>A in intron 8, and c. 101-2A $>\mathrm{G}$ in intron 10 (Table 1). These mutations in non-coding regions can affect splicing sites, which lead to truncated protein products or reduced protein levels. The transition from A to G in intron 10, which eliminates a splicing acceptor site and causes a frameshift (change in reading frame), was recently reported in a pediatric adrenocortical tumor (Ming et al., 2012). It has been proposed that intronic variation influences susceptibility to cancer via regulation of gene expression, splicing, or mRNA stability, and these polymorphisms may be in linkage disequilibrium with other functional polymorphisms that could increase the risk of cancer (Sprague et al., 2007).

Most studies of TP53 have only examined exons $5-8$, in which missense mutations are most common, without considering that exons 2-4 and 9-11 also present many deletions and insertions. ClinVar has reported 135 pathogenic deletions in the TP53 gene. These deletions can cause disruptions in the reading frame during translation because the number of deleted nucleotides is not anmultiple of three (The sequence Ontology Browser), then the sequence of amino acids translated from the mutated gene changes from the point of the deletion (Castaño et al., 1996). Of note, in LiFraumeni syndrome, pathogenic deletions of $1 \mathrm{bp}$ have been reported in codons 178 and 317 (Table 1).

To date, 46 pathogenic duplications have been identified. Some duplications generate a change in the reading frame during translation (frameshift variant), resulting in an effect similar to that caused by deletions. Other duplications constitute an intronic mutation in the acceptor splicing site (splice acceptor variant). In this sense, a mutation in the splicing regulatory region can result in deleterious effects in the splicing process of mRNA precursors (Ward et al., 2010), consequently producing a different RNA and a non-functional protein. of note, in addition to the duplications, pathogenic insertions in ovarian neoplasms and hereditary cancer predisposition syndrome have been identified (Table 1).

Of the total of TP53 variants reported as pathogenic, approximately $35 \%$ are punctual (point mutations), with a single change of nucleotide base. Concerning the known molecular consequences, most of the identified point mutations result in a unique amino acid change 
that typically alters the binding of $\mathrm{P}_{53}$ to DNA. These missense mutations inactivate the gene protein product by not allowing its binding to DNA, making it incapable of activating its target genes (Rangel et al., 2006).

Additionally, a smaller percentage of TP 53 variants correspond to nonsense mutations, i.e., the substitution of one base for another that gives rise to a stop codon, causing premature termination of protein synthesis and, consequently, the formation of a protein truncated at the point of mutation. Studies have noted that the variation c.637C $>\mathrm{T}$ in codon 213 (Arg213Ter) is the most frequent nonsense mutation in various cancers, including colorectal ( $41 \%$ of all nonsense mutations), gastric (33\%), and breast cancer $(21 \%)$, because codon 213, which consists of a CpG dinucleotide, is the main methylation target and the nonsense mutation results in the endogenous deamination of 5-methylcytosine to thymine. It has been suggested that this dinucleotide, besides being an endogenous pro-mutagenic factor, could be a preferential target for exogenous carcinogenic chemicals (Shuyer et al., 1998).

In summary, the variants reported here demonstrate that access to knowledge and interpretation of variants of clinical importance are relevant to a better understanding of diseases. The current research focused on identification of biomarkers is intended to improve molecular knowledge about the specific cellular mechanisms that cause or drive tumor transformation within the enormous complexity of cancer. Important variations in the TP53 tumor suppression gene have been identified in humans and their patterns can show great differences not only between tumor types but also between different populations depending on genetic variability and environmental factors (Vaiva et al., 2009). Among these variants, those identified as pathogenic typically result in a single amino acid change that alters the binding of P53 to DNA, induce a change in the reading frame (frameshift), or cause premature interruption of translation leading to inactivation of the protein.

\section{P53 variations databases: Uniprot}

According to the Universal Protein Resource (UniProt) database, a total of 1363 variants have been reported for the TP53 gene. In UniProt, TP53 variants associated with a disease are described by the amino acid change, the abbreviation of the associated disease, the effect (s) of the variation on the protein, and the cell and/or organism if known (Table 2). It should be noted that polymorphisms associated with human diseases have been validated in the dbSNP NCBI database. However, polymorphisms of a single amino acid caused by a change of a single nucleotide are relatively rare and have very low frequencies to be reported in the dbSNP.
Variation in TP53 occurs in conditions like Barrett's metaplasia, in which the stratified squamous epithelium normally in the lower part of the esophagus is replaced by a metaplastic columnar epithelium. This condition develops as a complication in approximately $10 \%$ of patients with chronic gastroesophageal reflux disease and predisposes patients to the development of esophageal adenocarcinoma. In addition, TP53 variants have been reported in Li-Fraumeni Syndrome (LFS), a hereditary, autosomal dominant disorder that predisposes patients to cancer.

Four types of cancer represent $80 \%$ of tumors occurring in carriers of a TP53 germline mutation, namely breast cancer, bone and soft tissue sarcomas, brain tumors, and adrenocortical carcinomas. Less common tumors include papilloma and choroidal plexus carcinoma before age 15; rhabdomyosarcoma before age 5; and leukemia, Wilms' tumor, malignant phyllode tumor, colorectal cancer, and gastric cancer (Table 2).

Under normal conditions, P53 protein is expressed at low levels. However, the P53 pathway is activated by any stress that alters the progression of the normal cell cycle or induces mutations to the genome leading to the transformation of a normal cell into a cancer cell (Bourdon, 2007). Therefore, P53 is considered to play an important role in maintaining the integrity of the genome; hence, loss of P53 function would allow the survival of genetically damaged cellular elements, eventually leading to tumor cell transformation (Rangel et al., 2006).

Two general types of P53 mutations have been described: contact and conformational. The contact mutation proteins largely maintain the conformation of the wild-type folded protein, since the specific residues that are mutated are unable to bind to P53-specific DNA promoter sites. The conformational mutations (also known as structural mutations) cause protein destabilization, decrease its melting temperature, and decrease deployment at physiological temperatures. Mutations in P53 may result in the loss of its function as a tumor suppressor or an increase in oncogenic activity (Duffy et al., 2017).

Current evidence indicates that alterations of $\mathrm{P} 53$ at the gene level occur late in the pathogenesis of cancer and that the most frequent mechanism of inactivation corresponds to mutation of one allele followed by the deletion of the remaining allele (Gallego et al., 2010). As a result, TP53 gene alterations are useful signals of many types of cancer in humans (Roa et al., 2002). Likewise, in a recent study using exome sequencing in twelve types of cancer, P53 was the most frequently mutated gene in most cancer types studied (Duffy et al., 2017). 


\begin{tabular}{|c|c|c|c|c|c|c|c|}
\hline $\begin{array}{l}\text { P53 } \\
\text { DOMAIN }\end{array}$ & EXON & RSID & VARIATION & TYPE & $\begin{array}{l}\text { PROTEIN } \\
\text { CHANGE }\end{array}$ & $\begin{array}{l}\text { CLINICAL } \\
\text { SIGNIFICANCE }\end{array}$ & CONDITION \\
\hline \multirow{21}{*}{$\begin{array}{c}\text { DBD } \\
\text { DOMAIN }\end{array}$} & \multirow{21}{*}{$5-8$} & rs 11540652 & c. $743 \mathrm{G}>\mathrm{T}$ & SNV & p.Arg248Leu & Likely Pathogenic & $\begin{array}{l}\text { Hereditary cancer-predisposing syndrome, Uterine } \\
\text { Carcinosarcoma, Transitional cell carcinoma of the bladder, } \\
\text { Neoplasm of brain, Squamous cell lung carcinoma, } \\
\text { Brainstem glioma ...(19) }\end{array}$ \\
\hline & & rs 11540652 & c. $743 \mathrm{G}>\mathrm{C}$ & SNV & p.Arg248Pro & Likely Pathogenic & $\begin{array}{l}\text { Li-Fraumeni syndrome, Ovarian Serous } \\
\text { Cystadenocarcinoma, Multiple myeloma, Adenocarcinoma of } \\
\text { stomach, Uterine Carcinosarcoma...(21) }\end{array}$ \\
\hline & & rs11540652 & c. $743 \mathrm{G}>\mathrm{A}$ & SNV & p.Arg248Gln & $\begin{array}{l}\text { Pathogenic/Likely } \\
\text { Pathogenic }\end{array}$ & $\begin{array}{l}\text { Li-Fraumeni syndrome } 1 \text {, Hereditary cancer-predisposing } \\
\text { syndrome, Sarcoma, Acute myeloid leukemia, Neoplasm of } \\
\text { the breast...(32) }\end{array}$ \\
\hline & & rs 121912651 & c. $742 \mathrm{C}>\mathrm{G}$ & SNV & p.Arg248Gly & Likely Pathogenic & $\begin{array}{l}\text { Uterine Carcinosarcoma,Pancreatic adenocarcinoma, } \\
\text { Neoplasm of the breast, Neoplasm of the large intestine, } \\
\text { Squamous cell lung carcinoma...(22) }\end{array}$ \\
\hline & & rs121912651 & c. $742 \mathrm{C}>\mathrm{T}$ & SNV & p.Arg248Trp & Pathogenic & $\begin{array}{l}\text { Li-Fraumeni syndrome 1, Hereditary cancer-predisposing } \\
\text { syndrome, Acute myeloid leukemia, Lung adenocarcinoma, } \\
\text { Glioblastoma...(31) }\end{array}$ \\
\hline & & rs 1555525498 & $\begin{array}{l}\text { c. } 741 \_742 \\
\text { delinsTT }\end{array}$ & INDEL & p.Arg248Trp & Likely Pathogenic & Li-Fraumeni syndrome \\
\hline & & rs 28934576 & c. $818 \mathrm{G}>\mathrm{A}$ & SNV & p.Arg273His & $\begin{array}{l}\text { Pathogenic/Likely } \\
\text { Pathogenic }\end{array}$ & $\begin{array}{l}\text { Li-Fraumeni syndrome 1, Anaplastic thyroid carcinoma, } \\
\text { Hereditary cancer-predisposing syndrome, Squamous cell } \\
\text { lung carcinoma, Adenocarcinoma of stomach...(31) }\end{array}$ \\
\hline & & rs 28934576 & c. $818 \mathrm{G}>\mathrm{C}$ & SNV & p.Arg273Pro & $\begin{array}{l}\text { Pathogenic/Likely } \\
\text { Pathogenic }\end{array}$ & $\begin{array}{l}\text { Hereditary cancer-predisposing syndrome, Multiple } \\
\text { myeloma, Adrenocortical carcinoma, Pancreatic } \\
\text { adenocarcinoma, Malignant melanoma of skin...(22) }\end{array}$ \\
\hline & & rs 28934576 & c. $818 \mathrm{G}>\mathrm{T}$ & SNV & p.Arg273Leu & Pathogenic & $\begin{array}{l}\text { Pancreatic adenocarcinoma, Neoplasm of brain, Squamous } \\
\text { cell carcinoma of the head and neck, Chronic lymphocytic } \\
\text { leukemia, Neoplasm of the large intestine...(22) }\end{array}$ \\
\hline & & rs121913343 & c. $817 \mathrm{C}>\mathrm{A}$ & SNV & p.Arg273Ser & $\begin{array}{l}\text { Pathogenic/Likely } \\
\text { Pathogenic }\end{array}$ & $\begin{array}{l}\text { Lung adenocarcinoma, Glioblastoma, Ovarian Serous } \\
\text { Cystadenocarcinoma, Chronic lymphocytic leukemia, } \\
\text { Malignant neoplasm of body of uterus...(21) }\end{array}$ \\
\hline & & rs 121913343 & c. $817 \mathrm{C}>\mathrm{G}$ & SNV & p.Arg273Gly & Pathogenic & Ovarian Neoplasms, Li-Fraumeni syndrome \\
\hline & & rs 28934578 & c. $524 \mathrm{G}>\mathrm{T}$ & SNV & p.Arg175Leu & $\begin{array}{l}\text { Conflicting } \\
\text { Interpretations of } \\
\text { Pathogenicity }\end{array}$ & $\begin{array}{l}\text { Hereditary cancer-predisposing syndrome, Li-Fraumeni } \\
\text { syndrome }\end{array}$ \\
\hline & & rs 28934578 & c. $524 \mathrm{G}>\mathrm{A}$ & SNV & p.Arg $175 \mathrm{His}$ & Pathogenic & $\begin{array}{l}\text { Li-Fraumeni syndrome } 1 \text {, Hereditary cancer-predisposing } \\
\text { syndrome, Malignant tumor of esophagus, Neoplasm, } \\
\text { Neoplasm of the breast...(10) }\end{array}$ \\
\hline & & rs 138729528 & c. $523 \mathrm{C}>\mathrm{T}$ & SNV & p.Arg175Cys & $\begin{array}{l}\text { Conflicting } \\
\text { Interpretations of } \\
\text { Pathogenicity }\end{array}$ & $\begin{array}{l}\text { Pancreatic adenocarcinoma, Malignant melanoma of } \\
\text { skin, Lung adenocarcinoma,Adenocarcinoma of stomach, } \\
\text { Medulloblastoma...(20) }\end{array}$ \\
\hline & & rs138729528 & c. $523 \mathrm{C}>\mathrm{G}$ & SNV & p.Arg 175Gly & $\begin{array}{l}\text { Pathogenic/Likely } \\
\text { Pathogenic }\end{array}$ & $\begin{array}{l}\text { Neoplasm of the large intestine, Malignant neoplasm of } \\
\text { body of uterus, Transitional cell carcinoma of the bladder, } \\
\text { Brainstem glioma, Hepatocellular carcinoma...(20) }\end{array}$ \\
\hline & & rs786202525 & c. $532 \mathrm{del}$ & DEL & p.His178fs & Pathogenic & $\begin{array}{l}\text { Li-Fraumeni syndrome 1, Hereditary cancer-predisposing } \\
\text { syndrome, Ovarian Neoplasms }\end{array}$ \\
\hline & & rs786202514 & c.511_515dup & DUP & p.Val173fs & Pathogenic & Hereditary cancer-predisposing syndrome \\
\hline & & rs 730882018 & c.216dup & DUP & p.Val73fs & Pathogenic & $\begin{array}{l}\text { Li-Fraumeni-like syndrome, Hereditary cancer-predisposing } \\
\text { syndrome, Li-Fraumeni syndrome }\end{array}$ \\
\hline & & rs587782609 & c.155_157dup & DUP & p.Trp53Ter & Pathogenic & Hereditary cancer-predisposing syndrome \\
\hline & & rs 1567546889 & & INS & p.Ser303fs & Pathogenic & Ovarian Neoplasms \\
\hline & & rs 1555525226 & c. $842 \_843$ insG & INS & p.Asp281fs & Pathogenic & Hereditary cancer-predisposing syndrome \\
\hline \multirow{12}{*}{$\begin{array}{l}\text { PRD } \\
\text { DOMAIN }\end{array}$} & \multirow{12}{*}{4} & rs 1057520003 & c. $373 \mathrm{~A}>\mathrm{C}$ & SNV & p.Thr125Pro & Likely Pathogenic & $\begin{array}{l}\text { Neoplasm of the large intestine, Squamous cell carcinoma of } \\
\text { the head and neck, Transitional cell carcinoma of the bladder, } \\
\text { Malignant melanoma of skin, Neoplasm of the breast...(16) }\end{array}$ \\
\hline & & rs 1567555667 & c. $338 \mathrm{~T}>\mathrm{G}$ & SNV & p.Phe113Cys & Likely Pathogenic & Ovarian Neoplasms \\
\hline & & rs 1057519997 & c. $332 \mathrm{~T}>\mathrm{G}$ & SNV & p.Leu111Arg & Likely Pathogenic & $\begin{array}{l}\text { Adenocarcinoma of stomach, Chronic lymphocytic leukemia, } \\
\text { Squamous cell lung carcinoma, Hepatocellular carcinoma... } \\
\text { (4) }\end{array}$ \\
\hline & & rs1057519997 & c. $332 \mathrm{~T}>\mathrm{A}$ & SNV & p.Leu111Gln & Likely Pathogenic & $\begin{array}{l}\text { Squamous cell lung carcinoma, Adenocarcinoma of stomach, } \\
\text { Malignant melanoma of skin, Hepatocellular carcinoma, } \\
\text { Neoplasm of the breast...(3) }\end{array}$ \\
\hline & & $?$ & & INDEL & p.Arg110Pro & Pathogenic & Li-Fraumeni syndrome \\
\hline & & rs 11540654 & c. $329 \mathrm{G}>\mathrm{C}$ & SNV & p.Arg110Pro & $\begin{array}{l}\text { Pathogenic/Likely } \\
\text { Pathogenic }\end{array}$ & $\begin{array}{l}\text { Hereditary cancer-predisposing syndrome, Li-Fraumeni } \\
\text { syndrome }\end{array}$ \\
\hline & & rs 11540654 & c. $329 \mathrm{G}>\mathrm{T}$ & SNV & p.Arg110Leu & $\begin{array}{l}\text { Pathogenic/Likely } \\
\text { Pathogenic }\end{array}$ & $\begin{array}{l}\text { Li-Fraumeni syndrome, Hereditary cancer-predisposing } \\
\text { syndrome, Ovarian Neoplasms }\end{array}$ \\
\hline & & rs 1064796722 & c. $326 \mathrm{~T}>\mathrm{G}$ & SNV & p.Phe109Cys & Likely Pathogenic & Ovarian Neoplasms \\
\hline & & rs 1057523496 & c. $325 \mathrm{~T}>\mathrm{G}$ & SNV & p.Phe109Val & Likely Pathogenic & not provided \\
\hline & & rs587781504 & c. $314 \mathrm{G}>\mathrm{T}$ & SNV & p.Gly105Val & Likely Pathogenic & Ovarian Neoplasms \\
\hline & & rs 1060501195 & c. $313 \mathrm{G}>\mathrm{A}$ & SNV & p.Gly105Ser & Likely Pathogenic & Hereditary cancer-predisposing syndrome \\
\hline & & rs121912661 & c. $105 \mathrm{G}>\mathrm{T}$ & SNV & p.Leu35Phe & Pathogenic & Carcinoma of pancreas \\
\hline
\end{tabular}




\begin{tabular}{|c|c|c|c|c|c|c|c|}
\hline $\begin{array}{c}\text { P53 } \\
\text { DOMAIN }\end{array}$ & EXON & RSID & VARIATION & TYPE & $\begin{array}{l}\text { PROTEIN } \\
\text { CHANGE }\end{array}$ & $\begin{array}{l}\text { CLINICAL } \\
\text { SIGNIFICANCE }\end{array}$ & CONDITION \\
\hline \multirow{8}{*}{$\begin{array}{c}\text { TD } \\
\text { DOMAIN }\end{array}$} & \multirow{8}{*}{$9-10$} & rs876659384 & c. $976 \mathrm{G}>\mathrm{T}$ & SNV & p.Glu326Ter & Pathogenic & $\begin{array}{l}\text { Hereditary cancer-predisposing syndrome, Li-Fraumeni } \\
\text { syndrome, Ovarian Neoplasms }\end{array}$ \\
\hline & & rs 863224500 & c. $973 \mathrm{G}>\mathrm{T}$ & SNV & p.Gly325Ter & Pathogenic & Li-Fraumeni syndrome \\
\hline & & rs764735889 & c. $949 \mathrm{C}>\mathrm{T}$ & SNV & p.Gln317Ter & $\begin{array}{l}\text { Pathogenic/Likely } \\
\text { Pathogenic }\end{array}$ & $\begin{array}{l}\text { Hereditary cancer-predisposing syndrome, Li-Fraumeni } \\
\text { syndrome }\end{array}$ \\
\hline & & $\begin{array}{l}\text { rs758194998 } \\
\text { rs1567545268 }\end{array}$ & $\begin{array}{l}\text { c. } 1034 \mathrm{C}>\mathrm{T} \\
\text { c. } 1028 \mathrm{~T}>\mathrm{A}\end{array}$ & $\begin{array}{l}\text { SNV } \\
\text { SNV }\end{array}$ & $\begin{array}{l}\text { p.Ser345Leu } \\
\text { p.Ile343Lys }\end{array}$ & $\begin{array}{l}\text { Conflicting } \\
\text { Interpretations of } \\
\text { Pathogenicity } \\
\text { Uncertain Significance }\end{array}$ & $\begin{array}{l}\text { Hereditary cancer-predisposing syndrome } \\
\text { Li-Fraumeni syndrome }\end{array}$ \\
\hline & & rs554738122 & c. $1009 \mathrm{C}>\mathrm{T}$ & SNV & p.Arg337Ter & $\begin{array}{l}\text { Conflicting } \\
\text { Interpretations of } \\
\text { Pathogenicity }\end{array}$ & $\begin{array}{l}\text { Hereditary cancer-predisposing syndrome, Li-Fraumeni } \\
\text { syndrome } 1\end{array}$ \\
\hline & & rs730882019 & c.455dup & DUP & p.Pro153fs & Pathogenic & $\begin{array}{l}\text { Li-Fraumeni syndrome } 1 \text {, Hereditary cancer-predisposing } \\
\text { syndrome }\end{array}$ \\
\hline & & rs 1567546196 & c.949del & DEL & p.Gln317fs & Pathogenic & Li-Fraumeni syndrome, Ovarian Neoplasms \\
\hline & & rs 1567542146 & c.1014_1015insT & INS & p.Glu339Ter & Pathogenic & Ovarian Neoplasms \\
\hline \multirow{11}{*}{$\begin{array}{l}\text { INTRONIC } \\
\text { REGION }\end{array}$} & & rs 11575997 & & SNV & & Pathogenic & Li-Fraumeni syndrome \\
\hline & & rs 11575997 & c. $993+1 \mathrm{G}>\mathrm{A}$ & SNV & $\begin{array}{l}\text { Splice Donor } \\
\text { Variant }\end{array}$ & Pathogenic & Li-Fraumeni syndrome, Ovarian Neoplasms \\
\hline & & rs1131691033 & $?$ & & $\begin{array}{l}\text { Splice Donor } \\
\text { Variant }\end{array}$ & Pathogenic & Hereditary cancer-predisposing syndrome \\
\hline & & rs587781702 & c. $920-1 \mathrm{G}>\mathrm{A}$ & SNV & $\begin{array}{l}\text { Splice Donor } \\
\text { Variant }\end{array}$ & Pathogenic & $\begin{array}{l}\text { Hereditary cancer-predisposing syndrome, not provided, } \\
\text { Ovarian Neoplasms }\end{array}$ \\
\hline & & rs587781702 & c. $920-1 \mathrm{G}>\mathrm{T}$ & SNV & $\begin{array}{l}\text { Splice Donor } \\
\text { Variant }\end{array}$ & Pathogenic & $\begin{array}{l}\text { Hereditary cancer-predisposing syndrome, Ovarian } \\
\text { Neoplasms }\end{array}$ \\
\hline & & rs 1555525040 & c.917_919+10del & DEL & $\begin{array}{l}\text { Splice Donor } \\
\text { Variant }\end{array}$ & Pathogenic & Li-Fraumeni syndrome \\
\hline & & rs 1131691016 & c. $919+2 \mathrm{~T}>\mathrm{A}$ & SNV & $\begin{array}{l}\text { Splice Donor } \\
\text { Variant }\end{array}$ & Pathogenic & Hereditary breast and ovarian cancer syndrome \\
\hline & & rs1131691039 & c. $919+1 \mathrm{G}>\mathrm{A}$ & SNV & $\begin{array}{l}\text { Splice Donor } \\
\text { Variant }\end{array}$ & Pathogenic & Li-Fraumeni syndrome 1 \\
\hline & & rs 878854073 & c. $673-1 \mathrm{G}>\mathrm{T}$ & SNV & $\begin{array}{l}\text { Splice Donor } \\
\text { Variant }\end{array}$ & Pathogenic & Li-Fraumeni syndrome \\
\hline & & rs878854073 & c. $673-1 \mathrm{G}>\mathrm{A}$ & SNV & $\begin{array}{l}\text { Splice Donor } \\
\text { Variant }\end{array}$ & Pathogenic & Hereditary cancer-predisposing syndrome \\
\hline & & rs 1555525585 & c. $673-2 A>G$ & SNV & $\begin{array}{l}\text { Splice Donor } \\
\text { Variant }\end{array}$ & Pathogenic & Li-Fraumeni syndrome,Ovarian Neoplasms \\
\hline
\end{tabular}


$110-110 \quad \mathrm{R} \rightarrow \mathrm{L}$

133-133 $\quad \mathrm{M} \rightarrow \mathrm{T}$

151-151 $\quad \mathrm{P} \rightarrow \mathrm{S}$

$152-152 \quad \mathrm{P} \rightarrow \mathrm{L}$

163-163 Y $\rightarrow \mathrm{C}$

175-175 $\mathrm{R} \rightarrow \mathrm{H}$

193-193 $\quad \mathrm{H} \rightarrow \mathrm{R}$

213-213 R $\rightarrow P$

220-220 Y $\rightarrow \mathrm{C}$

241-241 $\quad \mathrm{S} \rightarrow \mathrm{F}$

245-245 $\quad \mathrm{G} \rightarrow \mathrm{C}$

$245-245 \quad \mathrm{G} \rightarrow \mathrm{D}$

245-245 $\quad \mathrm{G} \rightarrow \mathrm{S}$

245-245 $\quad \mathrm{G} \rightarrow \mathrm{V}$

248-248 $\quad \mathrm{R} \rightarrow \mathrm{Q}$

248-248 $\mathrm{R} \rightarrow \mathrm{W}$

252-252 $\mathrm{L} \rightarrow \mathrm{P}$

258-258 $\quad \mathrm{E} \rightarrow \mathrm{K}$
In family cancer not coincident with

LFS; Germinal mutation and in sporadic cancer; somatic mutation; does not induce SNAI1 degradation.

In LFS; Germinal mutation and in sporadic cancer; somatic mutation. Corresponds to variant rs28934873.

In LFS; Germinal mutation and in sporadic cancer; somatic mutation. Corresponds to variant rs28934874.

In LFS; Germinal mutation and in sporadic cancer; somatic mutation.

In LFS; Germinal mutation and in sporadic cancer; somatic mutation.

In LFS; Germinal mutation and in sporadic cancer; somatic mutation; does not induce SNAI1 degradation; reduces interaction with ZNF385A. Corresponds to variant rs28934578

In LFS; Germinal mutation and in sporadic cancer; somatic mutation.

In LFS; Germinal mutation and in sporadic cancer; somatic mutation.

In LFS; Germinal mutation and in sporadic cancer; somatic mutation.

In LFS; Germinal mutation and in sporadic cancer; somatic mutation. Corresponds to variant rs28934573.

In LFS; Germinal mutation and in sporadic cancer; somatic mutation.

In LFS; Germinal mutation and in sporadic cancer; somatic mutation.

In LFS; Germinal mutation and in sporadic cancer; somatic mutation. Corresponds to variant rs28934575

In LFS; Germinal mutation and in sporadic cancer; somatic mutation.

In LFS; Germinal mutation and in sporadic cancer; somatic mutation. Corresponds to variant rs 11540652

In LFS; Germinal mutation and in sporadic cancer; somatic mutation.

In LFS; Germinal mutation and in sporadic cancer; somatic mutation.

In LFS; Germinal mutation and in sporadic cancer; somatic mutation.
VAR_005861 Lim et al., 2010

VAR 005875 Law et al., 1991

VAR 005895 Caamano et al., 1993

VAR 005897 Casson et al., 1991

VAR 033035 Sjoeblom et al., 2006;

Chanock et al., 2007

VAR_005932 Lim et al., 2010; Casson et al., 1991;

Sjoeblom et al., 2006; Das et al., 2007;

Frebourg et al., 1995; Varley et al., 1995

VAR_005948 Sjoeblom et al., 2006;

Frebourg et al., 1995

VAR_036506 Sjoeblom et al., 2006

VAR_005957 Caamano et al., 1993;

Van Rensburg et al., 1998

VAR 005969 Sjoeblom et al., 2006;

Rodrigues et al., 1990

VAR_005972 Srivastava et al., 1990;

Audrezet et al., 1996

VAR_005973 Srivastava et al., 1990;

Audrezet et al., 1996

VAR_005974 Audrezet et al., 1996

VAR_005975 Hollstein et al., 1990

VAR_005983 Caamano et al., 1993; Sjoeblom et al., 2006; Frebourg et al., 1995;

Hollstein et al., 1990

VAR_005984 Sjoeblom et al., 2006; Malkin et al., 1990; Audrezet et al., 1996

VAR 005988 Malkin et al., 1990

VAR $005991 \quad$ Malkin et al., 1990 


$\begin{array}{ll}\text { 272-272 } & \mathrm{V} \rightarrow \mathrm{L} \\ \text { 273-273 } & \mathrm{R} \rightarrow \mathrm{C} \\ \text { 273-273 } & \mathrm{R} \rightarrow \mathrm{H} \\ & \\ & \\ 273-273 & \mathrm{R} \rightarrow \mathrm{L} \\ \text { 275-275 } & \mathrm{C} \rightarrow \mathrm{Y} \\ & \\ 278-278 & \mathrm{P} \rightarrow \mathrm{L} \\ & \\ 278-278 & \mathrm{P} \rightarrow \mathrm{S}\end{array}$

$280-280 \quad \mathrm{R} \rightarrow \mathrm{K}$

282-282 $\quad \mathrm{R} \rightarrow \mathrm{Q}$

282-282 $\mathrm{R} \rightarrow \mathrm{W}$

292-292 K $\rightarrow$

309-309 $\quad \mathrm{P} \rightarrow \mathrm{S}$

325-325 $\mathrm{G} \rightarrow \mathrm{V}$

337-337 $\mathrm{R} \rightarrow \mathrm{C}$

337-337 $\mathrm{R} \rightarrow \mathrm{H}$

366-366 $\mathrm{S} \rightarrow \mathrm{A}$
In LFS; Germinal mutation and in sporadic cancer; somatic mutation.

In LFS; Germinal mutation and in sporadic cancer; somatic mutation.

In LFS; Germinal mutation and in sporadic cancer; somatic mutation; suppresses sequence-specific DNA binding; does not induce SNAI1 degradation. Corresponds to the variant rs28934576.

In LFS; Germinal mutation and in sporadic cancer; somatic mutation.

In LFS; Germinal mutation and in sporadic cancer; somatic mutation.

In LFS; Germinal mutation and in sporadic cancer; somatic mutation.

In LFS; Germinal mutation and in sporadic cancer; somatic mutation.

In family cancer not coincident with LFS; Germinal mutation and in sporadic cancer; somatic mutation; has no effect on the interaction with CCAR2

In family cancer not coincident with LFS; Germinal mutation and in sporadic cancer; somatic mutation.

In LFS; Germinal mutation and in sporadic cancer; somatic mutation; does not induce SNAI1 degradation. Corresponds to variant rs28934574.

In LFS; Germinal mutation and in sporadic cancer; somatic mutation.

In LFS; Germinal mutation and in sporadic cancer; somatic mutation.

In LFS; Germinal mutation. Corresponds to variant rs28934271.

In LFS; Germinal mutation and in sporadic cancer; somatic mutation.

In LFS; Germinal mutation and in sporadic cancer; somatic mutation.

In family cancer not coincident with LFS; Germinal mutation and in sporadic cancer; somatic mutation. Corresponds to variant rs 17881470.
VAR 005992

Felix et al., 1992

VAR_005993 Sjoeblom et al., 2006; Chanock et al., 2007; Frebourg et al., 1995;

Van Rensburg et al., 1998

VAR_005995 Lim et al., 2010; Caamano et al., 1993; Casson et al., 1991; Sjoeblom et al., 2006; Rodrigues et al., 1990; Malkin et al., 1992; Somers et al., 1992; Azuma et al., 2002; Chehab et al., 1999

VAR_036509

Sjoeblom et al., 2006

VAR 005998

Frebourg et al., 1995

VAR_006003

Hollstein et al., 1990

VAR_006004

Sjoeblom et al., 2006;

Van Rensburg et al., 1998;

Hollstein et al., 1990

VAR_006007

Bartek et al., 1990;

Qin et al., 2015

VAR 045387

Nimri et al., 2003;

Tu et al., 2008

VAR 006016 Lim et al., 2010;

Audrezet et al., 1996

VAR_015819 Gueran et al., 1999

VAR_006038 Azuma et al., 2002

VAR_006039 Malkin et al., 1992

VAR_006041 Ribeiro et al., 2001

VAR 035016 Ribeiro et al., 2001

VAR 022317 Ribeiro et al., 2001 


\section{PERSPECTIVES IN TREATMENT}

Currently, with the rise of next-generation sequencing and high throughput proteomics mass spectrometry, the study of different types of cancer has allowed the characterization of a series of mutations as potential drivers in the development of this pathology. Among the mutated genes in cancer, TP 53 hosts variants that occur with a high frequency.

From a therapeutic perspective, the goal is looking for the mutant $\mathrm{P}_{53}$ protein to be the target of treatments. However, the fact that mutants are diverse in form and function means that therapies must be directed with a large number of molecules that are selective to the various mutants of $\mathrm{P} 53$ and in turn do not affect the functioning of the wild form, a fact that has made difficult the application or successful outcome of treatments. In this sense, recently small interference RNAs (siRNAs) have been developed for many targets that can silence the expression of the mutated protein satisfactorily and that are also selective for a single nucleotide, so that they can be applied to multiple P53 mutants. Recently, Ubby et al. (2019), generated specific siRNAs for four of the six mutational hotspot of $\mathrm{P} 53$, which were able to silence only the mutant alleles without having an impact on the expression of the wild protein, representing an important advance in the treatment of around $10 \%$ of all types of cancer and highlighting the importance of the identification of variants in this gene. Recently in vitro hPSC stem cells line engineering with stable integration of CRISPR/Cas9 (Ihry et al., 2018) found that the lethal response to that double-strand breaks was $\mathrm{P}_{53} / \mathrm{TP} 53$ dependent, such that the efficiency of precise genome engineering in hPSCs with a wild-type $\mathrm{P}_{53}$ gene was severely reduced. The results of Ihry et al. (2018) indicate that Cas9 toxicity creates an obstacle to the highthroughput use of CRISPR/Cas9 for genome engineering and screening in these stem cells. The new small interference RNAs (siRNAs) and CRISPR/Cas9 therapy tools scenario is still a challenge, and new discoveries are expected for the development of this urgent therapy.

\section{REFERENCES}

Adrain C., Creagh E. (2001) Apoptosis-associated release of Smac/DIABLO from mitochondria requires active caspases and is blocked by Bcl-2. ЕMBO J. 20 (23): 6627-6636.

Alpízar W., Sierra R., Cuenca P., Une C., Mena F., Pérez G. (2005) Asociación del polimorfismo del codón 72 del gen p53 con el riesgo de cáncer gástrico en una población de alto riesgo de Costa Rica. Rev. Biol. Trop. $53(3-4): 317-324$.

Audrezet M.P., Robaszkiewicz M., Mercier B., Nousbaum J.B., Hardy E., Bail J.P. (1996) Molecular analysis of the TP53 gene in Barrett's adenocarcinoma. Hum. Mutat. 7: 109-113.
Azuma K., Shichijo S., Itoh K. (2002) Identification of a tumor-rejection antigen recognized by HLA-B46 restricted CTL. Submitted (MAR2002) to the EMBL/GenBank/DDBJ databases.

Bai L. and Zhu W. (2006) p53: Structure, Function and therapeutic applications. J. Cancer Mol. 2 (4): 141-153.

Ballesteros D., González P., Riascos M., Zambrano H. (2007) Protein p53: Signaling Pathways and Role in Carcinogenesis: a Review Rev. Cir. Traumatol. Buco-Maxilo-Fac. 7 (2): 37-54.

Bartek J., Iggo R., Gannon J., Lane D.P. (1990) Genetic and immunochemical analysis of mutant p53 in human breast cancer cell lines. Oncogene 5: 893-899.

Bhardwaj J.M., Wei J., Andl C., El-Rifai W., Peek R.M., Zaika A.I. (2015) Helicobacter pylori bacteria alter the p53 stress response via ErkHDM2 pathway. Oncotarget 6 (3): 1531.

Bouaoun L., Sonkin D., Ardin M., Hollstein M., Byrnes G. (2016) TP53 Variations in Human Cancers: New Lessons from the IARC TP53 Database and Genomics Data. Human Mutation 37 (9): 865-876.

Bourdon J.C. (2007) p53 and its isoforms in cancer. Br. J. Cancer 97: 277282.

Caamano J., Zhang S.Y., Rosvold E.A., Bauer B., Klein-Szanto A.J. (1993) p53 alterations in human squamous cell carcinomas and carcinoma cell lines. Am. J. Pathol. 142: 1131-1139.

Casson A.G., Mukhopadhyay T., Cleary K.R., Ro J.Y., Levin B., Roth J.A. (1991) p53 gene mutations in Barrett's epithelium and esophageal cancer. Cancer Res. 51: 4495-4499.

Castaño L., Bilbao J.R., Urrutia I. (1996) Introducción a la biología molecular y aplicación a la pediatría (2): Purificación de ácidos nucleicos. An. Esp. Pediatr. 45: 541-546.

Chanock S.J., Burdett L., Yeager M., Llaca V., Langeroed A., Presswalla S. (2007) Somatic sequence alterations in twenty-one genes selected by expression profile analysis of breast carcinomas. Breast Cancer Res. 9: R5 (doi:10.1186/bcr1637).

Chehab N.H., Malikzay A., Stavridi E.S., Halazonetis T.D. (1999) Phosphorylation of Ser-20 mediates stabilization of human p53 in response to DNA damage. Proc. Natl. Acad. Sci. USA 96: 13777-13782.

ClinVar. URL: http://www.ncbi.nlm.nih.gov/clinvar/ [26-06-2016]

Das S., Raj L., Zhao B., Kimura Y., Bernstein A., Aaronson S.A., Lee S.W. (2007) Hzf Determines cell survival upon genotoxic stress by modulating p 53 transactivation. Cell 130: 624-637.

Donehower L., Soussi T., Korkut A., Weinstein J., Akbani R., Wheeler D. ( 2019) Integrated Analysis of TP53 Gene and Pathway Alterations in The Cancer Genome Atlas. Cell Reports 28: 1370-1384.

Duffy M., Synnott N.C., Crown J. (2017) Mutant p53 as a target for cancer treatment. Eur. J. Cancer 83: 258-265.

Felix C.A., Nau M.M., Takahashi T., Mitsudomi T., Chiba I., Poplack D.G. (1992) Hereditary and acquired p53 gene mutations in childhood acute lymphoblastic leukemia. J. Clin. Invest. 89: 640-647.

Frebourg T., Barbier N., Yan Y., Garber J.E., Dreyfus M., Fraumeni J.F. (1995) Germ-line p53 mutations in 15 families with Li-Fraumeni syndrome. Am. J. Hum. Genet. 56: 608-615.

Funahashi A., Tanimura N., Morohashi M., Kitano H. (2003) Cell Designer: a process diagram editor for gene-regulatory and biochemical networks. BIOSILICO 1: 159-162. 
Gallego R., Pinazo M.D., \& Serrano M. (2010) El ciclo celular y el gen p53: Aproximación a la oftalmología molecular. Arch. Soc. Esp. Oftalmol. 85 (7): 229-231.

Gnanapradeepan K., Basu S., Barnoud T., Budina-Kolomets A., Kung C., Murphy M.E. (2018) The p53 Tumor Suppressor in the Control of Metabolism and Ferroptosis. Front. Endocrinol. 9: 124.

GLOBOCAN (Globo Cancer Obsevatory) https:// gco.iarc.fr/[12-06-2017]

Gueran S., Tunca Y., Imirzalioglu N. (1999) Hereditary TP53 codon 292 and somatic P16INK4A codon 94 mutations in a LiFraumeni syndrome family. Cancer Genet. Cytogenet. 113: 145-151.

Hao X.D., Yang Y., Song X., Zhao X.K., Wang L.D., He J.D. (2013) Correlation of telomere lenght shortening with TP53 somatic mutations, polymorphisms and allelic loss in breast tumors and esophageal cáncer. Oncol. Rep. 29 (1): $226-236$

Harris C.C. (1996) Structure and function of the p53 tumor supresor gene: clues for rational cáncer therapeutic strategies. J. Natl. Cancer Ins. 88 (20): 1442-1445.

Herrera J.C., Isaza L.F., Ramírez J.L., Vásquez G., Muñeton C.M. (2010) Detección de aneuploidías del cromosoma 17 y deleción del gen TP53 en una amplia variedad de tumores sólidos mediante hibridación in situ fluorescente bicolor. Biomédica 30 (3): 390400.

Hollstein M.C., Metcalf R.A., Welsh J.A., Montesano R., Harris C.C. (1990) Frequent mutation of the p53 gene in human esophageal cancer. Proc. Natl. Acad. Sci. USA 87: 9958-9961.

IARC TP53 Database (2016) URL: http://p53.iarc. $\mathrm{fr} /[12-06-2017]$

Ihry R.J., Worringer K.A., Salick M.R., Frias E., Ho D., Theriault K., Kommineni S., Chen J., Sondey M., Ye C., Randhawa R., Kulkarni T., Yang Z., McAllister G., Russ C., Reece-Hoyes J., Forrester W., Hoffman G.R., Dolmetsch R., Kaykas A., Randhawa R. (2018) p53 inhibits CRISPR-Cas9 engineering in human pluripotent stem cells. Nature Medicine 24 (7): 939.

Isobe M., Emanuel B.S., Givol D., Oren M., Croce C.M. (1986) Localization of gene for human p53 tumour antigen to band 17p13. Nature 320 (6057): 84-5.

Joerger A.C., Allen M.D., Fersht A.R. (2004) Crystal structure of a superstable mutant of human p53 core domain. Insights Structure and function of $\mathrm{p} 53$ cancer mutants into the mechanism of rescuing oncogenic mutations. J. Biol. Chem. 279: 1291-1296.
Joerger A.C. (2008) Structural biology of the tumor suppressor p53. Annu. Rev. Biochem. 77: 557-582.

Kastenhuber E., Lowe S. (2017) Putting p53 in Context. Cell 170: 1062-1078.

Kern S.E., Kinzler K.W., Bruskin A., Jarosz D., Friedman P., Prives C., Vogelstein B. (1991) Identification of $\mathrm{p} 53$ as a sequence-specific DNA-binding protein. Science 252 (5013): 1708-11.

Kitayner M., Rozenberg H., Kessler N., Rabinovich D., Shaulov L., Haran T.E. (2006) Structural basis of DNA recognition by $\mathrm{p} 53$ tetramers. Mol. Cell. 22 (6): 741-753.

Landrum M.J., Lee J.M., Riley G.R., Jang W., Rubinstein W.S., Church D.M. (2013) ClinVar: public archive of relationships among sequence variation and human phenotype. Nucleic Acids Res. 42 (Database): 1-6.

Law J.C., Strong L.C., Chidambaram A., Ferrell R.E. (1991) A germ line mutation in exon 5 of the p53 gene in an extended cancer family. Cancer Res. 51: 6385-6387.

Lee J.H., Kang V., Jin Z.Y., Kang M.Y., Yoon Y., Hyun J.W. (2010) The p53-inducible gene 3 (PIG3) contributes to early cellular response to DNA damage. Oncogene 29 (10): 1431-1450.

Lim S.O., Kim H., Jung G. (2010) p53 inhibits tumor cell invasion via the degradation of snail protein in hepatocellular carcinoma. FEBS Lett. 584: 2231-2236.

López I. (2011) Identificación y análisis del efecto de mutaciones en TP53 asociadas a la patología tumoral. Tesis de Maestría en Ciencias Biológicas. Universidad de la República, Montevideo, Uruguay.

Malkin D., Li F.P., Strong L.C., Fraumeni J.F., Nelson C.E., Kim D.H., Kassel J. (1990) Germ line p53 mutations in a familial syndrome of breast cancer, sarcomas, and other neoplasms. Science 250: 1233-1238.

Malkin D., Jolly K.W., Barbier N., Look A.T., Friend S.H., Gebhardt M.C. et al. (1992) Germline mutations of the p53 tumorsuppressor gene in children and young adults with second malignant neoplasms. N. Engl. J. Med. 326:1309-1315.

Marsh A., Spurdle A., Turner B., Fereday S., Thorne H., Pupo G. (2001) The intronic G13964C variant in p53 is not a highrisk mutation in familial breast cancer in Australia. Breast Cancer Res. 3 (5): 346-349.

McBride O.W., Merry D., Givol D. (1986) The gene for human p53 cellular tumor antigen is located on chromosome 17 short arm (17p13). Proc. Natl. Acad. Sci. USA 83 (1): 130-134.
Ming F., Simeonova I., Toledo F. (2012) p53: Point Mutations, SNPs and Cancer, Point Mutation. In: Logie C. (Ed.) Biochemistry, Genetics and Molecular Biology "Point Mutation". InTech, Rijeka, pp. 301-322.

Morgan C., Jenkins G.J.S., Ashton T., Griffiths A.P., Baxter J.N., Parry E.M., Parry J.M. (2003) Detection of p 53 mutations in precancerous gastric tissue. British Journal of Cancer 89 (7): 1314 .

Nimri L.F., Owais W., Momani E. RT. (2003) "Detection of P53 gene mutations and serum p53 antibodies associated with cigarette smoking." Submitted (AUG-2003) to the EMBL/GenBank/DDBJ databases.

Olivier M., Eeles R., Hollstein M., Khan M.A., Harris C.C., Hainaut P. (2002) The IARC TP53 Database: Nex Online Mutation Analysis and Recommendations to Users. Hum. Mutat. 19 (6): 607-614.

Petitjean A., Mathe E., Kato S., Ishioka C., Taytigian S.V., Ahinaut P., Olivier M. (2007) Impact of mutant p53 functional properties on TP53 mutation patterns and tumor phenotype: Lessons from recents developments in the IARC TP53 Database. Hum. Mutat. 28 (6): 622-629.

Pettersen E.F., Goddard T.D., Huang C.C., Couch G.S., Greenblatt D.M., Meng E.C., Ferrin T.E. (2004) UCSF Chimera: a visualization system for exploratory research and analysis. J. Comput. Chem. 25 (13): 1605-12.

Pierce B.A. (2009) Genética: Un enfoque conceptual. 3ra ed. Editorial Médica Panamericana, Madrid, España.

Qin B., Minter Dykhouse K., Yu J., Zhang J., Liu T., Zhang H., Lee S., Kim J., Wang L., Lou Z. (2015) DBC1 functions as a tumor suppressor by regulating p 53 stability. Cell. Rep. 10:13241334.

Quintela D., López J., Senra A.. La proteína p53 y el cáncer de mama. Revisión crítica. Rev. senol. patol. mamar. (Ed. impr.). 14(2): 71-77

Ramírez G.C., Herrera J.C., Muñeton C.M., Márquez J.R., Isaza L.F. (2008) Análisis de las aneuploidías del cromosoma 17 y deleción del gen TP53 en tumores gastrointestinales por FISH-bicolor. Rev. Col. Gastroenterol. 23 (4): 333-342.

Rangel L., Piña P., Salcedo M. (2006) Variaciones genéticas del gen supresor de tumores TP53: relevancia y estrategias de análisis. Rev. Invest. Clin. 58 (3): 254-264.

Ribeiro R.C., Sandrini F., Figueiredo B., Zambetti G.P., Michalkiewicz E., Lafferty A.R. (2001) An inherited p53 mutation that contributes in a tissue-specific manner to pediatric adrenal cortical carcinoma. Proc. Natl. Acad. Sci. USA 98: 9330-9335. 
Richards S., Aziz N., Bale S., Bick D., Das S., Gastier J. (2015) Standards and guidelines for the interpretation of sequence variants: a joint consensus recommendation of the American College of Medical Genetics and Genomics and the Association for Molecular Pathology. Genet. Med. 17 (5): 405-423.

Richardson R.B. (2013) p53 mutations associated with aging-related rise in cancer incidence rates. Cell cycle 12 (15): 2468-2478.

Risueño P.A. (2012) Bioinformática aplicada a estudios del transcriptoma humano: análisis de expresión de genes, isoformas génicas y ncRNAs en muestras sanas y en cáncer. Tesis Doctoral, Universidad de Salamanca, España.

Roa J.C., Roa I., Araya J.C., Villaseca M., Melo A., Burgos L. (2002) Gen supresor de tumores p53 en neoplasias digestivas. Rev. Med. Chile 128 (11): 1269-1278.

Roa S., Roa I., Araya J.C., Villaseca M.A., Melo A., Burgos L. (2000) Gen supresor de tumores p53 en neoplasias digestivas. Rev. Med. Chile 128 (11): 1269-1278.

Rodrigues N.R., Rowan A., Smith M.E., Kerr I.B., Bodmer W.F., Gannon J.V., Lane D.P. (1990) p53 mutations in colorectal cancer. Proc. Natl. Acad. Sci. USA. 87: 7555-7559.

Rojas M., Salmen S., Berrueta L. (2009) Muerte celular programada: I. Activación y mecanismos de regulación. Rev. Med. Ext. Portuguesa 25, 4 (3): 92-106.

Saavedra K., Valbuena J., Olivare W., Marchant M.J., Rodriguez A., Torres V. (2015) Loss of expression of Reprimo, a p53-induced Cell Cycle arrest gene, correlates with invasive stage of tumor. Progression and p73 expression in Gastric Cancer. Plos One 10 (5): 1-13.

Sánchez M.A. (2006) Cáncer hereditario. 1ra ed. Sociedad Española de Oncología Médica SEOM, Madrid, España.

Shuyer M., Sonja C., Henzen L., Van Der Burg M., Fieret E., Klun J., Foekens J.A., Berns E. (1998) High prevalence of codon 213ArgStop mutations of the TP53 gene in humans ovarian cancer in the southwestern part of the Netherlands. Int. J. Cancer. 76: 299-303.

Sjoeblom T., Jones S., Wood L.D., Parsons D.W., Lin J. (2006) The consensus coding sequences of human breast and colorectal cancers. Science 314: 268-274.

Somers K.D., Merrick M.A., Lopez M.E., Incognito L.S., Schechter G.L., Casey G. (1992) Frequent p53 mutations in head and neck cancer. Cancer Res. 52: 5997-6000.

Sprague B.L., Trentham A., García M., Newcomb P.A., Titus L., Hampton J.M. (2007) Genetic variation in TP53 and risk of breast cancer in a population -based case- control study. Carcinogenesis 28 (8): 1680-1686.
Srivastava S., Zou Z., Pirollo K., Blattner W., Chang E.H. (1990) Germ-line transmission of a mutated p53 gene in a cancer-prone family with Li-Fraumeni syndrome. Nature 348: 747-749.

Surget S., Khoury M.P., Bourdon J.C. (2013) Uncovering the role of p53 splice variants in human malign ancy: a clinical perspective. Onco. Targets Ther. 7: 57-68.

Tomoaki A., Takumi K., Hirotaka O., Ducommun B., Makoto I., Takashi O. (2001) Involvement of the interaction between p21 and PCNA for the maintenance of G2/M after DNA damage. J. Biochem. Chem. 276 (46): 42971-42977.

Tu C., Tan Y.H., Shaw G., Zhou Z., Bai Y., Luo R., Ji X. (2008) Impact of low-frequency hotspot mutation $\mathrm{R} 282 \mathrm{Q}$ on the structure of p53 DNA-binding domain as revealed by crystallography at 1.54 angstroms resolution. Acta Crystallogr. 64: 471-477.

Ubby I., Krueger C., Rosato R., Qian W., Chang J., Sabapathy K. (2019) Cancer therapeutic targeting using mutant-p53-specific siRNAs. Oncogene 38: 3415-3427.

Uniprot Database. URL: http://www.uniprot. org/ [20-06-2016]

Uramoto H., Sugio K., Oyama T., Hanagiri T., Yasumoto K. (2006) P53R2, p53 inducible ribonucleotide reductase gene, correlated with tumor progression of non-small cell lung cancer. Anticancer Res. 26 (2A): 983988.

Valva P., Becker P., Streitemberger P., García M., Rey G., Guzmán C. (2009) Germline TP53 mutations and single nucleotide polymorphisms in children. Medicina (Buenos Aires) [online] 69 (1): 143-147.

Van Rensburg E.J., Engelbrecht S., van Heerden W.F., Kotze M.J., Raubenheimer E.J. (1998) Detection of p53 gene mutations in oral squamous cell carcinomas of a black African population sample. Hum. Mutat. 11: 39-44.

Varley J.M., McGrown G., Thorncroft M., Tricker K.J., Teare M.D. (1995) An extended LiFraumeni kindred with gastric carcinoma and a codon 175 mutation in TP53. J. Med. Genet. 32: $942-945$.

Ward A., Cooper T. (2010) The Pathobiology of splicing. J. Pathol. 220 (2): 152-163.

Yakovlev A., Di Giovanni S., Wang G., Liu W., Stoica B., Faden A. (2004) BOK and NOXA Are Essential Mediators of p53-dependent Apoptosis. J. Biol. Chem. 279 (27): 2836728374 .

Yang X., Lu L. (2015) Expression of HPV-16 E6 Protein and p53 Inactivation Increases the Uterine Cervical Cancer Invasion. Drug Res. 65 (2): 70-73.
Zhang Y., Karas M., Zhao H., Yakar S., Le Roith D (2004) 14-3-3Sigma mediation of cell cycle progression is $\mathrm{p} 53$-independent in response to insulin-like growth fator-1 receptor activation. J. Biol. Chem. 279 (33): 3435334360 .

Zhao K., Chai X., Johnston K., Clements A., Marmorstein R. (2001) Crystal structure of the mouse $\mathrm{p} 53$ core DNAbinding domain at 2.7 Å resolution. J. Biol. Chem. 276: 12120-12127.

\section{ACKNOWLEDGEMENTS}

We thank Enago, an editing brand of Crimson Interactive Inc. that edited sintaxis and spelling in American English. 


\section{THE HUMAN VARIOME PROJECT COUNTRY NODE OF ARGENTINA IN ‡ THE FIRST TWO YEARS OF ACTIVITY: PAST, PRESENT AND FUTURE}

\section{EL NODO ARGENTINO DEL PROYECTO VARIOMA HUMANO EN LOS PRIMEROS DOS AÑOS DE ACTIVIDAD: PASADO, PRESENTE Y FUTURO}

Solano A.R. ${ }^{1,2 *}$, Garrido M. ${ }^{3}$, Mele P.G. ${ }^{1}$, Podestá E.J.', Reichardt J.K.V. ${ }^{4}$

\author{
${ }^{1}$ Instituto de Investigaciones \\ Biomédicas (INBIOMED), Facultad \\ de Medicina, Universidad de \\ Buenos Aires-CONICET, Ciudad \\ Autónoma de Buenos Aires, \\ Argentina. \\ 2 Genotipificación y Cáncer \\ Hereditario, Centro de Educación \\ Médica e Investigaciones Clínicas \\ "Norberto Quirno" (CEMIC), Ciudad \\ Autónoma de Buenos Aires, \\ Argentina. \\ ${ }^{3}$ President of Innocence Project \\ Argentina, Florida, Vicente López, \\ Buenos Aires, Argentina. \\ ${ }^{4}$ Australian Institute of Tropical \\ Health and Medicine, James Cook \\ University, Cairns, Queensland, \\ Australia. \\ Corresponding author: \\ Ángela Rosaria Solano \\ asolano@cemic.edu.ar
}

Cite this article as:

Solano A.R., Garrido M., Mele P.G., Podestá E.J., Reichardt J.K.V. 2019. THE HUMAN VARIOME PROJECT COUNTRY NODE OF ARGENTINA IN THE FIRST TWO YEARS OF ACTIVITY: PAST, PRESENT AND FUTURE. BAG Journal of Basic and Applied Genetics XXX (2): 4l-46.

Received: 11/05/2019

Accepted: 12/06/2019

General Editor: Elsa Camadro

DOI: 10.35407/bag.2019.xxx.02.04

ISSN online version: 1852-6233

\begin{abstract}
A B STR A C T
The Human Variome Project (HVP) is an international effort aiming systematically to collect and share information on all human genetic variants. It has been working for years in collaboration with local scientific societies by establishing systems to collect every genetic variant reported in a country and to store these variants within a database repository: LOVD (Argentinian chapter: ar.lovd.org). Formally established in 2017 in the Argentinian Node, up to June 2019 we collected more than 25,000 genetic variants deposited by 17 different laboratories. Nowadays the HVP country nodes represent more than 30 countries. In Latin America there are four country nodes: Argentina, Brazil, Mexico and Venezuela; the first two interacted recently launching the LatinGen database. In the present work we want to share our experience in applying the HVP project focusing on its organization, rules and nomenclature to reach the goal of sharing genetic variants and depositing them in the Leiden Open Variation Database. Contributing laboratories are seeking to share variant data to gain access all over the country. It is one of our goals to stimulate the highest quality by organizing courses, applying current nomenclature rules, sponsoring lectures in national congresses, distributing newsletter to serve the Argentinian genomics community and to stimulate the interaction among Latin America countries.
\end{abstract}

Key words: Data sharing, Argentinian chapter of LOVD, Human Variome Project (HVP)Argentina

\section{RES UMEN}

El Proyecto Varioma Humano (HVP) es un esfuerzo internacional que tiene como objetivo recopilar y compartir sistemáticamente información sobre todas las variantes genéticas humanas. Hemos estado trabajando durante tres años en colaboración con sociedades científicas locales, mediante el establecimiento de sistemas para recolectar todas las variantes genéticas reportadas en el país y almacenarlas dentro de la base de datos LOVD (capítulo argentino: ar.lovd.org). En el año 2017 fue establecido formalmente el Nodo Argentino del HVP, habiéndose recolectado más de 25.000 variantes genéticas depositadas por 17 laboratorios diferentes hasta junio de 2019. Hoy en día existen al menos 30 nodos del HVP, correspondientes a diferentes países. En América Latina hay cuatro nodos: Argentina, Brasil, México y Venezuela; Los dos primeros interactuaron recientemente lanzando la base de datos LatinGen. En el presente trabajo queremos compartir nuestra experiencia en la aplicación del proyecto HVP centrándonos en su organización, reglas y nomenclatura para alcanzar el objetivo de compartir variantes genéticas y depositarlas en la base de datos de variaciones abiertas de Leiden (LOVD). Es uno de nuestros objetivos estimular la más alta calidad mediante la organización de cursos, aplicación de las reglas de nomenclatura actuales, patrocinio de conferencias en congresos nacionales, distribución de boletines informativos para la comunidad de genómica argentina, y estimulación de la interacción entre los países de América Latina.

Palabras clave: Compartir datos, Nodo argentino de LOVD, Proyecto Varioma Humano (HVP)Argentina. 


\section{INTRODUCTION}

The Human Variome Project (HVP) (Burn and Watson, 2016) is a world-wide organization working to facilitate the collection, curation and interpretation of information on human genetic variation, as well as the free and open sharing of this information. To facilitate these goals, the HVP has created country nodes to support data sharing and facilitating the process of depositing genetic variants. A few reports have been published that shed light on aspects critical for the role of genetics in the current complex situation (Al Aama et al., 2011; Patrinos et al., 2011; Smith and Vihinen, 2015).

The Node of Argentina of the Human Variome Project was launched in November 2017 with the support of the Minister of Health Prof. Dr. Jorge Lemus and his Vice Minister Néstor A. Pérez Baliño, who were very enthusiastic in writing the letters for proposing at the BRCA challenge/UNESCO the creation of our node. A few professionals from different areas joined their experiences in starting the activity and all of them are listed in our web page: https:// humanvariomeprojectargentina.org.ar/. We are running through the generous activity of volunteers who donate their work to manage the activities.

We are proud of the recent formal registration of our node as a Non-Profit Association at the "Inspección General de Justicia", an achievement reached with the assistance of our legal expert, Dr. Manuel Garrido, which will allow us to pursue formal activities with legal requirements.

It is necessary to put in context the current technical and practical situation in the region to explain the Argentinian HVP.

In the past few years the analyses of genetic variants have increased since current technologies allowed to expand sequencing, including in Latin America. Recent reviews (Dutil et al., 2015; Jara et al., 2017) have revealed significant genetic variants heterogeneity among the different countries and in the methodologies and criteria used for selecting patients which are often restricted by the modest available budgets and constrained human resources needed for clinical interpretation. In fact, the initial available data reveals the heterogeneous spectrum of pathogenic variants among the regions and/or countries. This information may improve clinical management and, therefore, improve patient outcomes. In addition, the need for data to support policies for genetic testing in different international regions is what makes this a fundamental contribution through this publication. The reports include a wide variety of methodologies, reflecting the enormous revolution in sequencing technologies over a short time span. Therefore, cautious interpretation of the results is imperative. The publications reviewed revealed a lack of common and recurrent variants in the region. Additionally, there are some Amerindian founder variants for countries like Brazil, Colombia, Mexico, Peru (Ossa and Torres, 2016) and Chile (Alvarez et al., 2017). Applications for Recommended System Status can be made at any time to the ISAC via the ICO (Smith and Vihinen, 2015).

In fact, there was a premonition back in 2008 by Sir John Burn (Burn and Watson, 2016): "The HVP attracted widespread support within the academic community with more than a thousand affiliates at the last count. The underlying concept was to move toward a more formalized curation system based on data shared between country nodes. It was recognized that this would be necessary because of the significant differences between different jurisdictions in terms of data protection legislation, public perception of genetics, research infrastructure, and diagnostic service provision". In the experience of the Argentinian node, we are delighted for the opportunity to put into practice this farsighted philosophy and practice of genetic work, and the extraordinary possibility to extend it to all our colleagues working in genetics in the country.

\section{SEQUENCING TECHNOLOGIES IN LATIN AMERICA, CONTRIBUTION OF THE NODES}

Genetic analyses in Latin America (LA) have increased exponentially in the last few years, albeit not as much as in the rest of the world, the role of our country node is essential as it uniforms the nomenclature by curating the variants reported to be sent to the database (Leiden Open Variation Database, LOVD, in our case), seeks for education in genetics for clinicians and laboratory professionals, stimulates academic activities, all of them to improve the quality of clinical genetic information, as the most important areas.

In our experience an important role of the Argentinian node is to stimulate regional activities, since there is much stimulus to promote the creation of nodes in other countries and, hopefully, gain interactivity among the working groups. An interesting example can be found in the BRCA1/2 gene sequencing, the main focus.

Among the most frequently analyzed genes are the $B R C A 1$ and BRCA2 genes. The information collected thus far is not sufficient to discern the spectrum of genetic variants in the different regions and/or countries. Furthermore, it is becoming important as it may improve clinical practice and subsequently benefit patient outcomes. In addition, the need for data to support 
policies for testing in different international regions is a fundamental strength of the present communication. The different publications included reports with a wide spectrum of methodologies (Alemar et al., 2016; Kehdy et al., 2015; Weitzel et al., 2013), reflecting the fast evolution in sequencing technologies and, thus, a cautious interpretation is imperative to avoid the eventual missing of variants due to the limitations of the methods. Overall results showed very few common variants in Latin America, although the substantial differences in the methodologies are a limitation. In a recent publication of the results published from sixteen laboratory groups in Brazil (Palmero et al., 2018), only five performed full sequencing of both $B R C A 1 / 2$ genes (Alemar et al., 2017; Carraro et al., 2013; Fernandes et al., 2016; Maistro et al., 2016; Silva et al., 2014); the other studies include sequencing selected exons, analyzing only the BRCA1 gene and other various assays.

European ancestry is most prevalent in Argentina (Cardoso et al., 2018; Solano et al., 2012; Solano et al., 2017; Solano et al., 2018), Brazil (Palmero et al., 2018) and Uruguay (Delgado et al., 2011) and the sequencing results of novel and few recurrent variants are consistent with heterogeneity from this admixture. Very importantly, a warning for not blindly importing panels of hotspot genetic variants if not tested before in the local context of regional spectrum of variants. In fact, this contributes to the best interpretation of the genetic results as a crucial part of our educational function, always necessary as described and discussed for Argentina (Solano et al., 2017). It echoes similar findings in Brazil (Alemar et al., 2016) and confirmed the lack of usefulness in the recent compilation of publications (Palmero et al., 2018). There are some Amerindian founder variants identified in countries like Brazil, Colombia, Mexico, Peru (Ossa and Torres, 2016) and Chile (Alvarez et al., 2017), reflecting the local contribution to the genetic spectrum from the native populations, a very important population and epidemiological disclosure.

Even in the recent survey "worldwide snapshot" (Toland et al., 2018), the authors did not receive relevant data from LA (the data in the publication does not represent Latin America; it only includes two laboratories: one each for Argentina and Brazil). The sample surveyed does not represent the actual technological situation in the region and specifically neither of the two Latin American countries both with an HVP country node, that could be of utility to validate the reported data; the rest of the countries were not included in the survey, which consists of an Excel spreadsheet of 65 fields, so the conclusions are extremely limited when it comes to this region. A rescue for this omission was written by 9 laboratories (Argentina, Brazil, Chile, Colombia, Costa Rica, Guatemala, Mexico and Uruguay) with an author from the original study who open the survey for Latino America and we sent for publication in November 2019.
A more realistic overview can be obtained by reviewing databases in the case of Argentina, with 25,064 variants deposited at LOVD, by 17 laboratories from five cities in the country. A brief description of genetic testing in Argentina was recently summarized (Cotignola et al., 2019).

All these technical limitations highlight the importance and the utility of the policies effective worldwide through the leadership of HVP country nodes, including data sharing and practices (Smith and Vihinen, 2015).

\section{ACADEMIC ACTIVITIES OF THE ARGENTINIAN NODE OF THE HUMAN VARIOME PROJECT}

As published (Smith and Vihinen, 2015): "the HVP Consortium works collaboratively to define international standards and guidelines that describe best-practice methodology in each of the areas, which can then be utilized in the implementation of specific systems and processes."

In pursuing the optimal translation of these practices into our professional local community, we organized in Argentina both local meetings and a few international meetings documented in our webpage, www.humanvariomeprojectargentina.org.ar/, as follows:

- Prof. Dr. Johan den Dunnen from the Leiden Open Variation Database, Netherlands participated at the "XLVI Argentine Congress of Genetics and IV Regional Conference SAG-NOA" (Catamarca, Argentina, October 1st-4th, 2017, www.sag.org.ar). He also lectured at "Centro de Educación Médica e Investigaciones Clínicas (CEMIC), October 6th, 2017" resulting very fruitful interaction with the experts present from the most specialized Institutions in hereditary cancer in Argentina.

- Organized by the "Sociedad Argentina de Investigación Clínica" (SAIC) held in Buenos Aires, Argentina, Prof. Dr. Juergen K.V. Reichardt participated, at both levels, interacting with the Community, on November 12th 2017, and the day after at the Annual Congress of SAIC (https:// www.saic.org.ar) as speaker at the Symposia of the Node. The interest of the community in the genetic concepts and the application in health was remarkable, the clarity of Dr. Reichardt was key for the excellent interaction.

- At the International Congress of Genetics (ICG) in Foz do Iguaçu, Brazil, September 10th to 15th, 2018, the Chair of the Node of Argentina, Dr. Angela R. Solano lectured in a Symposium with the participation of three other Latino American scientists. 
- Held in Buenos Aires on November 22nd and 23rd, 2018, the Workshop of the Node of Argentina of the Human Variome Project was a very interactive meeting. The workshop was a success and it is remarkable the interest and enthusiasm of the participants sustained by lectures which updated data including practical implications and application of programs in clinical cases in their own notebooks, skills to be reinforced as they are very critical nowadays due to the permanent advances and the necessity of an updated knowledge through life-long learning.

The importance of the meeting was reinforced by the recognition of Prof. Dr. Johan den Dunnen as Honor Guest for the City Hall of the City of Buenos Aires, on November 21st. For this occasion Dr. den Dunnen gave an impressive presentation on "International Standards for Genetics Nomenclature", held at the Golden Room of the main Palace of the City Hall.

The Argentinian Node was invited to participate of the activities of the Ecuador network for genetics and genomics (Red de Genética y Genómica, ReGG: https:// www.yachaytech.edu.ec/en/regg/) (founded by one of us, JKVR) a year ago to promote research, training, offer continuing education, share expertise, equipment, advice and assessment in Ecuador. This association is made up of two universities, four research institutes and the Secretariat for Science and Technology (SENESCYT; the equivalent of the Science and Technology Ministry in Ecuador).

ReGG has held monthly meetings and also held its first annual meeting in April 2019 in Quito, Ecuador (www. yachaytech.edu.ec/en/noticia/first-regg-annualreunion/). This meeting brought together national and international speakers and paved the way for a bright future for genetics and genomics in Ecuador amongst its 150 participants. It is anticipated that the annual meeting will continue and serve as a conduit for national and regional collaboration as well.

The common activities in Latin American countries will be hopefully shared at LatinGen (www.latingen. org), launched with the colleague from Brazil including the Chair of the Node of Brazil of the Human Variome Project, Dr. Iscia Lopes-Cendes. The aim is to support data-sharing in LA by fostering collaboration and integration among projects in different countries, as follows:

- a) To facilitate the centralization and integration of public databases already established in LA.

- b) To stimulate and support new initiatives by providing technical assistance (bioinformatics expertise) to implement public databases in LA.

- c) To support education and training in the field of human genetic variation in LA.
As it is summarized in the web page of the Argentinian Node: "Latin America and the Caribbean region make up one of the largest areas of the world, and this region is characterized by a complex mixture of ethnic groups sharing Iberian languages. The area is comprised of nations with different levels of social development. This region has experienced historical advances in the last decades to increase the minimal standards of quality of life; however, several factors such as concentrated populations in large urban centers and isolated poor communities still have an important impact on medical services. Latin American researchers have greatly contributed to the development of genetics and historic interethnic diversity and the multiplicity of geographic areas are unique for the study of gene-environment interactions".

\section{DATA SHARING AND GENETIC DEVELOPMENT}

As a round-up concept for this work: data sharing is an international initiative from clinical, medical, and basic research laboratories to systematically identify and document genetic variants (including pathogenic and benign genomic variants) worldwide. Data is provided as gene and/or disease-specific collections, and also as country-specific data, and this effort sustains the country-specific variants listing in the LOVD, for us: ar.lovd.org; we succeeded in improving the translational research strategies and clinical decision-making processes nationally, regionally and beyond. The challenge is ongoing and we look forward to accelerate the production of results taking advantage of the enormous progress in the era of rapidly advancing technologies. Actually, the most critical part may be the decision to be a depositor of all variants detected, an attitude that in some laboratories still is a matter of some hesitation, and the good news is that many new laboratories are incorporated daily into this data sharing effort.

Finally, we mention the updates and alerts about new sand challenges in the worldwide genetics and genomics community, published in the weekly newsletter of the Global Alliance for Genetics and Health (GA4GH; www. ga4gh.org). An important disclosure a few months ago was a description about the current landscape of the direct to consumers (DTC) laboratories: DTC laboratories are enterprises engaged in sequencing DNA of a client sample sent following the instructions of a kit that can be bought at the pharmacies and paid by the consumer, without the necessity of a medical order. The danger arises of its application in diagnostics (press release, March $6^{\text {th }}, 2018$, www.ga4gh.org). A very important matter for the professionals involved is the writing of reports with clinical importance for patients, from 
which medical decisions will be supported, including diagnoses, treatments, surgeries, etc.

\section{REMARKS AND CONCLUSIONS}

The role of the Argentinian node of the HVP is to support the activities in genetics and genomics in every province of Argentina, and we are looking forward to increasing the contribution from all local laboratories involved in gene sequencing. Furthermore, we hope that our work may serve as an inspiration to other countries in the region that still do not have their own nodes, and we are always happy to share our experience to make the implementation of the countries nodes easier and faster.

The launching of the LatinGen database with our colleagues from Brazil is very promising to stimulate the interaction of the region and to join efforts in the genetic development of Latin America countries.

\section{REFERENCES}

Al Aama J., Smith T.D., Lo A., Howard H., Kline A.A., Lange M., Kaput J., Cotton R.G. (2011) Initiating a Human Variome Project Country Node. Hum. Mutat. 32 (5): 501-506.

Alemar B., Gregorio C., Herzog J., Matzenbacher Bittar C., Brinckmann Oliveira Netto C., Artigalas O., Schwartz I.V.D., Coffa J., Alves Camey S., Weitzel J., Ashton Prolla P. (2017) BRCA1 and BRCA2 mutational profile and prevalence in hereditary breast and ovarian cancer (HBOC) probands from Southern Brazil: Are international testing criteria appropriate for this specific population? PLoS One 12 (11): e0187630.

Alemar B., Herzog J., Brinckmann Oliveira Netto C., Artigalas O., Schwartz I.V.D., Matzenbacher Bittar C., Ashton Prolla P., Weitzel J.N. (2016) Prevalence of Hispanic BRCA1 and BRCA2 mutations among hereditary breast and ovarian cancer patients from Brazil reveals differences among Latin American populations. Cancer Genet. 209 (9): 417-422.

Alvarez C., Tapia T., Pérez Moreno E., Gajardo Meneses P., Ruiz C., Ríos M., Missarelli C., Silva M., Cruz A., Matamala L., Carvajal Carmona L., Camus M., Carvallo P. (2017) BRCA1 and BRCA2 founder mutations account for $78 \%$ of germline carriers among hereditary breast cancer families in Chile. Oncotarget 8 (43): 74233-74243.

Burn J., Watson M. (2016) The Human Variome Project. Hum. Mutat. 37 (6): 505-507.

Cardoso F.C., Goncalves S., Mele P.G., Liria N.C., Sganga L., Díaz Pérez I., Podestá E.J., Solano A.R. (2018) BRCA1 and BRCA2 mutations and clinical interpretation in 398 ovarian cancer patients: comparison with breast cancer variants in a similar population. Hum. Genomics $12(1): 39$.

Carraro D.M., Koike Folgueira M.A., García Lisboa B.C., Ribeiro Olivieri E.H., Vitorino Krepischi A.C., de Carvalho A.F., de Carvalho Mota L.D., Puga R.D., Maciel M.S., Michelli R.A., de Lyra E.C., Grosso S.H., Soares F.A., Achatz M.I., Brentani H., Moreira Filho C.A., Brentani M.M. (2013) Comprehensive analysis of BRCA1, BRCA2 and TP53 germline mutation and tumor characterization: a portrait of early-onset breast cancer in Brazil. PLoS One 8 (3): e57581.

Cotignola J., Rozental S., Buzzalino N., Dain L. (2019) Genetics and genomic medicine in Argentina. Mol. Genet. Genomic Med. 7 (4): e00571.

Delgado L., Fernández G., Grotiuz G., Cataldi S., González A., Lluveras N., Heguaburu M., Fresco R., Lens D., Sabini G., Muse I.M. (2011) BRCA1 and BRCA2 germline mutations in Uruguayan breast and breast-ovarian cancer families. Identification of novel mutations and unclassified variants. Breast Cancer Res. Treat. 128 (1): 211-218.

Dutil J., Golubeva V.A., Pacheco Torres A.L., Díaz Zabala H.J., Matta J.L., Monteiro A.N. (2015) The spectrum of BRCA1 and BRCA2 alleles in Latin America and the Caribbean: a clinical perspective. Breast Cancer Res. Treat. 154 (3): 441-453.

Fernandes G.C., Michelli R.A., Galvao H.C., Paula A.E., Pereira R., Andrade C.E., Felicio P.S., Souza C.P., Mendes D.R.P., Volc S., Berardinelli G.N., Grasel R.S., Sabato C.S., Viana D.V., Mauad E.C., Scapulatempo Neto C., Arun B., Reis R.M., Palmero E.I. (2016) Prevalence of BRCA1/BRCA2 mutations in a Brazilian population sample at-risk for hereditary breast cancer and characterization of its genetic ancestry. Oncotarget 7 (49): 80465-80481.

Jara L., Morales S., de Mayo T., Gonzalez Hormazabal P., Carrasco V., Godoy R. (2017) Mutations in BRCA1, BRCA2 and other breast and ovarian cancer susceptibility genes in Central and South American populations. Biol. Res. 50 (1): 35.

Kehdy F.S., Gouveia M.H., Machado M., Magalhaes W.C., Horimoto A.R., Horta B.L., Moreira R.G., Leal T.P., Scliar M.O., Soares Souza G.B., Rodrigues Soares F., Araújo G.S., Zamudio R., Sant Anna H.P., Santos H.C., Duarte N.E., Fiaccone R.L., Figueiredo C.A., Silva T.M., Costa G.N., Beleza S., Berg D.E., Cabrera L., Debortoli G., Duarte D., Ghirotto S., Gilman R.H., Gonçalves V.F., Marrero A.R., Muniz Y.C., Weissensteiner H., Yeager M., Rodrigues L.C., Barreto M.L., Lima Costa M.F., Pereira A.C., Rodrigues M.R., Tarazona Santos E., Brazilian EPIGEN Project Consortium (2015) Origin and dynamics of admixture in Brazilians and its effect on the pattern of deleterious mutations. Proc. Natl. Acad. Sci. USA 112 (28): 8696-8701.

Maistro S., Teixeira N., Encinas G., Katayama M.L., Niewiadonski V.D., Cabral L.G., Marques Ribeiro R., Gaburo Junior N., Ribeiro Chaves de Gouvêa A.C., Carraro D.M., Sabino E.C., Diz M.D., Chammas R., de Bock G.H., Folgueira M.A. (2016) Germline mutations in BRCA1 and BRCA2 in epithelial ovarian cancer patients in Brazil. BMC Cancer 16 (1): 934.

Ossa C.A., Torres D. (2016) Founder and Recurrent Mutations in BRCA1 and BRCA2 Genes in Latin American Countries: State of the Art and Literature Review. Oncologist 21 (7): 832-839.

Palmero E.I., Carraro D.M., Alemar B., Moreira M.A.M., Ribeiro Dos Santos A., Abe Sandes K., Campos Reis Galvão H., Reis R.M., Souza C.P., Campacci N., Achatz M.I., Brianese R.C., da Cruz Formiga M.N., Makdissi F.B., Vargas F.R., Evangelista Dos Santos A.C., Seuanez H.N., Lobo de Souza K.R., Netto C.B.O., Santos Silva P., da Silva G.S., Burbano R.M.R., Santos S., Assumpção P.P., Bernardes I.M.M., Machado Lopes T.M.B., Bomfim T.F., Toralles M.B.P., Nascimento I., Garicochea B., Simon S.D., Noronha S., de Lima F.T., Chami A.M., Bittar C.M., Bines J., Artigalas O., Esteves Diz M.D.P., Lajus T.B.P., Gifoni A.C.L.V.C., Guindalini R.S.C., Cintra T.S., Schwartz I.V.D., Bernardi P., Miguel D., Nogueira S.T.D.S., Herzog J., Weitzel J.N., Ashton Prolla P. (2018) The germline mutational landscape of BRCA1 and BRCA2 in Brazil. Sci. Rep. 8 (1): 9188.

Patrinos G.P., Al Aama J., Al Aqeel A., Al Mulla F., Borg J., Devereux A., Felice A.E., Macrae F., Marafie M.J., Petersen M.B., Qi M., Ramesar R.S., Zlotogora J., Cotton R.G. (2011) Recommendations for genetic variation data capture in developing countries to ensure a comprehensive worldwide data collection. Hum. Mutat. 32 (1): 2-9.

Silva F.C., Lisboa B.C., Figueiredo M.C., Torrezan G.T., Santos E.M., Krepischi A.C., Rossi B.M., Achatz M.I., Carraro D.M. (2014) Hereditary breast and ovarian cancer: assessment of point mutations and copy number variations in Brazilian patients. BMC Med. Genet. 15: 55. 
Smith T.D., Vihinen M. (2015) Standard development at the Human Variome Project. Database (Oxford), 2015.

Solano A.R., Aceto G.M., Delettieres D., Veschi S., Neuman M.I., Alonso E., Chialina S., Chacón R.D., Mariani Constantini R., Podesta E.J. (2012) BRCA1 and BRCA2 analysis of Argentinean breast/ovarian cancer patients selected for age and family history highlights a role for novel mutations of putative southAmerican origin. Springerplus 1: 20.

Solano A.R., Cardoso F.C., Romano V., Perazzo F., Bas C., Recondo G., Santillán F.B., González E., Ábalo E., Viniegra M., Michel J.D., Nuñez L.M., Noblia C.M., Mc Lean I., Canton E.D., Chacon R.D., Cortese G., Varela E.B., Greco M., Barrientos M.L., Ávila S.A., Vuotto H.D., Lorusso A., Podestá E.J., Mando O.G. (2017) Spectrum of BRCA1/2 variants in 940 patients from Argentina including novel, deleterious and recurrent germline mutations: impact on healthcare and clinical practice. Oncotarget 8 (36): 60487-60495.

Solano A.R., Liria N.C., Jalil F.S., Faggionato D.M., Mele P.G., Mampel A., Cardoso F.C., Podestá E.J. (2018) BRCA1 and BRCA2 Mutations Other Than the Founder Alleles Among Ashkenazi Jewish in the Population of Argentina. Front. Oncol. 8: 323.

Toland A.E., Forman A., Couch F.J., Culver J.O., Eccles D.M., Foulkes W.D., Hogervorst F.B.L., Houdayer C., Levy Lahad E., Monteiro A.N., Neuhausen S.L., Plon S.E., Sharan S.K., Spurdle A.B., Szabo C., Brody L.C., BIC Steering Committee (2018) Clinical testing of BRCA1 and BRCA2: a worldwide snapshot of technological practices. NPJ Genom. Med. 3: 7.

Weitzel J.N., Clague J., Martir Negron A., Ogaz R., Herzog J., Ricker C., Jungbluth C., Cina C., Duncan P., Unzeitig G., Saldivar J.S., Beattie M., Feldman N., Sand S., Port D., Barragan D.I., John E.M., Neuhausen S.L., Larson G.P. (2013) Prevalence and type of BRCA mutations in Hispanics undergoing genetic cancer risk assessment in the southwestern United States: a report from the Clinical Cancer Genetics Community Research Network. J. Clin. Oncol. 31 (2): 210-216.

\section{ACKNOWLEDGEMENTS}

We wish to thank for the stimulus in the creation and support of the Node of Argentina of the Human Variome Project to: Prof. Dr. Néstor A. Pérez Baliño (Vice Minister) and Prof. Dr. Jorge D. Lemus (Minister) from the Ministerio de Salud de la República Argentina (2016); Prof. Dr. Miguel Galmés (President) and Elías Hurtado Hoyo (Past-President) of the Asociación Médica Argentina (AMA); Ing. Agr. Dr. Juan Carlos Salerno, President of the Sociedad Argentina de Genética; Dr. Graciela Cremaschi (Past President, 2016) of the Sociedad Argentina de Investigación Clínica (SAIC); Dr. Juan Lacava (Past President, 2016) of the Asociación Argentina de Oncología Clínica (AAOC); Dr. Marcelo Blanco Villalba (Past President, 2016) of the Sociedad de Cancerología; from the Human Variome Project, ISAC: Prof. Dr. Sir John Burn; Prof. Dr. Johan den Dunnen; Prof. Dr. Martina Witsch-Baumgartner and Helen M. Robinson; from CEMIC, the Laboratory of Genotyping: Dr. Florencia C. Cardoso, Dr. Natalia C. Liria, Dr. Fernanda S. Jalil and Dr. Daniela M. Faggionato, all of them also members of the HVP and to the Director of the Departamento de Asistencia Médica, Dr. Oscar Mandó. JKVR is supported by IDFEC, the International Development Fund for Economy and Culture. We are also grateful to the contributors of the Node of Argentina listed on the web page (www.humanvariomeprojectargentina.org.ar). 


\title{
GENOME SIZE IN THREE SPECIES OF Glandularia AND THEIR HYBRIDS ๑
}

\section{TAMAÑO DEL GENOMA EN TRES ESPECIES DE Glandularia Y SUS HÍBRIDOS}

\author{
Ferrari M.R.', Greizerstein E.J., ${ }^{2,}$, Poggio L. ${ }^{4 *}$
}

\author{
1 Facultad de Ciencias Veterinarias, \\ INITRA, UBA, CABA, Argentina. \\ 2 Cátedra de Mejoramiento \\ Genético, Facultad de Ciencias \\ Agrarias, UNLZ, Buenos Aires, \\ Argentina. \\ ${ }^{3}$ Instituto de Investigaciones \\ en Producción Agropecuaria, \\ Ambiente y Salud (IIPAAS-FCA-CIC), \\ Argentina. \\ ${ }^{4}$ IEGEBA (UBA-CONICET) Dpto. de \\ Ecología, Genética y Evolución, \\ FCEN, CABA, Argentina. \\ Corresponding author: \\ Lidia Poggio \\ lidialidgia@yahoo.com.ar
}

Cite this article as:

Ferrari M.R., Greizerstein E.J., Poggio L. 2019. GENOME SIZE IN THREE SPECIES OF Glandularia AND THEIR HYBRIDS. BAG. Journal of Basic and Applied Genetics XXX (2): 47-54.

Received: 07/19/2019

Revised version received: 11/23/2019 Accepted: 12/10/2019

General Editor: Elsa Camadro

DOI: 10.35407/bag.2019.xxx.02.05

ISSN online version: 1852-6233

\section{ABSTRACT}

In this work the relationship between genome size of Glandularia species and the meiotic configurations found in their hybrids are discussed. Glandularia incisa (Hook.) Tronc., growing in two localities of Corrientes and Córdoba provinces, Argentina, with different ecological conditions, showed inter-population variability of the $2 \mathrm{C}$-value. The DNA content found in the Corrientes locality $(2.41 \mathrm{pg})$ was higher than that obtained in the Córdoba locality (2.09 pg) which has more stressful environmental conditions than the former. These values are statistically different from those that were found in Glandularia pulchella (Sweet) Tronc. from Corrientes (1.43 pg) and in Glandularia perakii Cov. et Schn from Córdoba (1.47 pg). The DNA content of the diploid $\mathrm{F}_{1}$ hybrids, G. pulchella $\times$ G. incisa and G. perakii $\times$ G. incisa, differed statistically from the DNA content of the parental species, being intermediate between them. Differences in the frequency of pairing of homoeologous chromosomes were observed in the hybrids; these differences cannot be explained by differences in genome size since hybrids with similar DNA content differ significantly in their meiotic behavior. On the other hand, the differences in the DNA content between the parental species justify the presence of a high frequency of heteromorphic open and closed bivalents and univalents with different size in the hybrids.

Key words: Intra-specific DNA content variability, homoeologous pairing, heteromorphic bivalents.

\section{RESUMEN}

En el presente trabajo se discute la relación entre el tamaño del genoma en especies de Glandularia y las configuraciones meióticas encontradas en sus híbridos. El valor $2 \mathrm{C}$ mostró variabilidad interpoblacional en muestras de Glandularia incisa (Hook.) Tronc. coleccionadas en dos localidades con diferentes condiciones ecológicas (provincias de Corrientes y Córdoba, Argentina). El contenido de ADN encontrado en Corrientes (2,41 pg) fue mayor que el obtenido en Córdoba $(2,09$ pg) donde se registran condiciones ambientales más estresantes. Estos valores son estadísticamente diferentes de los determinados en Glandularia pulchella (Sweet) Tronc. de Corrientes (1.43 pg) y en Glandularia perakii Cov. et Schn de Córdoba (1.47 $\mathrm{pg}$ ). El contenido de $\mathrm{ADN}$ de los híbridos diploides $\mathrm{F}_{1}$, G. pulchella $\times$ G. incisa y G. perakii $\times$ G. incisa, difirió estadísticamente del contenido de ADN registrado en las especies parentales siendo intermedio entre ellas. Las diferencias observadas en la frecuencia de apareamiento de cromosomas homeólogos no pueden explicarse por diferencias en el tamaño del genoma, ya que híbridos con un contenido de ADN similar difieren significativamente en su comportamiento meiótico. Sin embargo, la diferencia en el contenido de ADN entre las especies parentales explica la presencia de una alta frecuencia de bivalentes heteromórficos tanto abiertos como cerrados y univalentes con diferentes tamaños.

Palabras clave: Variabilidad intra-específica del contenido de ADN, apareamiento homoeólogo, bivalentes heteromórficos. 


\section{INTRODUCTION}

Genome size varies among species and its diversification accompanies the evolution of many groups of plants (Bennett and Leitch, 2005; Leitch et al., 2005; Gregory et al., 2007; Leitch and Leitch, 2013; Poggio et al., 2014). Significant variation in DNA content was found among species of the same genera, among populations of one species or even among individuals belonging to the same population or cultivar (Cavallini and Natalli, 1991; Grehilhuber and Leitch, 2013; Realini et al., 2016).

Variation in genome size arises by increase and/ or decrease of DNA content. The increase arises predominantly through polyploidy and amplification of non-coding repetitive DNA heterochromatin and retrotransposons. Moreover, recombination-based processes are mechanisms involved in decrease in genome size or genome downsizing (Soltis et al., 2003; Bennetzen et al., 2005; Grover and Wendel, 2010; Hidalgo et al., 2017). Besides, numerical polymorphism of B-chromosomes can modify the size of the genome (Kalendar et al., 2000; Gregory, 2004; Bennet and Leitch, 2005; Grehilhuber and Leitch, 2013; Fourastié et al., 2018).

Several studies reported some relationships between the DNA content and phenotypic characteristics such as cell size, duration of the cell cycle, growth rate, leaf expansion, flowering time, weediness, invasiveness, seed weight, and minimum generation time (Grime and Mowforth, 1982; Bennett, 1987; Ohri and Pistrick, 2001; Beaulieu et al., 2007; Greihuber and Leitch, 2013; Leitch and Leitch, 2013; Fourastie et al., 2018).

Genome size was also associated with ecological parameters (temperature, precipitation and length of the growing season) and geographical parameters (altitude and latitude) (Greihuber and Leitch, 2013; Fourastie et al., 2018). These correlations suggest a biological role for genome size or "nucleotype", term coined to describe the condition of the nucleus that affects the phenotype independently of the informational content of the DNA (Bennett, 1971; 1972).

Glandularia J.F. Gmel is a genus of the Verbenaceae family composed of $c a .100$ species with a North-South American disjoint distribution (O'Leary and Peralta, 2007; Peralta and Múlgura, 2011). Many of these species, their hybrids and polyploids have great ornamental potential due to their colourful flowers, long flowering period and low water requirements (Imhof et al., 2013; González Roca et al., 2015). The chromosome numbers of numerous species have been studied, and it was found that the South American species are mostly diploid $(2 \mathrm{n}=2 \mathrm{x}=10)$ whereas the North American species are hexaploid $(2 n=6 x=30)$ or tetraploid $(2 n=4 x=20)$ (Schnack and Covas, 1945; Solbrig et al., 1968; Umber, 1979; Poggio et al., 1993; 2016; Turner and Powell, 2005).

Schnack and Solbrig (1953) and Solbrig et al. (1968) carried out an extensive hybridization program between
South American species of the genus Glandularia and recently, many artificial hybrids were obtained with ornamental purposes (Imhof, 2014).

Poggio et al. (2016) analysed G. pulchella $\times$ G. incisa $F_{1}$ natural hybrids observing variability in the frequency of bivalents and univalents. They also reported the presence of heteromorphic bivalents and differences in the size of univalents.

In the present work, DNA content and its variations are reported for the first time in G. pulchella, G. incisa, G. perakii and their $F_{1}$ hybrids, G. pulchella $\times$ G. incisa and G. perakii $\times G$. incisa, species and their hybrids have the same chromosome number (2n=10) (Poggio et al. 2011; Poggio et al., 2016). Moreover, the effect of DNA content of the parental species on meiotic pairing of homoeologous chromosome in the natural hybrids is discussed. These studies could shed light on the biological importance of variation in genome size and processes of hybrid speciation.

\section{MATERIALS AND METHODS}

Glandularia incisa, G. pulchella and their natural hybrids (HA1, HA2, HA3, and HA4): Argentina, province of Corrientes, Dpto. Capital, Aeropuerto Cambá Punta.

G. incisa, G. perakii and their natural hybrids (HB1): Argentina, province of Córdoba, Embalse Río Tercero.

Taxonomic identification of the species and natural hybrids was made according to morphological criteria described by Poggio et al. (1993).

Herbarium materials were deposited in Facultad de Ciencias Exactas y Naturales, Universidad de Buenos Aires, Ciudad Autónoma de Buenos Aires, Argentina.

The distance between Corrientes Dpto. Capital and Embalse Río Tercero is $726 \mathrm{Km}$. Geografical and ecological differences between the two localities are presented in Table 1 (Cabrera, 1976).

\section{Meiotic studies}

These studies were done in inmature flowers fixed in 3:1 (ethanol: acetic acid). The anthers were squashed in $2 \%$ acetic haematoxylin as stain and $1 \%$ ferric citrate as mordant (Nuñez, 1968). In the present paper at least 50 Metaphase I were studied in the parental species and in G. perakii $\times$ G. incisa natural hybrid (HB1). The meiotic determinations made in G. pulchella $\times$ G. incisa were taken from Poggio et al. (2016). Hybrids HA1, HA2, HA3 and $\mathrm{HA}_{4}$ in the present paper correspond, respectively to the hybrids named H5, H8, H9, H4 by Poggio et al. (2016).

\section{Feulgen staining and cytophotometry}

DNA content was measured in meiotic cells stained with the Feulgen Reaction. Inmature flowers were fixed 
in 3:1 (ethanol: acetic acid). The staining method was performed as described in Naranjo et al. (1998) and the measurements of DNA content were done in telophase I nuclei (2C). The amount of Feulgen staining per nucleus, expressed in arbitrary units, was measured at a wavelength of $570 \mathrm{~nm}$ using the scanning method in a Zeiss Universal Micro spectrophotometer (UMSP 30). The DNA content expressed in picograms was calculated using Allium cepa Ailsa Craig as a standard (2C-DNA=33.55 pg; Bennett and Smith, 1976).

\section{Statistical analysis}

Differences in DNA content were tested through analysis of variance (ANOVA) and multiple contrasts were performed with the LSD Fisher method (Fisher, 1932). These statistical analyses were considered significant if $P$ values were $<0.05$ and were performed using the Infostat program, FCA, National University of Córdoba (Di Rienzo et al., 2015).

Table 1. Ecological conditions in Corrientes Dpto. Capital, Province of Corrientes, Argentina and in Embalse Río Tercero Province of Córdoba, Argentina.

\begin{tabular}{|c|c|c|}
\hline & \multicolumn{2}{|c|}{ Localities } \\
\hline & $\begin{array}{c}\text { Corrientes Dpto. } \\
\text { Capital }\end{array}$ & $\begin{array}{c}\text { Embalse Río } \\
\text { Tercero }\end{array}$ \\
\hline $\begin{array}{c}\text { Phytogeographic } \\
\text { Regions }\end{array}$ & $\begin{array}{l}\text { Provincia } \\
\text { Chaqueña }\end{array}$ & $\begin{array}{l}\text { Provincia del } \\
\text { Espinal }\end{array}$ \\
\hline Latitude & $27^{\circ} 47^{\prime} \mathrm{S}$ & $38^{\circ} 18^{\prime} \mathrm{S}$ \\
\hline Altitude & 63 m.a.s.1. & 387 m.a.s.l. \\
\hline $\begin{array}{c}\text { Average } \\
\text { precipitation/year }\end{array}$ & $1249 \mathrm{~mm}$ & $783 \mathrm{~mm}$ \\
\hline $\begin{array}{l}\text { Average Maximal } \\
\text { temperature } \\
\text { (January) }\end{array}$ & $33.5^{\circ} \mathrm{C}$ & $30.4^{\circ} \mathrm{C}$ \\
\hline $\begin{array}{l}\text { Average Minimal } \\
\text { temperature (July) }\end{array}$ & $11^{\circ} \mathrm{C}$ & $2.8^{\circ} \mathrm{C}$ \\
\hline Soil characteristics & $\begin{array}{l}\text { Clay soils with } \\
\text { high moisture }\end{array}$ & $\begin{array}{c}\text { Stony soils with } \\
\text { low humidity }\end{array}$ \\
\hline
\end{tabular}

\section{RESULTS}

The 2C-DNA content of G. pulchella and G. incisa and their hybrids collected in the Province of Corrientes showed significant differences $\left(\mathrm{F}_{6.76}=20.83 ; \mathrm{P}<0.0001\right)$.
Contrasts performed with the LSD Fisher method are presented in Table 2.

Table 2. Nuclear DNA content in G. pulchella, G. incisa, and G. pulchella $x G$. incisa, collected in Province of Corrientes, Argentina. Means with the same letters are not significantly different $(P \leq 0.05)$. $P u=G$. pulchella, $\mathrm{In}=\mathrm{G}$. incisa and $\mathrm{HAl}-\mathrm{HA} 4=G$. pulchella $\times \mathrm{G}$. incisa.

\begin{tabular}{cccc}
\hline Material & $\begin{array}{c}\text { 2C-DNA } \\
\text { (pg) } \\
\text { mean } \pm \text { SE }\end{array}$ & $\begin{array}{c}\text { Number } \\
\text { of cells } \\
\text { studied }\end{array}$ & $\begin{array}{c}\text { Mean value } \\
\text { (pg) } \\
\text { mean } \pm \text { SE }\end{array}$ \\
\hline G. pulchella & & & \\
Pu1 & $1.45 \pm 0.03^{\mathrm{AB}}$ & 25 & \\
$\mathrm{Pu} 2$ & $1.52 \pm 0.02^{\mathrm{A}}$ & 25 & $1.43 \pm 0.06$ \\
$\mathrm{Pu} 3$ & $1.31 \pm 0.03^{\mathrm{B}}$ & 17 & \\
& & &
\end{tabular}

G. incisa

$\begin{array}{llll}\text { In1 } & 2.34 \pm 0.12^{\mathrm{E}} & 25 & \\ \operatorname{In} 3 & 2.29 \pm 0.05^{\mathrm{E}} & 25 & 2.41 \pm 0.10 \\ \operatorname{In} 2 & 2.30 \pm 0.06^{\mathrm{E}} & 25 & \\ \text { In4 } & 2.71 \pm 0.05^{\mathrm{F}} & 25 & \end{array}$

Hybrid

$\begin{array}{llll}\text { HA1 } & 1.84 \pm 0.05^{\mathrm{C}} & 36 & \\ \text { HA2 } & 1.78 \pm 0.05^{\mathrm{C}} & 25 & 1.87 \pm 0.06 \\ \text { HA3 } & 1.81 \pm 0.13^{\mathrm{C}} & 25 & \\ \text { HA4 } & 2.04 \pm 0.03^{\mathrm{D}} & 33 & \end{array}$

The 2C-DNA content of G. perakii, and G. incisa, and their hybrids collected in the Province of Córdoba showed significant differences $\left(\mathrm{F}_{9.127}=44.85 ; \mathrm{P}<0.0001\right)$. Contrasts performed with the LSD Fisher method are presented in Table 3. Numerical polymorphism for B chromosomes was detected in G. incisa, G. perakii and hybrids collected in the Córdoba locality. DNA content was determined only in plants without $\mathrm{B}$ chromosomes for a better comparison with plants from other localities.

Intra-populational significant differences $(\mathrm{P}<0.001)$ were detected in the three species and in their hybrids studied in the present work. Inter-populational significant differences $(\mathrm{P}<0.001)$ were detected between G. incisa collected in the provinces of Corrientes and Córdoba. In Figure 1, a graphic representation is 
presented of 2C-DNA content of the parental species and their hybrids in collections made in the provinces of Corrientes (A) and Córdoba (B). The DNA content of the hybrids, G. pulchella $\times$ G. incisa and G. perakii $\times$ G. incisa was intermediate between the parental species (Table 1, Table 2 and Figure 1). DNA content of HA1, HA2, and $\mathrm{HA} 3$, did not show significant differences among them, but they differed from that of HA4.

The three parental species presented five homomorphic bivalents in all Metaphase I (more than $\mathrm{n}=50$ cells were studied in each species) (Figure $2 \mathrm{a}$ and b). The hybrids had univalents of different size and up to five heteromorphic bivalents (Figure $2 \mathrm{c}-\mathrm{f}$ ).

The mean frequency and standard deviation of bivalents in the natural hybrids G. pulchella $\times$ G. incisa was HA1: $4.98 \pm 0.16, \mathrm{HA2}: 5.00 \pm 0.00, \mathrm{HA3}: 2.80 \pm 1.21$ and HA4: $3.50 \pm 0.72$. HA1 and HA2 did not present significant differences between them (Poggio et al., 1993).

Table 3. Nuclear DNA content in G. perakii, G. incisa and G. perakii x G. incisa collected in Province of Córdoba, Argentina. Means with the same letters are not significantly different $(P \leq 0.05)$. $P e=G$. perakii, In $=G$. incisa and $\mathrm{HBl}=\mathrm{G}$. perakii $\times \mathrm{G}$. incisa.

\begin{tabular}{cccc} 
Material & $\begin{array}{c}\text { 2C-DNA (pg) } \\
\text { mean } \pm \text { SE }\end{array}$ & $\begin{array}{c}\text { Number } \\
\text { of cells } \\
\text { studied }\end{array}$ & $\begin{array}{c}\text { Mean value } \\
(\mathrm{pg}) \\
\text { mean } \pm \mathrm{SE}\end{array}$ \\
\hline
\end{tabular}

G. perakii

$\begin{array}{lccc}(\mathrm{Pe} 1) & 1.39 \pm 0,03^{\mathrm{A}} & 25 & \\ (\mathrm{Pe} 2) & 1.36 \pm 0.05^{\mathrm{A}} & 20 & \\ (\mathrm{Pe} 3) & 1.55 \pm 0.07^{\mathrm{B}} & 17 & 1.47 \pm 0.06 \\ (\mathrm{Pe} 4) & 1.57 \pm 0.05^{\mathrm{B}} & 16 & \end{array}$

G. incisa

\begin{tabular}{|c|c|c|c|}
\hline In5 & $2.04 \pm 0.08^{\mathrm{C}}$ & 20 & \\
\hline In6 & $2.24 \pm 0.04^{\mathrm{D}}$ & 20 & \\
\hline In7 & $2.08 \pm 0.04^{\mathrm{E}}$ & 20 & $2.09 \pm 0.10$ \\
\hline In8 & $2.00 \pm 0.05^{\mathrm{E}}$ & 20 & \\
\hline
\end{tabular}

Hybrid

HB1

$1.76 \pm 0.04^{\mathrm{F}}$

25

$1.76 \pm 0.06$

\section{DISCUSSION}

Significant differences in the DNA content of G. incisa with G. pulchella and G. perakii were found. The mean DNA $2 \mathrm{C}$-values and the variation ranges were determined in G. incisa $2.25 \mathrm{pg}$ (2.00 pg - 2.71 pg), G. pulchella $1.43 \mathrm{pg}$ (1.31 pg-1.52 pg) and G. perakii $1.47 \mathrm{pg}(1.36 \mathrm{pg}-1.57 \mathrm{pg})$. According to the Kew DNA C-values, these are the first reports for genus Glandularia. These values are between the minimum value (Tectona grandis $0.96 \mathrm{pg}$ ) and the maximum value (Lantana camara $5.50 \mathrm{pg}$ ) determined in five species belonging to different genera of the Verbenaceae family (RBG Kew DNA C-values, 2017).

Inter-population variability of the $2 \mathrm{C}$-value was observed in G. incisa growing in two localities with different geographical and ecological conditions (Corrientes and Córdoba Provinces). The values of DNA content obtained in both localities differed significantly and the $2 \mathrm{C}$ values determined in the Corrientes population were $15 \%$ greater than that reported in the Córdoba population. The population of G. incisa with the smaller genome was found in drier and more stressful conditions. These results are in agreement with the reported in different studies, suggesting that variation in DNA amount has adaptive significance related to environmental, climatic and phenological parameters such as temperature, precipitation, length of growing season and type of soil (Bennett, 1987, reviewed in Grehilhuber and Leitch, 2013). Another important difference between the two populations is that G. incisa growing in Córdoba presented polymorphism for $\mathrm{B}$ chromosomes (0-6 B's) whereas B chromosomes were not detected in plants growing in Corrientes. However, this fact does not affect the comparisons performed because measurements in the Córdoba population were carried out in cells without B chromosomes.

In addition to the interpopulation variation reported in this paper, the three species showed intrapopulation variability. The origin of this variation in the nuclear DNA content would be the result of a fraction potentially unstable such as transposable elements subject to environmental and/or genetical events that induce deletion and amplification of sequences (Grover and Wendel, 2010).

It is usually expected that the DNA content of interspecific hybrids were in an intermediate range between the respective parental species, although different authors have found, in some cases, that hybrids have more or less DNA content than their parents. This would be indicating the occurrence of genetic and epigenetic changes that were reported in newly-formed hybrids in several groups of plants (Rayburn et al., 1993; Grattapaglia and Bradshaw, 1994; Ma and Gustafson, 2005). 

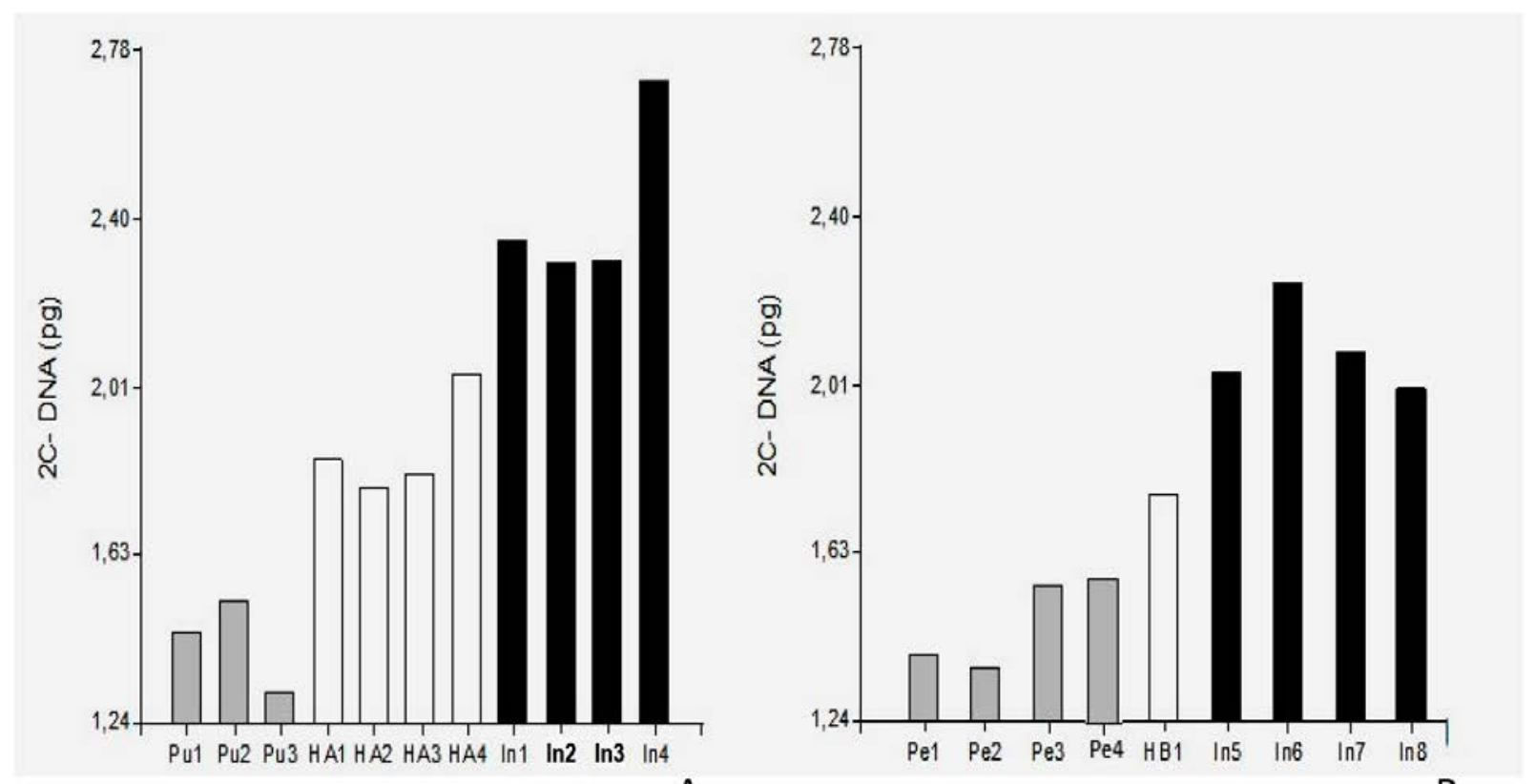

A

\begin{abstract}
Figure 1. Graphic comparison of 2C-DNA content in G. pulchella, G. perakii, G. incisa and the hybrids G. pulchella x G. incisa and G. perakii $\times$ G. incisa.

A) Materials collected in the Province of Corrientes: G. pulchella (Pu, grey); G. Incise (In, black), hybrids (HA, white).

B) Materials collected in the Province of Córdoba. G. perakii (Pe, grey); G. incisa (In, black); hybrid (HB, white). Different numbers indicate

different individuals in each taxa.
\end{abstract}

The natural $\mathrm{F}_{1}$ hybrids G. pulchella $\times$ G. incisa and G. perakii $\times$ G. incisa, analyzed in the populations of Corrientes and Córdoba, have intermediate 2C-DNA values between the parental values and differed statistically from them.

Differences in DNA content are usually correlated with karyotype parameters and can affect the entire chromosome complement or they may be restricted to a subset of chromosomes. So far, the G. incisa, G. pulchella and G. perakii karyotypes have been analysed (data not published) and all of them show metacentric chromosomes, being larger the chromosomes of G. incisa. This leads us to suggest that changes in DNA content occurred in the whole-chromosome complement adding or losing equal DNA amounts to both arms or in the pericentromeric region, maintaining their metacentric morphology (in preparation).

Solbrig et al. (1968) made artificial crosses between species of Glandularia and observed homoeologous pairing in $\mathrm{F}_{1}$ hybrids and suppression of homoeologous pairing in the allotetraploids. Poggio et al. (2016) reported that the $F_{1}$ hybrids G. pulchella $\times$ G. incisa had variability in homoeologous pairing forming from one to five heteromorphyc bivalents and univalents of different size. These authors explained the homoeologous pairing in the $F_{1}$ hybrids by suggesting the presence of a pairing regulator gene/s that precluded homoeologous pairing when homologous genomes are in two doses in the polyploids, and display incomplete penetrance when homologous genomes are in one dose in the diploids.

The differences in DNA content found in the parental genomes could explain the presence of heteromorphic bivalents in the $F_{1}$ hybrids. However, the genome size cannot explain the differences observed in homoeologous pairing since hybrids with similar DNA content differed significantly in their meiotic behavior.

The differences in the frequency of pairing of homoeologous chromosomes that were observed in the hybrids cannot be explained by the genome, size of the parental species, since hybrids with similar DNA content differed significantly in their meiotic behavior. On the other hand, the differences in the DNA content between the parental species could justify the presence of a high frequency of heteromorphic open and closed bivalents as well as univalents with different size in the hybrids. 

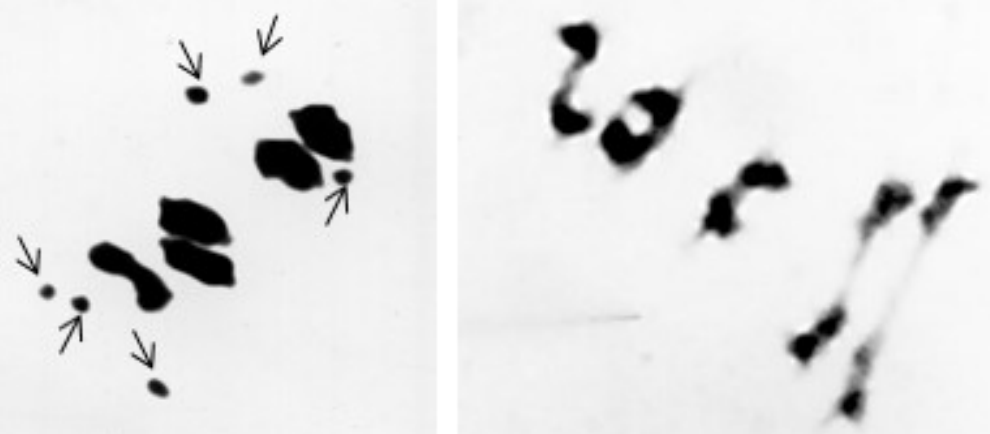

a

b

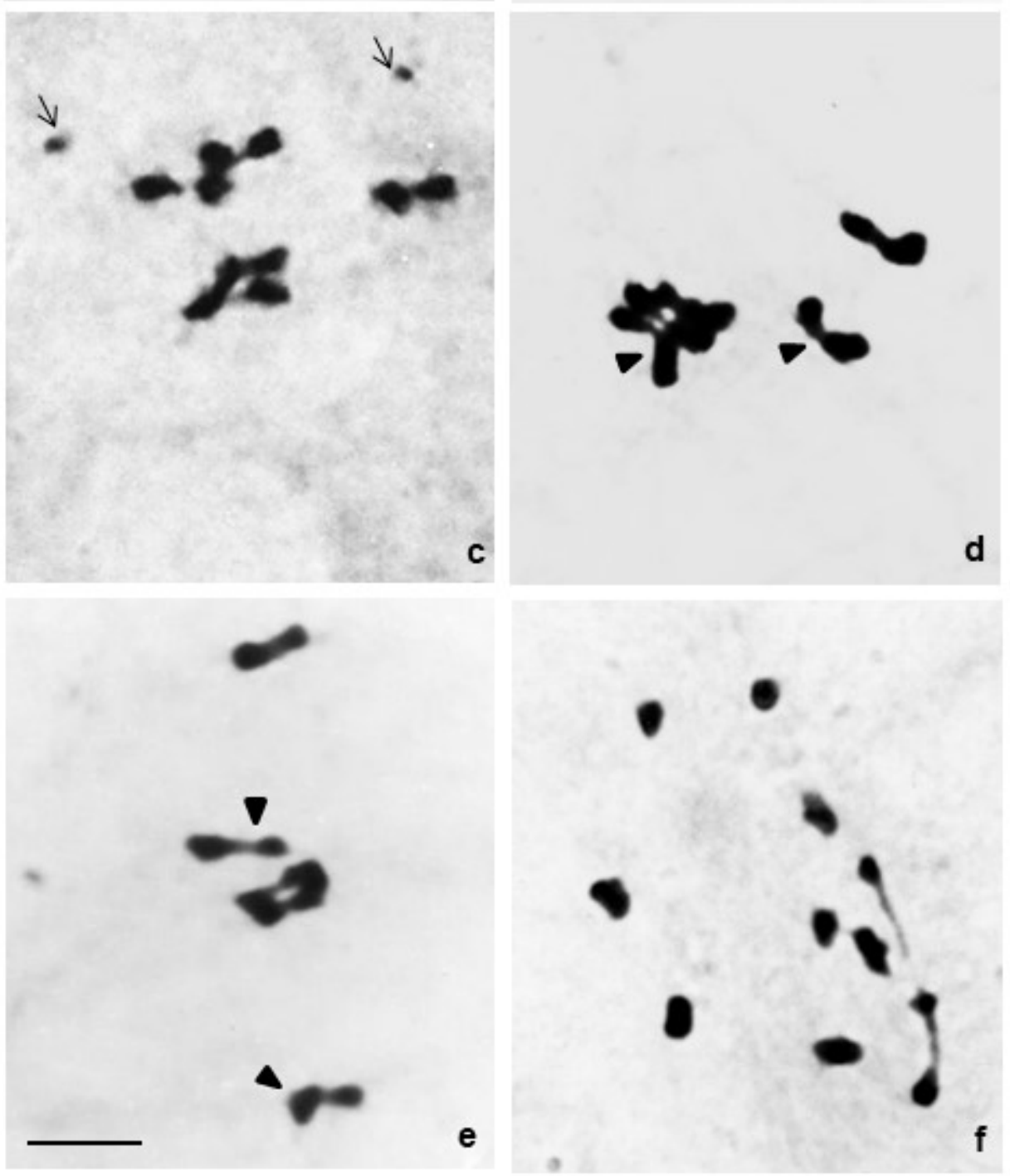

Figure 2. Metaphase I in Glandularia species and $F_{1}$ hybrids.

a) G. incisa (collected in Córdoba) with five homomorphic bivalents and six B chromosomes.

b) G. pulchella with five homomorphic bivalents.

C-f) hybrids with univalents and heteromorphic bivalents. c) G. perakii $\times$ G. incisa with two B chromosomes and five heteromorphic bivalents. d) G. perakii $\times$ G. incisa with five heteromorphic bivalents. e) $G$. pulchella $\times$ G. incisa with five heteromorphic bivalents. f) $G$. pulchella $\times G$. incisa with one heteromorphic bivalent and eight univalents. Arrows show B chromosomes and arrow heads indicate some notorious heteromorphic bivalents. Bars $10 \mu \mathrm{m}$. 


\section{REFERENCES}

Beaulieu J.M., Moles A.T., Leitch I.J., Bennett M.D., Dickie J.B., Knight C.A. (2007) Correlated evolution of genome size and seed mass. New Phytol. 173: 422-437.

Bennett M.D. (1971) The duration of meiosis. Proc. Royal Soc. Lond. Volume 178, issue 1052 .

Bennett M.D. (1972) Nuclear DNA content and minimum generation time in herbaceous plants. Proc. Royal Soc. Lond. B 181: 109-135.

Bennett M.D. (1987) Variation in genomic form in plants and its ecological implications. New Phytol. 106: 177-200.

Bennett M.D., Smith J.B. (1976) Nuclear DNA amounts in angiosperms. Philos. Trans. Royal Soc. B 274: 227-274.

Bennett M.D., Leitch I.J. (2005) Plant genome size research: a field focus. Ann. Bot. 95 (1): 1-6.

Bennetzen J.L., MA J., Devos K.M. (2005) Mechanisms of Recent Genome Size Variation in Flowering Plants. Ann. Bot. 5: 127-132.

Cabrera A.L. (1976) Regiones Fitogeográficas Argentinas. En: Enciclopedia Argentina de Agricultura y Jardinería. Editorial Acme, Buenos Aires, Argentina: Tomo II (1): 1-85.

Cavallini A., Natali L. (1991) Intraspecific variation of nuclear DNA content in plant species. Caryologia 44: 93-107.

Di Rienzo J.A., Casanoves F., Balzarini M.G., González L., Tablada M., Robledo C.W. (2015) InfoStat versión 2015. Grupo InfoStat, FCA, Universidad Nacional de Córdoba, Argentina. URL http://www.infostat.com.ar.

Fisher R.A. (1932) Statistical methods for research workers, 4th ed. Edinburgh: Oliver and Boyd.

Fourastié M.F., Gottlieb A.M., Poggio L., González G.E. (2018) Are cytological parameters of maize landraces (Zea mays ssp. mays) adapted along an altitudinal cline? J. Pl. Res. 131: 285.

González Roca L., Iannicelli J., Coviella A., Bugallo V., Bologna P., Pitta-Álvarez S., Escandón A. (2015) A protocol for the in vitro propagation and polyploidization of an interspecific hybrid of Glandularia (G. peruviana $\times$ G. scrobiculata). Scientia Horticulturae 184: 46-54

Grattapaglia D., Bradshaw Jr. H.D. (1994) Nuclear DNA content of commercially important Eucalyptus species and hybrids. Can. J. For. Res. 24: 1074-1078.

Gregory T.R. (2004) Macroevolution, hierarchy theory, and the $\mathrm{C}$-value enigma. Paleobiology 30: 179-202.
Gregory T.R., Nicol J.A., Tamm H., Kullman B., Kullman K., Leitch I.J., Murray B.G., Kapraun D.F., Greilhuber J., Bennett M.D. (2007) Eukaryotic genome size databases. Nucleic Acids Res. 35 (suppl. 1): D332-D338.

Greilhuber J., Leitch I.J. (2013) Genome size and the phenotype. In: Leitch I.J., Greilhuber J., Dolezel J., Wendel J.F. (Eds.) Plant genome diversity, Vol. 2. Vienna: Springer, pp. 323-340.

Grime J.P., Mowforth M.A. (1982) Variation in genome size an ecological interpretation. Nature 299: 151-153.

Grover C.E., Wendel J.F. (2010) Recent insights into mechanisms of genome size change in plants. J. of Botany Vol. 2010, Article ID 382732: 1-8.

Hidalgo O., Pellicer J., Christenhusz M., Schneider H. (2017) Is there an upper limit to genome size? Trends Plant ScI. 22 (7), DOI 10 1016/j.tplants.2017.04.005

Imhof L, Suarez M, Paganelli F, Facciuto G. (2013) Interspecific hybridization among three species of Glandularia (Verbenaceae) native to Argentina. Acta Horticulturae 1000:481-486

Imhof L. (2014) Bases para el mejoramiento de Glandularia con fines ornamentales. $\mathrm{PhD}$ Thesis Universidad Católica de CórdobaINTA, Argentina.

Kalendar R., Tanskanen J., Immonen S., Nevo E., Schulman A.H. (2000) Genome evolution of wild barley (Hordeum spontaneum) by BARE1 retrotransposon dynamics in response to sharp microclimatic divergence. Proc. Natl. Acad. Sci. 97: 6603-6607.

Leitch I.J., Leitch A.R. (2013) Genome size diversity and evolution in land plants. In: Leitch I.J., Greilhuber J., Dolezel J., Wendel J.F. (Eds.) Plant Genome Diversity, Vol. 2. Springer, Vienna, pp. 307-322.

Leitch I.J., Soltis D.E., Soltis P.S., Bennett M.D. (2005) Evolution of DNA amounts across land plants (Embryophyta). Ann. Bot. 95: 207-217.

Ma X.F., Gustafson J.P. (2005) Genome evolution of allopolyploids: a process of cytological and genetic diploidization. Cytogenet. Genome Res. 109: 236-249.

Naranjo C.A., Ferrari M.R., Palermo A.M., Poggio L. (1998) Karyotype, DNA content and meiotic behaviour in five South American Species of Vicia (Fabaceae). Ann. Bot. 82: 757-764.

Nuñez O. (1968) An acetic-haematoxilin squash method for small chromosomes. Caryologia 21: 115-119.

O'Leary N., Peralta P. (2007) Nuevas combinaciones en el género Glandularia (Verbenaceace). Darwiniana 45: 218-230.
Ohri D., Pistrick K. (2001) Phenology and Genome Size Variation in Allium L. - a Tight Correlation? Plant Biol. (Stuttg) 3 (6): 654660

Peralta P.F., Múlgura M.E. (2011) El Género Glandularia (Verbenaceae) en Argentina. Ann. Missouri Bot. Gard. 98: 358-412.

Poggio L., Botta S.M., Greizerstein E.J., Ferrari M.R. (1993) Natural hybridization in Glandularia (Verbenaceae). Evolutionary implications of chromosome pairing. Darwiniana 32: 77-90.

Poggio L., Ferrari M.R., Greizerstein E.J. (2011) Variabilidad genética y epigenética en híbridos naturales y artificiales de Glandularia. XL Congreso Argentino de Genética, III Simposio Latinoamericano de Citogenética y Evolución, I Jornadas Regionales SAG-NEA. Corrientes 18-21 de septiembre de 2011. BAG XLI: 129.

Poggio L., Greizerstein E.J., Ferrari M.R. (2016) The variability in the amount of homoeologous pairing among $\mathrm{F}_{1}$ hybrids depends on the genotypical constitution of the parental species. AoB Plants 8: plw030.

Poggio L., Realini M.F., Fourastié M.F., García A.M., González G.E. (2014) Genome downsizing and karyotype constancy in diploid and polyploid congeners: a model of genome size variation. AoB Plants 029, https://doi.org/10.1093/aobpla/plu029.

Rayburn A.L., Biradar D.P., Bullock D.G., McMurphy L.M. (1993) Nuclear DNA content in $\mathrm{F}_{1}$-hybrids of maize. Heredity 70: 294300.

RBG Kew Plant DNA C-values database (2017) http://www.kew.org/cvalues.

Realini M.F., Poggio L., Cámara Hernández J., González G.E. (2016) Intra-specific variation in genome size in maize: cytological and phenotypic correlates. AoB Plants 8: plv138.

Schnack B., Covas G. (1945) Hibridación interespecífica en Glandularia (Verbenaceas). Darwiniana 7: 71-79.

Schnack B., Solbrig O.T. (1953). El híbrido G. lacinata $\times$ G. peruviana y su anfiploide artificial. Rev. Fac. Agron. Univ. Nac. La Plata 29: 255-266.

Solbrig O.T., Passani C., Glass R. (1968) Artificial hybridization between different polyploid levels in Glandularia (Verbenaceae). Am. J. Bot. 55: 1235-1239.

Soltis D.E., Soltis P.S., Tate J.A. (2003) Advances in the study of polyploidy since plant speciation. New Phytol. 161: 173-191.

Turner B.L., Powell A.M. (2005) Chromosome numbers of Glandularia (Verbenaceae) from Central and trans-Pecos, Texas. SIDA. Contr. Bot. 21: 1657-1661. 
Umber R.E. (1979) The genus Glandularia (Verbenaceae) in North America. Syst. Bot. 4: 72-102.

\section{ACKNOWLEDGEMENTS}

The authors thank National Council of Scientific Research of Argentina (CONICET), University of Buenos Aires, and University of Lomas de Zamora. This research was carried out in Argentina and supported by grants from the Consejo Nacional de Investigaciones Científicas y Técnicas, Universidad de Buenos Aires and Agencia Nacional de Producción Científica y Tecnológica SECyT. 


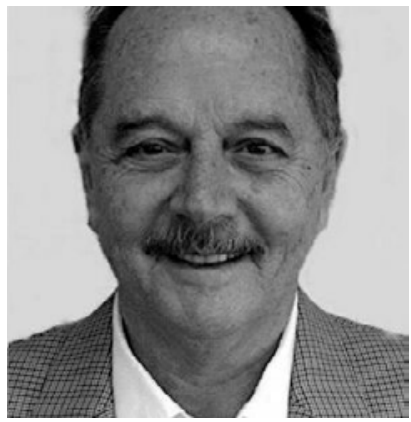

OBITUARY

DR. ROBERTO COCO

Quilmes, Buenos Aires,

$31 / 05 / 1943-26 / 10 / 2019$

Buenos Aires, 6 de noviembre de 2019.

\section{A la memoria del Dr. Roberto Coco}

Confieso que escribir este homenaje póstumo al Dr. Roberto Coco es muy difícil y triste para mí, porque él fue mi maestro y mi amigo. Es a la vez un gran honor que quiero compartir especialmente con mi amiga y fiel colaboradora de Roberto, la Dra. Graciela del Rey, hoy profundamente conmovida como todos, por el vacío que nos deja su ausencia.

Una tarde, hace unas pocas semanas en su casa junto a Irma, su hermana y colaboradora de siempre, me fue relatando con mucha emoción su carrera profesional, sus comienzos, sus desafíos, sus alegrías, sus tristezas y algunos aspectos para mí desconocidos que trataré de compartir con los lectores de este humilde y sentido homenaje. Tal vez él intuía que no podría terminar de escribir sus memorias y así fue, la muerte lo sorprendió el pasado 26 de octubre cuando aún tenía muchos proyectos por cumplir.

Roberto era quilmeño como yo, y amaba profundamente a su querida Quilmes en la que nació el 31 de mayo de 1943. En esa ciudad disfrutó, junto a sus amigos y seres queridos, muchos momentos felices de su vida. Lo recuerdo haciendo deportes y festejando sus cumpleaños en la ribera quilmeña, y pasando sus veranos en el Pejerrey Club, donde siempre me recordaba con humor, sus frustrados intentos para enseñarme a nadar ¡Qué lindas épocas de nuestras vidas!

Siendo muy joven, empezó su trayectoria como tecnólogo en el Departamento de Medicina Radiosanitaria de la Comisión de Energía Atómica (CNEA), mientras estudiaba bioquímica en la Universidad de Buenos Aires y allí comenzó a trabajar en cultivos de linfocitos para estudiar las roturas cromosómicas producidas por radiaciones. Corrían los años de la década de 1960 y recién la Citogenética empezaba en el mundo. Luego no dudó en renunciar a la CNEA para presentarse a un concurso como becario en la "Fundación de Endocrinología Infantil" en el Hospital "Ricardo Gutiérrez" donde, repitiendo sus palabras "Era una oportunidad que no podía desaprovechar" y allí sorprendió, confirmando el diagnóstico presuntivo de una paciente con Síndrome de Turner mediante el estudio citogenético.

Fue un verdadero autodidacta y un pionero de la Citogenética en Argentina. Fue además, miembro fundador de la Sociedad Argentina de Genética y miembro de la Carrera de Personal de Apoyo y posteriormente Investigador Clínico del CONICET. Se perfeccionó en Citogenética en Italia y Francia. Me comentó esa tarde, que estuvo en París donde logró alojarse en la Casa Argentina. Fueron tiempos de aprendizaje en los que su capacidad y su espíritu de lucha lo llevaron a ser reconocido por el Dr. Lejeune, quien lo puso a prueba como a todos los rotantes que por allí pasaban, mostrándole un cariotipo mal armado, en el que descubrió rápidamente los errores.

Se doctoró en la Facultad de Bioquímica y obtuvo el diploma de honor a la mejor "Tesis Doctoral" en 1977. 
Desde aquellos comienzos su carrera nunca dejó de crecer, siendo reconocido en Argentina y en el Mundo. En el Centro de Endocrinología Infantil en el Hospital "Ricardo Gutiérrez", junto a sus queridos colegas y amigos, que lo acompañaron hasta su último día, llegó a ser el Jefe del Laboratorio de Citogenética y formó un grupo de trabajo, del que tuve el placer de formar parte. Fue sin duda la etapa más feliz de mi vida profesional. Éramos jóvenes y él era nuestro maestro y nuestro referente. Nos enseñó con total desinterés, nos guió, y nos trasmitió la pasión por la Citogenética. Lamentablemente ese grupo no pudo continuar bajo su dirección y me confesó que ese año, en el que además murió su papá, fue muy triste para él, porque sufrió la pérdida de ese ser tan querido y la de un grupo de colaboradores que él pensaba tener por mucho más tiempo. Sin embargo, su trabajo no fue en vano, todos seguimos la misma línea y si bien no teníamos su brillantez, nos dejó una impronta que nos acompañó a cada uno de nosotros en nuestra futura vida profesional.

Su espíritu inquieto hizo que no se conformara sólo con la Citogenética como tal, e incursionó en otras áreas, como la "Fertilización in vitro" (FIV), donde también fue un pionero en Argentina, organizando el primer laboratorio de FIV en nuestro país, en el Centro Privado de Medicina y Genética Reproductiva donde se desempeñó como Embriólogo desde los años 1984 a 1987. Posteriormente fue miembro fundador y Director Científico de Fecunditas, Instituto de Medicina Reproductiva afiliado a la Facultad de Medicina de la UBA desde 1989, en el que fue Director del Laboratorio de Genética y FIV y donde desarrolló gran parte de su actividad en ese tema. Por ese lugar pasaron muchos profesionales de aquí y del mundo a realizar rotaciones y múltiples tesis y tesinas y todos lo recuerdan con inmenso cariño y agradecimiento.

Siempre lo admiré, tenía esa conjunción tan poco común de inteligencia, capacidad de trabajo y audacia que lo llevaron a la grandeza, prueba de ello fueron los muchos premios y distinciones que recibió a lo largo de su vasta carrera profesional como el de ser designado Miembro titular de la Academia Nacional de Farmacia y Bioquímica de la UBA y el haber recibido el diploma de honor de "Embriólogo Clínico", el que su penosa enfermedad, le impidió recibir personalmente.

Es imposible mencionar sus múltiples logros y seguramente hubieran sido muchos más, porque Roberto se fue demasiado rápido cuando aún tenía mucho para dar. Nos costará mucho adaptarnos a su pérdida porque ya no tendremos al maestro, al amigo y al docente, siempre dispuesto a dar clases cuando se lo invitaba a participar. Sin embargo, fue tan intensa su trayectoria y tanto el cariño que nos brindó, que como todos los grandes nos deja un legado que perdurará en cada uno de nosotros por siempre y más aún, deja una huella en la historia científica argentina, donde sólo quedan los que han forjado un rumbo y él lo hizo en Citogenética, Fertilización in vitro, Diagnóstico Preimplantatorio, Andrología y Embriología Clínica.

Si tuviera que destacar sus muchas virtudes, destacaría su humildad, su simpleza, la capacidad de acompañar a los amigos en los buenos y malos momentos (lo hizo conmigo cuando fallecieron mis padres), su amor por la familia, se enternecía con sus sobrinitos nietos que lo llenaban de felicidad, amante de la buena música, excelente cocinero y excelente anfitrión. ¡Cómo olvidar las muchas reuniones en su casa, junto a Irma, donde su calidez de siempre hacía que disfrutáramos de muy gratos momentos!

Querido profesor, como yo solía decirle, tu familia, tus amigos, tus colegas y tus discípulos te tendremos siempre en nuestro corazón y espero que tu vida sea un ejemplo a seguir para todos aquellos jóvenes con ilusiones que quieran alcanzar una meta deseada, ya que partiendo de muy abajo y con mucho trabajo y espíritu de lucha llegaste muy alto, siempre enfrentando nuevos desafíos.

Te vamos a extrañar mucho querido Roberto!

Con todo nuestro cariño y todo nuestro agradecimiento.

Marta S. Gallego

PD: Agradezco el aporte que realizó a este homenaje su discípula y amiga la Dra. Clara Rivelis. 


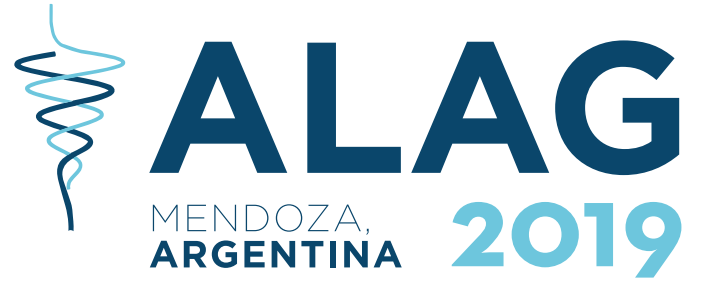

6 AL 9 DE OCTUBRE DE 2019
XVII CONGRESO LATINOAMERICANO DE GENÉTICA XLVII CONGRESO ARGENTINO DE GENÉTICA LII REUNIÓN ANUAL DE LA SOCIEDAD DE GENÉTICA DE CHILE VI CONGRESO DE LA SOCIEDAD URUGUAYA DE GENÉTICA V CONGRESO LATINOAMERICANO DE GENÉTICA HUMANA V SIMPOSIO LATINOAMERICANO DE CITOGENÉTICA Y EVOLUCIÓN

\title{
RESÚMENES OMITIDOS
}

\section{REUNIÓN REGIONAL \\ GENÉTICA Y GENÓMICA DE LA VID. UNA PERSPECTIVA REGIONAL Y MULTISECTORIAL}

\author{
Coordinador: Lijavetzky D.
}

Instituto de Biología Agrícola de Mendoza (IBAM), UNCuyo, CONICET, Facultad de Ciencias Agrarias, Almirante Brown 500, M5528AHB, Chacras de Coria, Mendoza, Argentina.

dlijavetzky@conicet.gov.ar

La vid (Vitis vinifera) es una especie única, no sólo por ser el principal cultivo fruti-hortícola del mundo, sino que también posee una antigua conexión histórica con el desarrollo de la cultura humana. En Sudamérica se ha establecido una viticultura basada en la diversidad de climas y suelos, y en las variedades, verdaderas banderas de producción nacional. Los productores de vino más importantes del subcontinente son Argentina y Chile. Salvo en Uruguay y Brasil, la producción de vino en el resto de países sudamericanos muestra cifras reducidas si se comparan con otros países del mundo con superficie equivalente. Argentina es el país con mayor cantidad de superficie de vid plantada en la región. La región vitícola argentina por excelencia es Mendoza, representando el 70,6\% de la superficie cultivada de vid del país con una producción en el último año de 866 millones de litros de vino (INV, 2016). En los últimos años se han desarrollado proyectos en Uruguay, Chile y Argentina tendientes a descifrar los genomas de las variedades más importantes de cada país, así como para estudiar la variabilidad genética dentro de cada una de ellas. Asimismo, en la provincia de Mendoza, existen empresas del sector vitivinícola desarrollando proyectos tendientes a explotar la mencionada variabilidad. Por lo expuesto, se plantea realizar el presente evento incluyendo simposistas involucrados en los proyectos latinoamericanos y también pertenecientes a dos empresas del sector vitivinícola mendocino (Viveros Mercier Argentina y Bodegas Catena Zapata). 


\section{DECODING THE SECRETS OF MALBEC GENOME \\ BY THE ANALYSIS OF THE CLONAL GENOMIC VARIATION}

Calderón L.', N. Mauri', C. Muñoz', L. Bree ${ }^{3}$, P. Carbonell Bejerano², D. Bergamin ${ }^{3}$, C. Royo ${ }^{2}$, C. Sola ${ }^{3}$, J.M. Martínez Zapater ${ }^{2}$, D. Lijavetzky'. IInstituto de Biología Agrícola de Mendoza (IBAM), CONICET, UNCUyo, FCA, Almirante Brown 500, Chacras de Coria, Mendoza, Argentina; ${ }^{2}$ Instituto de Ciencias de la Vid y del Vino, Consejo Superior de Investigaciones Científicas, Universidad de La Rioja, Gobierno de La Rioja, Logroño, España; ${ }^{3}$ Vivero Mercier Argentina, Ruta 40 sur km 3273, 5509 Perdriel, Luján de Cuyo, Mendoza, Argentina.

dlijavetzky@conicet.gov.ar

Somatic mutations are a major force introducing novel genetic variation; this role becomes enhanced in systems lacking sexual reproduction. This is the case of grapevines used in the wine industry. Here, clonal propagation through asexual cuttings is the regular practice, in order to preserve quality traits of productive relevance. Nonetheless, a remarkable phenotypic variation has been reported among clones within cultivars. However, less is known about the intracultivar genetic variability and its potential impact on the phenotype. We characterize the clonal genetic variability of Vitis vinifera L. cv. Malbec, which is the main cultivar for Argentine viticulture. We performed a genome wide analysis of four Malbec clones, obtaining Illumina reads at a 35x depth for each clone. Bioinformatic tools were employed to align our sequences to the reference genome (genotype PN40024). We implemented variant calling pipelines for single nucleotide variations (SNVs) discovery, and applied strict quality filters to determine a set of reliable SNVs. We discovered ca. 2.6 million SNPs that distinguish cv. Malbec from the reference genome, and identified 458 SNVs explaining the genetic variation between the four Malbec genotypes, including 421 clonespecific SNVs. Using that information, we developed a Malbec "Fluidigm" SNP chip that allowed us to found a notorious genetic variability in a large clone collection, as a consequence of somatic mutations accumulation.

\section{BÚSQUEDA DE GENES Y MARCADORES ASOCIADOS A TAMAÑO DE BAYA EN VID DE MESA, CARÁCTER CUANTITATIVO Y COMPLEJO}

Muñoz Espinoza C.', G. Ravest', M. Burgos', P. Jiménez', S. Bustos', M.H. Castro', P. Hinrichsen'. 'INIA La Platina, Chile.

phinrichsen@inia.cl

La domesticación de la vid ocurrió paralelamente en el Cáucaso y en Europa central, seleccionándose simpátricamente dos tipos bien diferentes: vides de vinificación y de consumo fresco. Este proceso originó dos genomas y fenotipos con importantes diferencias. Una de estas características es el tamaño de la baya, deseable más grande en uva de mesa. Por esta razón, este carácter ha sido priorizado por nuestro grupo en la búsqueda de marcadores que sean de utilidad en el desarrollo de nuevas variedades. En este simposio se presentarán los avances logrados en este tema, incluyendo también resultados del estudio de la vía metabólica de las giberelinas, por su alta incidencia en este carácter. Combinando análisis fenotípicos genéticos, transcriptómicos y de expresión génica, se identificó un conjunto de 38 polimorfismos de tipo SNPs e InDels asociados a este carácter altamente cuantitativo, relacionados a un número similar de genes candidatos; un subconjunto de estos marcadores fue capaz de predecir un porcentaje sustancial de la variación del carácter. Dado que su uso en selección asistida es técnicamente difícil de implementar, recientemente se han analizado más de 300 marcadores SSR en las mismas regiones cromosómicas (FONDECYT 1171378). También se han considerado SSRs cercanos a genes tipo factores de transcripción asociados a tamaño de baya en cepas de vino. Algunos de estos SSRs presentan variantes alélicas con una considerable asociación con tamaño de baya y están en etapa de validación en diferentes fondos genéticos para su uso en selección (o descarte) de nuevas líneas. 


\section{EL GENOMA DE TANNAT: HERRAMIENTAS ÓMICAS AL SERVICIO DE LA VITIVINICULTURA URUGUAYA}

Da Silva C., A. Ferrarini², E. Boido ${ }^{3}$, C. Gaggero ${ }^{4}$, M. Delledonne ${ }^{2}$, F. Carrau ${ }^{3}$. IPDU Espacio de Biología Vegetal del Noreste, Centro Universitario de Tacuarembó, Universidad de la República, Uruguay; ${ }^{2}$ Centro di Genomica Funzionale, Dipartimento di Biotecnologie, Universitá degli Studi di Verona, Italia; ${ }^{3}$ Área Enología y Biotecnología de Fermentación, Facultad de Química, Universidad de la República, Uruguay; ${ }^{4}$ Departamento de Biología Molecular, Instituto de Investigaciones Biológicas Clemente Estable, Uruguay.

dasilvacece@gmail.com

Tannat (Vitis vinifera) es la variedad de vid vinífera más cultivada en Uruguay para la producción de vinos tintos de alta calidad. Sus bayas poseen niveles de compuestos polifenólicos (antocianinas y taninos) inusualmente altos, produciendo vinos con intenso color púrpura y alto poder antioxidante. Pero es considerada una variedad no aromática. Los taninos dan estructura en boca a los vinos, se sintetizan en las semillas antes de envero y en Tannat más de un 40\% están galoileados, lo que determina un mayor poder antioxidante. Las antocianinas dan color a la piel de las uvas y al vino y su síntesis comienza durante el envero. Secuenciamos el genoma de Tannat con una profundidad de 134X. Secuenciamos trancriptomas de cáscaras y semillas a lo largo del desarrollo de la baya. El objetivo es dilucidar las bases genómicas y transcriptómicas de las particularidades de Tannat. Al comparar su genoma con el de Pinot Noir (genoma de referencia) encontramos una expansión de las familias génicas relacionadas con la biosíntesis de polifenoles. Análisis de los patrones de expresión diferencial asociados a estudios metabolómicos (HPLCMS) nos permitieron asignar funciones a genes antes desconocidas; y la participación de genes nuevos (no anotados previamente en el genoma de referencia) y varietales (ausentes en el genoma de referencia) en la biosíntesis de los polifenoles característicos de Tannat. Nuestros trabajos realizan aportes originales acerca de las bases moleculares de la biosíntesis de antocianinas y taninos durante el desarrollo de la uva vinífera insignia del Uruguay.

\section{SELECCIONES MASALES Y CLONALES DE MALBEC EN ARGENTINA}

Sola C..' 'Vivero Mercier Argentina S.A.

cjdsola@yahoo.com.ar

En la década de 1990 quedaban en Argentina apenas 10.000 has de viñedos "resilientes" de la variedad Malbec, casi todas en Mendoza. Este viñedo vino a constituirse en el principal reservorio genético de esta variedad. Trabajamos en la obtención de selecciones masales, a partir de viñedos de calidad reconocida, en los que se eligieron plantas sanas, de identidad indubitable, identificando caracteres fenotípicos, asociados a atributos cualitativos en los vinos. No buscamos el Malbec "perfecto", ya habíamos aprendido que en la diversidad encontraríamos el acervo genético que necesitábamos. Seleccionamos plantas por la intensidad de color del raquis, pedicelo y bayas, otros por el buen llenado de racimos, sin signos de corrimiento, cantidad de semillas en la baya, grosor de las pieles, otros por la forma, tamaño y color de las hojas,o más de un carácter a la vez. Para avanzar en lo referente a la productividad se requería un salto cualitativo. Siguiendo el modelo europeo, comenzamos la selección clonal, lo que permitió mejorar notablemente el estado sanitario y elegir plantas con una historia constante. Con las primeras vendimias se realizaron las microvinificaciones, con exhaustivos estudios agronómicos $\mathrm{y}$ análisis fisicoquímicos de uvas y vinos, testeo con representantes de la industria, y lanzamiento al mercado de los primeros clones de Malbec obtenidos de viñedos "autóctonos". Entre los más destacados se encuentran los clones M136, M502, M505, M506, M512 y M713. 


\section{MALBEC ARGENTINO: CIENCIA AL SERVICIO DE LA DIVERSIDAD GENÉTICA}

Alonso R.', F. Buscema'. 'Catena Institute of Wine.

ralonso@catenainstitute.com

En Argentina, Malbec (Vitis vinifera L.) ha tenido una excelente adaptación a nuestros terruños, lo cual ha posibilitado una gran calidad enológica. A su vez, por diversas razones, Argentina se ha quedado con gran parte de la variabilidad genética de este cepaje. A partir de la década de 1980, debido a una fuerte reducción de la superficie implantada, organismos oficiales iniciaron planes de selección con el objetivo de sólo mejorar la productividad y sanidad. Por ello, en 1995 Catena Zapata a través del Catena Institute of Wine implanta una selección clonal sobre la cual realiza estudios no sólo tendientes a incrementar la calidad enológica, sino también a conocer la diversidad del material genético. Se implantaron más de 130 clones de Malbec en dos regiones vitícolas, climáticamente muy distintas. En uno de los primeros trabajos se determinó el perfil de antocianos de las bayas y a partir de esta información se logró diferenciar clones individuales y luego agruparlos de acuerdo a la presencia de perfiles similares. En otro estudio, encontramos marcadas diferencias entre clones argentinos y clones franceses, en cuanto a rendimiento y perfil polifenólico. Actualmente estamos evaluando el rol de mecanismos epigenéticos en la plasticidad fenotípica con la finalidad de ampliar los conocimientos sobre la aclimatación a distintos ambientes. Este mayor entendimiento logrado con las investigaciones, nos ha permitido mejorar la calidad del vino, y a su vez es la base para prepararnos ante los futuros escenarios ambientales producto del cambio climático global. 
Lorenzo C.D., P. Garcia Gagliardi, M. Hoijemberg, P. Cerdan. Fundación Instituto Leloir.

E-mail: clorenzo@leloir.org.ar

Shade intolerant plants respond to a reduction in the red (R) to far-red light (FR) ratio (R:FR) by elongating stems and petioles, re-positioning leaves and accelerating flowering. These strategies are known collectively as the shade avoidance syndrome (SAS). As of date, not much is known about the physiological and molecular mechanisms of SAS in alfalfa (Medicago sativa), an important perennial forage species. Therefore, we exposed alfalfa plants to simulated shade to analyze morphological changes, coupled with a RNA sequencing analysis to study genes involved in SAS. For RNA seq, two samples were analyzed for both conditions, each comprised of two leaves belonging to independent plants. For statistics analysis Edge $\mathrm{R}$ was used for $\mathrm{p}$-value and false discovery rate (FDR) correction. Low R:FR produced a classical SAS, such as increased internode, petiole length and reduced chlorophyll biosynthesis. On the contrary to most shade intolerant species, flowering onset was delayed. In terms of genes involved, the SAS was likely mediated by upregulation of msPIF3 and msHB2 in low R:FR, whose constitutive expression in Arabidopsis thaliana led to a complete SAS phenotype. On the other hand, delayed flowering was likely to be mediated by downregulation of msSPL3.We propose that shade-delayed flowering in alfalfa may be an important response to extend the vegetative phase under sub-optimal light conditions and thus assure an accumulation of reserves to resume growth after the next season. 


\section{MODIFICACIONES SOLICITADAS POR LOS AUTORES EN RESÚMENES PUBLICADOS}

\author{
$\mathrm{CH} 2$ (p. 97) \\ REPORTE DE UN CASO DE DIAGNÓSTICO \\ PRENATAL DE TRISOMÍA PARCIAL 3Q22.2-> 3 QTER, \\ MONOSOMÍA PARCIAL 11Q25- > 11 QTER Y DELECIÓN \\ INTERSTICIAL 10Q25.1-10Q25.2 POR CITOGENÉTICA \\ Y MICROARRAY
}

María Cecilia Della Vedova ${ }^{1,2,4}$, Susana Siewert ${ }^{2}$, Noelia Federica Barrasa $^{3}$, Ralph Bravo ${ }^{3}$, Doris Lozada ${ }^{3}$, Pilar Igarreta ${ }^{5}$ y Silvana Mariel Marsá ${ }^{2,4}$.Instituto de Química de San Luis (INQUISAL). Consejo Nacional de Investigaciones Científicas y Técnicas (CONICET); 2Universidad Nacional de San Luis. San Luis, 5700 San Luis, Argentina; ${ }^{3}$ Maternidad Provincial Dra. Teresita Baigorria. San Luis, 5700, San Luis, Argentina; ${ }^{4}$ Laboratorio Privado de Genética -Genes. San Luis, 5700, San Luis, Argentina; ${ }^{5}$ Laboratorio Genda, Buenos Aires, Argentina.

\section{FG 5 (p.127) \\ VARIANTES GÉNICAS VINCULADAS CON \\ LA TOXICIDAD POR 6-MERCAPTOPURINA \\ EN PACIENTES URUGUAYOS CON \\ LEUCEMIA LINFOBLÁSTICA AGUDA}

Burgueño Rodríguez G.', D. Malimpensa², J.A. Da Luz', A.M. Soler?. 'Laboratorio de Genética Molecular Humana, CENUR Litoral Norte - Sede Salto, Universidad de la República (UdelaR), Salto, Uruguay; ${ }^{2}$ Laboratório de Hemoglobinopatías Hereditárias, Departamento de Patología Clínica, Faculdade de Ciências Médicas, Universidade Estadual de Campinas (UNICAMP), Campinas, SP, Brasil.

anamasoler@gmail.com

La leucemia linfoblástica aguda (LLA) comprende casi el $30 \%$ de los cánceres pediátricos. Cerca del $80 \%$ de los pacientes atendidos en el Servicio de HematoOncología Pediátrica del Centro Hospitalario Pereira Rossell alcanzan una remisión completa. El tratamiento consiste en la administración simultánea de diversos fármacos durante dos años. Sin embargo, el estrecho rango terapéutico y la acción inespecífica de estos fármacos favorecen la aparición de efectos adversos. Nueve variantes en los genes TPMT y NUDT15 explican cerca del $40 \%$ de las toxicidades hematológicas en la fase de mantenimiento de la terapia. El objetivo de este trabajo es identificar otras variantes genéticas involucradas en la toxicidad hematológica debido a 6-mercaptopurina (6-MP) en niños con LLA. Para ello, se secuenciaron los exones de los genes TPMT y NUDT15 y se analizaron variantes en los genes ITPA, ABCC4 y PACSIN2, en pacientes con toxicidad hematológica. Datos preliminares indican que en pacientes sin variantes en los genes TPMT y NUDT15, la presencia de la variante ITPA $196(C \rightarrow A)$ está asociada a un número significativamente menor de eventos de leucopenia. Por otro lado, los pacientes con la variante rs11568658 (ABCC4) resistieron dosis significativamente menores que aquellos que no la presentan. Adicionalmente, identificamos una nueva mutación (E570) en el gen NUDT15, que posiblemente altere la función de la proteína. Estos resultados revelan la importancia de las variantes genéticas en la toxicidad por 6-MP y su posible importancia en otras fases del tratamiento.

\section{GH 35 (p. 196) \\ INFERFERÓN LAMBDA 4 (INFL4) Y RESISTENCIA A LA INFECCIÓN POR VIH-1}

Jaimes-Bernal C.P.,2 N. Rallón ${ }^{3,4}$, J.M. Benito ${ }^{3,4}$, O. Mohamed ${ }^{5}$, M.A Gómez-Vidal5 ${ }^{5}$, F.J. Márquez², B. Sánchez-Arcas ${ }^{2}$, M. Trujillo6, J.L. Royo7, I. Saulle ${ }^{8}$, M. Biasin' ${ }^{8}$ A. Rivero-Juárez ${ }^{9}$, A. Caruz². 'Grupo de investigación del programa de Bacteriología y laboratorio clínico, Universidad de Boyacá, Tunja, Colombia; ${ }^{2}$ Unidad de Inmunogenética. Departamento de Biología Experimental, Universidad de Jaén.; ${ }^{3}$ Instituto de Investigación Sanitaria-Fundación Jiménez Díaz, Universidad Autónoma de Madrid (IIS-FJD, UAM), Madrid, España; ${ }^{4} \mathrm{Hospital}$ Universitario Rey Juan Carlos, Móstoles, Madrid,España; ${ }^{5}$ Complejo Hospitalario de Jaén, España; ${ }^{6}$ Centro Transfusional de Sangre, Jaén, España; ${ }^{7}$ Departamento de Bioquímica, Biología molecular e Inmunología, Universidad de Málaga, España; ${ }^{8}$ Universidad de Milán, Italia; ${ }^{9}$ Hospital Universitario Reina Sofía, Córdoba, España. cpjaimes@ uniboyaca.edu.co

MCTA 13 (р. 335)

IMPLEMENTACIÓN DEL ANÁLISIS DE

MICRONÚCLEOS CITOMA BUCAL

EN BOVINOS TRATADOS CON LOS

ANTIPARASITARIOS EXTERNOS CLORPIRIFOS Y CIPERMETRINA+CLORPIRIFOS

Daniela M Ferrél,2, Rocío T Carracedo', Brenda Lucero', Rocío Heredia', Héctor R Ludueña', Nora B M Gorla ${ }^{1,2}$. 'Laboratorio de Genética, Ambiente y Reproducción, Universidad Juan Agustín Maza; ${ }^{2}$ CONICET.

MCTA 14 (р. 335)

ENSAYO EX VIVO DE MICRONÚCLEOS CITOMA CON BLOQUEO DE LA CITOCINESIS PARA EVALUAR GENOTOXICIDAD DE LA MEZCLA CIPERMETRINA+CLORPIRIFOS EN BOVINOS

Daniela M Ferré1,2, Brenda Lucero', Rocío T Carracedo', Rocío Heredia', Valeria Lentini', Raquel R Romano', Héctor R Ludueña', Nora B M Gorla',2. 'Laboratorio de Genética, Ambiente y Reproducción, Universidad Juan Agustín Maza; ${ }^{2}$ CONICET. 


in

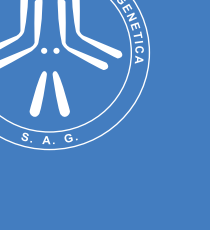

